
$\therefore$
$=1$
$\vdots 1$
$\therefore \quad 5$ 



\section{THE HISTORY OF}

\section{LIQUOR LICENSING IN ENGLAND}

PRINCIPALLY FROII 1700 TO 1830 



\section{THE HISTORY OF LIQUOR}

\section{LICENSING IN ENGLAND}

\section{PRINCIPALLY FROM 1700}

\section{TO 1830}

SIDNEY AND BEATRICE WEBB

LONGMANS, GREEN AND CO., 39 PATERNOSTER ROW, LONDON, NEW YORK \& BOMBAY. OCT. 1903. 



\section{3}

\section{PREFACE}

IT is needful to preface this little book with ${ }_{\mathrm{G}}$ an explanation. Four years ago we began 鼻 an elaborate investigation into English Local Government during the eighteenth and nineteenth centuries. Our task quickly divided itself into two parts. We had first to discover the structure of local government, to unravel and describe the exact constitution and working $\checkmark$ all over the country of the Open and Select Vestries, the Manorial Courts, the Commissioners of Sewers, the various kinds of statutory bodies established under special Acts, the County Justices in Petty and Quarter Sessions, and the Municipal Corporations. We had then to classify local government according to function, and to क्ष treat, one by one, such different public services as the Relief of Destitution, the Prevention of Crime, the Cleaning and Paving of Streets, the 


\section{vi LIQUOR LICENSING IN ENGLAND}

Regulation of Trade, the Maintenance of Churches, Harbours, Docks, Roads, and Bridges, and the raising of a municipal revenue by duties and tolls, rates and assessments. The results of this investigation into both structure and function, for the period up to the reforms of 1832-35, we hope to publish in the course of 1904 . Meanwhile it has been suggested to us that our chapter on the Regulation of the Liquor Traffic, especially its hitherto unknown episode of 178687, with the dramatic suppression of licensed houses without compensation, might be specially instructive at this juncture, and that it may interest readers who would not care to study the whole range of English Local Government. The drawbacks of separate publication are considerable. In the course of our narrative we have constantly referred to contemporary facts dealt with in other chapters, such, for instance, as the diversity in character and procedure of the different benches of Justices of the Peace in urban and rural districts, in London and the municipal corporations. These facts will not necessarily be known to the general reader. Moreover, for students mainly interested in the 
modern controversy, a mere shred of history cut out of its context, beginning at 1700 , and ending abruptly at 1830 , cannot provide satisfactory reading. The first of these drawbacks we have sought to meet by appending many footnotes to the text. The second we have tried to diminish, by prefixing a short historical introduction, and appending a summary of licensing legislation since 1830, drawn from obvious sources.

With this explanation of some of its imperfections, we offer the following sketch of what did happen between 1700 and 1830, as possibly contributing towards an understanding of the present problem. We carefully abstain from pointing any moral or drawing any conclusions as to present day policy.

We must add that we are indebted for the fulness of detail and richness of variety in our work to our two zealous and able assistants and colleagues, Mr. F. H. Spencer, and Miss Amy Harrison, B.A., D.Sc. (now Mrs. Spencer). Nor would the work have been possible but for the treasures of the British Museum, and, in particular, its invaluable col- 
viii LIQUOR LICENSING IN ENGLAND

lection of old provincial newspapers, which it was, at one time, actually proposed to disperse! We venture to express our strongest hopes that whatever else is sent away, these files of old provincial newspapers-without which the social history of England cannot possibly be writtenwill be kept at Bloomsbury, where they are accessible to the historical student, and where (as it is privately admitted) there is ample accommodation for them.

\section{SIDNEY AND BEATRICE WEBB.}

41 Grosienoli hoAD, WestMinster,

Srptrmber 1903. 


\section{CONTENTS}

\section{CHAPTER I}

PAGE

The First Century of Licensing . . . . . . 1

\section{CHAPTER II}

A Period of Laxness . . . . . . . . . 15

\section{CHAP'TER III}

Regulation and Suppression $\quad . \quad$. $\quad . \quad . \quad . \quad$. 49

\section{CHAPTER IV}

Free Trade in Theorx and Practice . . . . 85

\section{CHAPTER V}

Legislative Repextance • • • • • • • . 127

\section{APPENDIX}

The Movement for the Reformation of Manners . . 137

INDEX $\quad . \quad$. $\quad . \quad . \quad . \quad . \quad 153$ ix 



\section{CHAPTER I}

THE FIRST CENTURY OF LICENSING

WE have made no study of the numerous instances of manorial or municipal regulation of the liquor traffic in England prior to the sixteenth century. It is easy to find, in such scanty records of the fourteenth and fifteenth centuries as are yet printed, curiously exact precedents, in one town or manor or another, at one period or another, for almost every modern expedient of dealing with the liquor traffic. ${ }^{1}$ Nor can we pretend to have made any systematic investigation into the working of the legislation of the sixteenth century. But in

I Some of these are given, together with a good account of licensing history down to 1642 , in the article, "Early Stages of English Publie House Regulation," by Miss C. M. Iles, of the London School of Economics and Political Science, in the Economic Journal for June 1903. For examples of enforeement of the liquor regulations of the manorial Court froll 1415 onwards see Fulham Old and New, by C. J. Féret (1900), vol. i. pp. 25-26; and the Manchester Court Leet Records. 
order to enable the history of the eighteenth century to be understood, we shall give a brief outline of the course of events during the preceding century and a half.

The regulation of the trade in alcoholic liquors originated, not in any abstract theory, but in a practical necessity of the State. It was found that the free use of intoxicating drinks produced not only incapacity and disease among all classes, but also, among the "lower orders," idleness and disorderly living, crimes against life and property, and even riot and rebellion. Total prohibition of the production and sale of intoxicants was, in face of the ease of manufacture and the absence of police, plainly impracticable. Moreover, beer, at any rate, was universally regarded as a necessity of life; it was the common beverage at every meal; and all but a small minority of the population habitually enjoyed drinking. On the other hand, the evils of excessive drinking were so manifest and so widespread, that the Government, in every generation, has felt compelled to do something more than punish the crimes which drunkenness produces. For more than three hundred years the manufacture and sale of alcoholic drinks has been brought under special statutory regulation. The primary object of this legislation ${ }_{\alpha}$ has been 


\section{FIRST CENTURY OF LICENSING}

to prevent the social disorder and personal misconduct brought about by excessive drinking; and the legislators have sought to place obstacles to the unrestricted sale of intoxicants to individuals. But this main purpose has been, from time to time, complicated and thwarted by two material considerations: the discovery, made by successive governments, that taxes on alcoholic drinks provided an easy and copious source of revenue, and the desire to promote the extensive native industries of brewing and distilling. Under the influence of these diverse and often conflicting motives, the regulation of the liquor traffic has, in England, been shared between the central executive and the local authorities. The national Government has always taken for itself the revenue to be derived from alcohol, whether in the form of royal patents, excise duties on the manufacture, custom duties on the imports, or revenue licences of the dealers. We might omit all reference to these national taxes, and to the extensive system of official control devised for their protection, as forming no part of English local government. On the other hand, the duty of regulating the consumption of alcoholic drinks in such a way as to obviate social disorder has always been left to the local authorities, and we shall find it 
impossible, in describing their exercise of this function, to avoid mentioning the action of the national Government, when, in the pursuit of revenue or for other reasons, its regulations interfered with, and even ousted, the powers of Justices of the Peace.

The device of licensing-that is, the requirement that any person desiring to pursue a particular occupation shall first obtain specific permission from a governing authority - may be used to attain many different ends. The licence may be merely an occasion for extracting a fee or levying a tax. It may be an instrument for registering all those who are following a particular occupation, in order, for some reason or another, to ensure their being brought under public notice. It may be a device for limiting the numbers of those so engaged, or for selecting them according to their possession of certain qualifications. Finally, the act of licensing may be the means of imposing special rules upon the occupation, or of more easily enforcing the fulfilment either of these special rules or of the general law of the land.

The function of licensing, as it has been delegated by Parliament to the Justices of the Peace, has always included three distinct forms of control: the power of selection, the power 


\section{of withdrawal, and the power of imposing} conditions.

By the statute of 5 and 6 Edward VI. c. 25 (1552) the Justices of the Peace were authorised to select from time to time, at their discretion, certain persons in each county or borough who were alone to exercise the trade of keeping a common alehouse. ${ }^{1}$ From this time forth, the occupation became an exceptional privilege, to which no person could assert a right. ${ }^{2}$ The Justices had full discretion as to the persons whom they would license, a discretion which Parliament limited only by certain insignificant requirements. ${ }^{3}$ What was of importance was

1 There has always been a distinction between an inn which lodges and entertains travellers, and a common alehouse which sells ale to all-comers. Originally an inn (Dalton, c. 56 ; Blackerby, 170) or a lodging-house (Parker and Flint, 1699, 12 Mod. 254), even if it supplied ale to its lodgers, required no licence. An inn might, by common law, be indicted as a public nuisance, if it was improperly conducted, or even if it was set up where it was not needed (1 Haw. 225). But, as inns practically always supplied ale to all-comers, they were quickly brought under the operation of the requirement to obtain licences as common alehouses and their regulation by way of indictment became obsolete.

${ }^{2}$ In 1604 the King pointed out in a Privy Council circular letter that, "By the law and statutes of this our realm, the keeping of alehouses and victualling houses is none of those trades which it is free and lawful for any subject to set up and exercise, but inhibited to all save such as are thereto licensed."

${ }^{3}$ Prior to 1729 the licence might be granted at any time by any two Justices, but by 2 George II. c. 28 (1729) the well-known "Brewster Sessions" was instituted, all licences having to be granted at a general sessions of the Justices of the division, of which one was to be held for this pur lose in September of each year. 
the fact that Parliament, from the outset, implied ${ }^{1}$ that the number of licences was to be kept down to just enough for the supply of the legitimate wants of each neighbourhood, thus creating a sort of monopoly. Moreover, there was no idea of selling this monopoly to the highest bidder, and the Justices were, in fact, required to issue their licence without charge. The result was that the Justices had it in their power to create a valuable property, and to give it to whom they chose.

The power of withdrawing the permission to sell intoxicating liquors is, curiously enough, older than the power to select the sellers. By 11 Henry VII. c. 2 (1495), strengthened by 19 Henry VII. c. 12 (1504), as part of the policy of discouraging indoor games, which diverted the people from archery, any two Justices were authorised summarily to suppress useless alehouses in their neighbourhood," and it was primarily to strengthen this power "to reject and put away common ale-selling in the towns and places where they should think convenient" as they thought meet and convenient, in order

1 Thus, the reason for the institution of special "Brewster Sessions" was so that licences night not be granted " by Justices who, living remote from the places of abole" of the applieants, "may not be truly informed as to the occasion or want of steh inns or common alehouses" (2 George II. e. 28, 1729).

2 History of T'uxes and Taxation, ly S. Dowell (1888), vol. iv. p.91. 
to prevent " the intolerable hurts and troubles to the commonwealth of the realm, daily growing and increasing," that the first licensing Act of 1552 was passed. With the same object, these alehouse licences were required by the Justices to be renewed annually, so that a mere refusal to renew amounted to, and apparently superseded, the statutory power of suppression." The full power of the Justices to refuse the renewal of a licence, entirely at their own discretion, and without assigning cause, was questioned, from time to time, but has always been upheld by the superior courts. The reason for refusal in the Justices' minds might be some misconduct of the publican, or it might be merely that they had come to the conclusion that the number of licences in the neighbourhood was greater than the existing needs warranted. Thus, just as the magistrates could create valuable property, and

1 The term for which the permission or licence of the Justices should be granted was not specified by 5 and 6 Edward VI. c. 25 (1552), but before the end of the sixteenth century it seems to have become customary for Justices to give the licence for one year only (see a form of 1591 in West's Symbolctography, 1606). A royal proclamation of 1618 definitely Irescribed a form of licence for one year, and this seems to have been universaliy adopted. The ammul renewal was implicitly required by 9 Anne e. 16 (1711), inıposing an annual stamp duty, but it was not explicitly made requisite by statute until 26 George II. c. 31 (1753). See Mr. Bonham Carter's evidence before the Royal Commission on Liquor Licensing, 1897.99, and his valuable historical memorandum, in vol. iii. of the Procecdings of this Conmission. 
freely endow any individual with it, so they could, at any "brewster sessions," arbitrarily destroy the property that they lad created, and deprive the holder of it without compensation. ${ }^{1}$

The power of imposing conditions on the licensees was not expressly conferred by statute but really flowed from the coexistence of the powers of selection and withdrawal. Parliament, whilst repeating that there was to be no tippling or disorder, had failed to prescribe under what accompaniments in the way of accommodation or recreation the sale of liquor should be conducted. Right down to the end of the period

1 The Judges always refused to issue a mandamus to the Justices to graut a licence, even on affidavit of their having maliciously or corruptly refused it (Strange, 881; 1 Barnardiston, 402). The superior courts showed, in fact, great reluctance to question the Justices' discretion in the matter. But "if it clearly appears," said Lord Mansfield in 1758, "that the Justices have been partially, maliciously, or corruptly influenced in the exercise of their discretion, and have consequently abused the trust reposed in them, they are liable to prosecution by indictment or information " (R. $v$. Young and Pitts, Burr. Mausf. 556). In 1765 two Justices of the tiny borough of Corfe Castle were committed to prison for a montl, and fined $£ 50$ each, for refusing an alchouse licence to an innkeeper, merely becanse he had voted for a candidate for Parliament whom they were opposing (R. v. Hann and Price, Burr. Mansf. 1716, 1786). Such eriminal proceedings were rare, and convictions still rarer, though we hear of Justices refusing licences to any lersons who petitioned for a workhouse; and there can be no doubt that lieences were frequently restricted, in practice to adherents of the dominant sect or political party. The full diseretion of the Justiees was upheld by the House of Lords in Sharp $v$. Wakefield; see the judgment reprinted in vol. ix. of the Procealings of the Royal C'ommission on Liquor Licensiny, 1897-99. 
that we have under review, Parliament abstained from fixing the hours of opening and closing, on week-days and Sundays, or prescribing the conditions under which the sale of liquor should take place, contenting itself always with the arbitrary control of the Justices, on the one hand, and the profit which the Exchequer derived from the exaction of excise and licence duties on the other. ${ }^{1}$ Thus, it was open to the Justices at any particular time or place to make it known that they would not license the sale of liquor in premises remote from public observation, or inadequate in accommodation for the customers; that they did not approve of music or dancing or other entertainments on licensed premises; that they insisted on the premises being closed at nine o'clock in the evening; and, in fact, to make the renewal of the licence virtually conditional on compliance with any requirement connected with the conduct of the trade that they might think fit to impose.

That the Act of 1552 was carried out by the

1 The earliest statute (11 Henry VII. c. 2, 1495) had empowered any two Justices "to take sureties of keepers of alehouses in their good behaving." These had developed by 1618 into elaborate recognisances, in which were inserted many specific conditions imposed by the Justices, and prescribed by the royal proclamation of that year. After the Revolution these recognisances became much shorter and simpler, confined usually to a merely formal undertaking not to infringe the statute law against tippling, illegal games, ctc. 
Justices is shown by the frequent references to it in the annals both of counties and corporate towns. ${ }^{1}$ From 1587 to 1631 their administration, in this as in other branches of local government, was quickened and kept up to the mark by the series of "Books of Orders," issued by the Privy Council, which formed so important a feature of the administrative system of the time. ${ }^{2}$ That unnecessary alehouses were to be suppressed was constantly enjoined upon the Justices, and it is clear that drastic, and often arbitrary action was taken. The "pulling down of the sign" of an alehouse, summarily suppressed by a choleric Justice of the Peace, is more than once mentioned in contemporary literature. ${ }^{3}$

In 1599, 1604, and 1608, the Justices were

1 See, for instance, the Niddlesex County Records, by J. C. Jeaffreson (1888-92); Sessions Rolls of the North Riding of Yorkshire; West Riding Sessions Rolls (1888); Worcester County Records; Three Centuries of Derlyshire Annals, by J. C. Cox (1890); Annals of Ipswich, by Nathaniel Bacon (1654, see edition of 1884).

2 For an admirable aceount of this attempt to establish a centrally supervised and efhicient administrative system, see The Early History of the English Poor Lau, by Miss E. M. Leonard (Cambridge, 1900).

${ }^{3}$ The withdrawal of the licence was accompanied by the removal of the sign by the prish constable.

\footnotetext{
For this gross fault I here do damn thy licence,

Forbidling thee ever to tap or draw, For instantly I will in mine own person Command the constables to gull down thy sign.
}

Massinger, A New Wray to Puy Old Debts, iv. 2, quoted in The History of Sign-boards, by J. Larwood and J. C. Hotten (1884), p. 11. 
specially enjoined to be careful in granting licences for "the keeping of alehouses and victualling houses . . . which," said the Privy Council in 1604, "ought to be no more than a number competent for the receipt of travellers, and for the supply of wants to poor people not able to provide for any quantity of victual for themselves (which are the true, ancient, and natural use of these houses), and with this also, that they be not made the receptacle of drunkards, felons, and loose and idle persons." I That the Justices at this period took some trouble in the matter is shown by the "articles" which Dalton tells us they drew up in some counties, and forced the alehouse-keepers to agree to, fixing the hours of closing at night, providing for complete Sunday closing, except as regards travellers, and forbidding any tippler to remain more than one hour. ${ }^{2}$

We give one out of the many cases in which alehouses were suppressed simply as being un-

1 Privy Council Cireular Letter to Nayor's and Justices, 1604; given in History of Southampton, by J. S. Davies (1883), p. 278.

${ }^{2}$ See the form of licence to keep an alehouse, and that termed "a condition for alehouse-keepers" (The Countrey Justice, by Michael Dalton (1618), p. 334-336). These "conditions" contained in some cases an interesting anticipation of the "black-list" of 1902: "Nor willingly admit or receive . . a any person . . . that shall be beforehand notified to him, the said $A$. B. by the constable of $M$. or by his deputy, to be an unmeet person to be received into a common alehouse." 
necessary. The Mayor and aldermen of Ripon (Yorks) report to the Privy Council in 1623 that, in pursuance of the directions received, they have made inquiry as to the number of alehouses in the town, and "finding the number to be great, we have reduced them to half the number." 1

In 1618 a royal proclamation recited many of the conditions imposed by Justices, definitely prescribed the form of the licence, and directed that it should be for one year only. It was part of the business of the Judges of assize on their circuits to inquire if the directions of the Privy Council had been duly carried out by the Justices, and the manuscript circuit records show that this administrative supervision of the local authorities was, during the first half of the seventeenth century, frequently made effective by peremptory orders by the Judges. ${ }^{2}$

1 Calendar of State Papers, Domestic, James 1., vol. exxxvii.; Chapters in the History of Yorkshire, by J. J. Cartwright (Wakefield, 1872), pp. 289, 290.

2 Thus, to give one ont of many instances, the MS. Order Book of the Western Cireuit contains, under 13th August 1646, the following order made at the Dorehester Assizes:- "Upon the great complaint of the gentlemen of the Grand Inquest of this county, made to this Conrt at this present assizes, against the multiplieity of alehouses within this county, and the daily abuses and disorders vext and suffered in such alehouses, espreeially on the Sabbath days, whereby the serviee of Almighty God is nuch hindered; for reforming whereof this Court doth think and declare that the .Justices of the Peace within the several divisions and liberties of this county, 


\section{FIRST CENTURY OF LICENSING 13}

\section{The supervision of the Privy Council, by}

which the Justices had been kept up to the mark, was suddenly broken by the outbreak of the Civil War. We do not find that any serious attempt was made, either during the Protectorate or after the Restoration, to reconstruct the centrally supervised administrative system at which the statesmen of Elizabeth and James I. had evidently aimed. The Privy Council orders cease. The Judges of assize gradually abandon

shall, with all convenient speed, inform themselves by the best ways and means that possibly they can, concerning the said abuses committed and suffered by such alehonse-keepers, and not to suffer or license any to sell ale or heer but such as can bring their certificates under the hands of the most sufficient and best inhabitants of the several places and parishes where they dwell, concerning their good behaviour and carriage, and the conveniency of the places fit for such alehouses to be best, and to take speedy course for the punishing and suppressing of all other alehouse-keepers according to the statutes in that case made and provided." The Judges of assize would occasionally themselves suppress an alehouse. Thus, at Exeter Assizes in August 1665, it is recorded that "whereas it appears unto the Court that R. P., who was convicted of manslaughter at the assizes for killing of one G. M., was drinking at the house of one J. M., in the parish of St. Thomas the Apostle in this county, an alehouse-keeper; and that the challenge was made for them to wrestle whilst they sat drinking in the said house, which occasioned the said death. This Court doth, therefore, order that the house of the said J. M. shall be from hence suppressed from being an alehouse any longer" (MS. Order Book, Western Circuit, Exeter, August 1665). In the same way earlier in the century, in the interests of temperance and keeping the peace, "at the Exeter Assizes (1627) Chief Baron Walter and Baron Denliam made an order for the suppression of all wakes. Judge Richardson made a like order for the county of Somerset (1631)" (Ninetecn Centuries of Drink in England, by R. V. French, p. 200). 


\section{LIQUOR LICENSING IN ENGLAND}

all interest in the civil administration of the counties included in their circuits, and after 1688 , at any rate, we find them confining themselves strictly to their judicial functions. Except when Jacobite plots were feared, or serious disorders were threatened, the Justices of the Peace, whether in municipal corporations or on county benches, were, at the end of the seventeenth century, abandoned entirely to their own devices. 


\section{CHAPTER II}

\section{A PERIOD OF LAXNESS}

From the end of the seventeenth century, at any rate, a period of extreme laxness set in. Licences to keep alehouses were granted by any two Justices of the county, whether or not they belonged to the neighbourhood, or had any knowledge of applicant, or his house. We gather that practically any one could obtain a licence, which, once granted, was never withdrawn. The suppression of alehouses by the Justices went entirely into desuetude. There was, on the contrary, a constant tendency towards their multiplication. "The superfluous number of such petty inns and alehouses," complains a contemporary writer, "seems to proceed from these two causes: the first is from the application which is frequently made on the behalf of some broken, half-starved merchant or idle fellow, who rather than beg, or steal, and be hanged, or at best become charge- 


\section{LIQUOR LICENSING IN ENGLAND}

able to the parish, hopes to get a subsistence by the little cheatings and degenerate shifts of aleselling. The other course is much of the same figure, it being commonly no other than the sordid interest of some mean-spirited Justices, who, to maintain a superfluous or indigent member of his family or acquaintance, is tempted easily to license alehouses for the sake of fees." 1

Whether or not we need accept as a true generalisation this cynical description of the Justices' motives, of the actual increase in the number of licensed houses there is no shadow of doubt. With the possible exception of the city of London, ${ }^{2}$ our search through contemporary

1 Campania Felix, by Timothy Nourse (1700), eh. xii. "Of Inns and Alehonses," p. 170.

${ }^{2}$ In the MS. Joumals of the Common Council of the City of London (vol. lii. p. 373), under date of 1700 , there is an order by the Lord Mayor to the aldermen of the several wards, annually repeated for the next few years, "for the better ehoice of all such victuallers, tiplers (sie), alehouse-keepers, and others selling beer and ale, as are to be licensed within this City and liberties thereof, and suppressing those not thought fit to be licensed. These are therefore to will and require you forthwith upon sight hereof to repair into your said ward, and there, as well by the advice of your deputy and common conneil, as upon view of the parties themselves, consider who are fit to be licensed, having respect to their ages, lives, conversations, and places of abode; and that you eertify me under your hand in fair writing the names and surnames of all such persons as yon shall think fit to be licensed within your ward, and in what they dwell, and in what eompany every one of them is free (for you are to present none but what are free of the city)." Corresponding orders were issued to the warl beadles." 
newspapers and official records during the first quarter of the eighteenth century, has revealed no evidence of any care or thought by the Justices, either in restricting the grant of new licences or in regulating the conduct of existing alehouse-keepers. Nor was there any attempt made to limit the traffic to licensed houses. It was a special feature of the period that the sale of beer was not confined to the inns, or victualling houses, and the alehouses, or " mug-houses," as some of them were termed in London. The coffee-houses, which filled so large a part in the public life under William III. and Anne, sold alcoholic drinks as well as coffee. At Shrewsbury, De Foe noted in 1714, there are " the most coffee-houses round the Town House that ever I saw in any town, but when you come into them they are but alehouses, only they think that the name of coffee-house gives a better air." 1

It is therefore scarcely to be wondered at that the consumption of ale and beer rapidly increased. In 1722 the production of malt for brewing beer attained the extraordinary figure of 33,000,000 bushels, indicating a consumption in the year of a whole barrel of beer (36 gallons) for every man, woman, and child of the population, a total production not again reached

1 De Foe's Tour through the whole Island of Great Britain (1724-7). 


\section{LIQUOR LICENSING IN ENGLAND}

until more than a hundred years later, and an average consumption per head which has never subsequently been equalled. ${ }^{1}$

Meanwhile other forms of intoxicating drinks were coming extensively into consumption, and these were to a great extent exempt from the Justices' control. Already in 1553 we are told that "great numbers of taverns" - that is, wineshops-" had recently been set up in back lanes, corners, and suspicious places within the City of London, and in divers other towns and villages within the realm," which became "the common resort of misruled people." 2 Therefore, in the year next following the first licensing of alehouses, all taverns outside the limits of boroughs or market towns were suppressed; those in such towns were limited to two in each place, or to three, four, six, or eight in twenty specified large

1 Report of the Commissioners of Inland Revenue (1870), vol. i. Appendix, 11'. 15, 17 ; 'Twenty-Eighth Report of the Commissioners of Inland Revenue (1885), 1). 20. For the history of the manufacture, retailing, and taxation of ale and beer, see the convenient Beer Manual, by Joseph Scarisbrick (Wolverhampton, 1892).

27 Edward VI. c. 5" (1553). "Tavern-Laberna-was the distinctive name for the wine-liouse of the Midule Ages, as opposed to the alehouse" (History of Taxation and T'uxes, by S. Dowell, 1888, vol. iv. 1. 136). A tavern, it was said, "is a degree, or (if you will) a pair of stairs, above an alchouse, where men are drunk with more credit and apology" (Microcosmography, by John Earlc). Wineslıops were dealt with apart from alehouses until 7792 , but the word tavern seens to have been loosely used already in the eightoenth century for all drinking-places. 
towns; and forty in the city of London. Up to this maximum all taverns were to be licensed, during pleasure, by the municipal corporations or county Justices. ${ }^{1}$ But this extension of the Justices' jurisdiction was, to a great extent, rendered nugatory by the exercise of the King's prerogative, recognised by the statute of 1623 , to give a licence to any tavern-keeper to sell wine. ${ }^{2}$ These royal licences, which were made a

17 Edward VI. c. 5 (1553), Gravesend, Sittingbourne, Tuxford, and Bagshot were speeially included as towns which might have taverns. (As to the Gravesend privilege, sce R. P. Cruden's History of Gravesend, 1843, p. 171.) The Mayor and Corporation of St. Albans enjoyed the exclusive privilege, by charter of Edward VI. in 1560, of appointing three wine taverns in that borough for the maintenance of the local school. Their privilege was preserved by 12 Car. II. c. 25 (1660), 9 Anne, c. 23 (1710), and 43 and 44 Vict. c. 20, sec. 48 (1880), and still exists (Plain Papers regarding the Excise Department, by John Owens (Linlithgow), pp. 496-498; History of Hertfordshire, by Robert Clutterbuck (1815), vol. i. p. 49 ; History of Taxation and Taxes, by S. Dowell (1888), rol. iv. p. 138; The Licensing Law's, by R. M. Montgomery (2nd edition, 1900), p. 2).

${ }^{2}$ For the statutes regulating these royal wine licences, see 12 Car. II. c. 25 (1660), 15 Car. II. c. 14 (1663), and 22 and 23 Car. II. c. $26(1670)$, and 30 George II. e. 10 and 15 (1757). Freemen of the Vintners Company of the city of London were, by their charter of 9 James I. (1612), allowed the privilcge of selling wine without any licence within three miles of the eity of London, in cities and port towns, and in the "thoroughtare towns" on certain great roads. This privilege still continues, but it is now restricted to freemen by patrimony or apprenticeship, who may have each only one house, and must give formal notice to the Exeise (see 30 George II. c. 19, secs. $10-11$; 9 George IV. c. 61 , sec. 36 ; 25 and 26 Vict. c. 22 , sec. 16 ; and The Licensing Acts, by J. Paterson, 13 th edition, 1900, p. 2). In 1737 (10 George II. c. 17) retailers of British wines, mead, etc.technically known as "sweets,"-and in 1792 (32 George III. c. 59) retailers of wine, to be drunk on the premises, were required to be 


\section{LIQUOR LICENSING IN ENGLAND}

regular source of revenue for the Crown, were not abolished until 1757. After the Restoration, as De Foe remarks, taverns multiplied fast, ${ }^{1}$ and the consumption of wine grew apace.

The drunkenness caused by the wine-shops was completely thrown into the shade by the results of the free sale of gin. ${ }^{2}$ During the greater part of the seventeenth century the new art of the distillation of spirits had been a monopoly in the hands of the Distillers' Company and other royal patentees, and the trade had remained small. But after the Revolution, as part of the commercial warfare levied against the French, the importation of foreign brandy was prohibited or heavily taxed, and a general permission was granted in 1690 to all persons to distil and retail spirits made from English-grown corn. The habit of drinking ardent spirits now assumed alarming proportions. The Legislature, far from desiring to suppress this new drink traffic, at first gave it distinct

licensed victuallers, and were thus brought under the control of the magistrates (IFistory of Taxotion and Taxes, by S. Dowell, vol. iv. p. 140).

1 Memoirs of the Life and Times of Daniel De Foe, by Walter Wilson (1830), vol. ii. p. 203.

2 For the history of the manufacture, sale, and taxation of spirits,

see the convenient Spirit Manual, Ilistorical and Technical, by Joseph Searisbrick (Wolverhampton, 1891); Seventh Report of the Commission of Excise Encuiry, 1836; History of Taxation and Taxes, by S. Dowell (1888), vol. iv, 
encouragement. It became an object of the Government to develop the manufacture of English brandy and strong waters, seeing that, in this way, "great quantities of the worst sort of malted corn, not useful to the brewers, hath been yearly consumed by those who set up works for that purpose." Between 1690 and 1701 a series of statutes provided, for the encouragement of these patriotic distillers, that, if they used malted corn, they should pay only a low preferential duty on their product, whilst "French and other foreign brandies" should be as far as possible excluded. No provision had been made by Parliament for requiring retailers of spirits to obtain a licence, and "punch houses" and "dram shops," as the new places were called, multiplied rapidly in London and Westminster. It is true that in 1701 the retailers of British spirits were required to obtain an alehouse licence from two Justices, but as this was found, in the words of a House of Commons Committee, to be " a great hindrance to the consumption of English brandies," it was, in the very next year, so far repealed as to leave the distillers themselves free to open as many retail spirit shops as they chose, and also to permit a like free sale in the case of "all other shopkeepers whose principal dealings

1 House of Commons Journals, 17th and 27th February 1702. 
shall be more in other goods and merchandises than in brandy or strong waters." 1 The result of this free sale of a powerfully intoxicating liquor, rendered specially cheap by the extremely low duty on its manufacture, was a perfect pandemonium of drunkenness, in which the greater part of the population of the metropolis seems to have participated. Not only were there in London and Westminster six or seven thousand regular dram-shops, but cheap gin was given by masters to their workpeople instead of wages, sold by the barbers and tobacconists, hawked about the streets on barrows by men and women, openly exposed for sale on every market stall, forced on the maidservants and other purchasers at the chandler's shop, distributed by the watermen on the Thames, vended by pedlars in the suburban lanes, and freely offered in every house of ill-fame, until, as one contemporary writer puts in, "one-half of the town seems set up to furnish poison to the other half." "Every one who now passes through

112 and 13 William III. c. 11 (1701), and 1 Anwe, stat. 2, c. 14 (1702). An attempt by the Distillers' Comprany to obtain power to inspect all spirits, and insist on good quality, though at first favoured by the House of Commons, was not made law (House of Commons Journals, 17 th and 27 th February, 6th, 18th, and 27 th March 1702).

2 "Theoplilus," in Gentleman's Maga ine, February 1733, vol. iii. p. 88. 
the streets of this great Metropolis," says a contemporary pamphleteer, " and looks into the distillers' shops . . must see, even in shops of a creditable and wholesale appearance, a crowd of poor ragged people, cursing and quarrelling with one another over repeated glasses of these destructive liquors. . . . In one place not far from East Smithfield ... a trader has a large empty room backwards where, as his wretched guests get intoxicated, they are laid together in heaps, promiscuously, men, women, and children, till they recover their senses, when they proceed to drink on, or, having spent all they had, go out to find wherewithal to return to the same dreadful pursuit, and how they acquire more money the sessions paper too often acquaints us."

"Such a shameful degree of profligacy prevailed," writes Smollett, who saw the London of that date with his own eyes, "that the retailers of this poisonous compound set up painted boards in public, inviting people to be drunk for the small expense of one penny, assuring them they might be dead drunk for twopence, and have straw for nothing. They

1 Distilled Liquors the Bane of the Nation, being some considirations humbly offered to the Legislature, with the late Presentment of the Grand Jurics of London, Hiddlesex, and the Tower Hamlets, together with the Report made by His Mujesty's Justice's at Hieks Hall (London, 1736); preserved in the Place Add. MSS. 27825, p. 178. 


\section{LIQUOR LICENSING IN ENGLAND}

aceordingly provided cellars and places strewed with straw, to which they conveyed those wretehes who were overwhelmed with intoxication. In these dismal eaverns they lay until they recovered some use of their faculties, and then they had recourse to the same mischievous potion." 1

Presently we find the general disgust at the carnival of bestial drunkenness which had been allowed to grow up in the metropolis gaining official expression. The Middlesex Justices, concerned for the public order, begin to petition Parliament for immediate action. "The drinking of Geneva and other distilled spirituous liquors," they emphatically state in 1.736 , "hath for some years past greatly increased, especially among the people of inferior rank. ... This pernicious liquor is now sold, not only by distiller's and Geneva shops, but by many other persons of inferior trades, by which means journeymen, apprentices, and servants are drawn in to taste, and by degrees... to ... immoderately drink thereof.'

But, already in 1729, Parliament had tried to cope with the evil by a sudden reversal of policy.

1 History of England, by Smollett, vol. ii. eh. xviii. 1. 430 (1848 edition).

${ }^{2}$ Middlesex Quarter Sessions, Epiphany, 1736; see House of Commons Jouruals, 20th February 1736. 


\section{A PERIOD OF LAXNESS}

In place of "free sale" it had sought to introduce, with regard to the most pernicious forms of alcoholic drinks, a system of licensing and heavy taxation of the retail trade. By the first "Gin Act"-not to be confused with the more celebrated one of 1736-a new and additional excise duty of five shillings per gallon was put on gin and other "compounded" spirits, and every retailer of them was required to pay twenty pounds a year for a licence, whilst the hawking about the streets of any kind of spirits was expressly prohibited.' 'This Act merely led to the invention of new forms of spirit, one of them called in derision "Parliament Brandy," which did not fall within its scope; and it was repealed in 1733, on the plea that, whilst doing no good, it checked the sale of barley to the distillers. The orgy became, however, so terrible that, in 1736, Sir John Jekyll, then Master of the Rolls, induced Parliament to adopt a practically prohibitory policy, extending the policy of the Act of 1729 to all spirits whatsoever, imposing a new tax on the retailers of the enormous sum of twenty shillings for every gallon sold, and restricting this retail sale to publicans who paid fifty pounds a year for the privilege. This drastic measure led only to riots and a complete

12 George II. c. 17 (1729); repealed by 6 George II. c. 17 (1733). 
collapse of the Justices' authority. simply could not be put in force. man . . . foresaw," subsequently

The law "Every remarked a shrewd member of the House of Lords, "that it was such a law as could not be executed, but as the poor had run gin-mad, the rich had run anti-gin-mad, and in this fit of madness no one would give ear to reason." 1

In the course of seven years only two licences at the exorbitant fee of fifty pounds were ever taken out. "Since the populace saw they could not evade the law," Lord Cartaret plainly told the House of Lords "they openly and avowedly transgressed it; and the transgressors were so numerous that they even set the Government itself at defiance. No private man, no under officer durst inform, no magistrate durst punish, without being in danger of being De Witt-ed by the mob as he passed along the streets." 2

1 The Earl of Islay, in the debate in the House of Lords (Parlia. mentary History, 21st Febrnary 1743).

2 Purliamentary Ilistory, vol. ix. P1. 1132-1138; vol. xii. pp. 11911439. For this whole episode, sce Mr. Lecky's History of England in the Eightecnth Century (1883), vol. i. 1'l. 476-482, and the anthorities there quoted; also Smollett's History of Englane (1756-7); Tindall's continuation of Rapin's History of England (1759), vol, viii. pp. 358-388; Lorl Mahon's IListory of England (1839), vol. iii. ch. xxv. pp. 213.214; Macfarlane and Thomson's History of England (1856), vol. iii. P. 258 ; An Argument for the Leyislative Prohibition of the Liquor Traffic, hy F. R. Lces (1856), P. 82 ; History of Drink, by J. Samuclson (1880), pp. 161-162; Nineteen Centurics of Drink 


\section{A PERIOD OF LAXNESS}

It appears that the distillers at Cambridge, rather than pay the exorbitant new taxes under the 1736 Act, "with great loss, disadvantage and expense, converted their effects into the wine trade," and " hired, furnished, and opened cellars and taverns" (see their petitions in House of Commons Journals, 23rd March, 19th April, and 2nd May 1737). This brought down upon them the university authorities, who claimed that by ancient custom the sole right of licensing any kind of public-houses lay in them. To maintain this monopoly, the university obtained a clause in a new Act (see House of Commons Journals, 16th March 1737).

In spite of the fact that no spirits could legally be sold by retail at all-for no one had taken out the necessary licence ${ }^{1}$ - the amount manufactured, on which the excise duty was paid, rose from 4,947,000 gallons in 1734 to no less than $7,160,000$ gallons in 1742 .

The 1736 Act had, it is said, never secured the approval of Walpole, the then all-powerful minister, but he had not cared to oppose the

in England, by R. V. Freuch (1884), 11. 255-292; Gentleman's Magazine, vol. vi. pp. 550, 682 ; rol. vii. Pp. 513, 701, etc.

1 The fact that, in seven years, only two (or three) licences had been taken out, was stated in the House of Lords by Lord Bathurst, on the authority of Burton, a Commissioner of Excise (Parliamentary History, vol. xii. pp. 1201, 1294). 
momentary tide of opinion in Parliament. Within a very few years it became evident that it had totally failed to suppress excessive gin-drinking. Though' the Government got no revenue either from licences or the duty on retail sales, the consumption was enormously increasing. "You ean hardly pass along any street of this great eity," said the Bishop of Salisbury in 1743 , "at any hour of the day, but you may see some poor creatures mad drunk with this liquor, and committing outrages in the street, or lying dead asleep upon bulks, or at the doors of empty houses. It is true we have not now those publie and open scenes of wickedness and debauchery that appeared in every gin-shop before the making of the law ... but the trade is carried on, though more privately, yet with as great excess as ever, and the reason we do not see more objects in streets is because most of them sleep out the dose in the private corner where they took it in." 1

"Every one knows," said Lord Bathurst, "that the 1736 Act did not diminish the consumption, nor prevent the excessive use of spirituous liquors. They were not, it is true, retailed publicly and avowedly, but they were clandestinely retailed in every coffee-house and

1 Purliumentary History, 21st February 1743. 


\section{A PERIOD OF LAXNESS}

alehouse, and in many shops and private houses, so that the use and even the abuse of spirituous liquors continued as frequent, though not so apparent, as before the Act was made; and the consumption rather increased than diminished, as appears from the amount of the duty for these last two years." I

It is clear that the Act of 1736, as it stood, was of no use. To strengthen both the law and the administration in such a way as to make it really effective would have caused a diminution in the revenue. By 1743 , the Government needed actually more revenue, and was in no mood to dispense with any. It therefore brought forward a Bill which it had got drafted by Kent, one of the great distillers of the time. ${ }^{2}$ This measure repealed the 1736 Act, and adopted the policy ever since maintained in this country, namely, the combination of revenue duties on the manufacture of spirits, with the licensing of retailers at a moderate annual fee under magisterial supervision. This momentous reversal of policy "was hurried through the House of Commons with the utmost precipitation, and passed almost without the formality of a debate." ${ }^{3}$

1 Parliamentary History, 21st February 1743.

2 Ibid. vol. xii. p. 1299.

3 Lord Chesterfield's speech, Parliamentary History, 21st February 
But in the House of Lords the enemies of Ministers rallied their forces, and they were powerfully aided by the whole bench of bishops. The debate which ensued happens to have been more fully recorded than, perhaps, any other parliamentary discussion of the century.? The Government urged that the Bill, though removing the virtual prohibition professedly imposed by the Act of 1736, would really diminish the consumption of spirituous liquors, by enabling it to be brought under control. "We find by experience," said Lord Bathurst, "that we cannot absolutely prevent the retailing of such liquors. What then are we to do? Does not common sense point out to us the most proper method, which is to allow their being publicly retailed, but to lay such a duty upon the still head and upon licences as, without amounting to a prohibition, will make them come so dear to the consumer, that the poor will not be able to launch out into an excessive use of them."

1743 ; Memoirs of sir Robert Walpole, by W. Coxe (1798); History of Enyland, by Lord Mahon (1839), vol. iii. ch. xxv. p. 213.

${ }^{1}$ Besides the general histories already cited, the student of this great debate will consult Arehbishop Secker's Diary under 24th February 1743, in his Works (1811); Ebenezer Timberland's History and Proccedings of the House of Lords (1744), vol. viii.; Cobbett's Parliamontary History, which devotes no less than 248 pages to the proceedings (rol. xii. pp. 1191-1439); the London Magasine, October 1743 ; and the Gentleman's Magazine, November 1743. 


\section{A PERIOD OF LAXNESS}

The bishops, on the other hand, strenuously opposed the setting up of a traffic destructive alike of health and morality. They seem to have suggested as a remedy an increased stringency of the prohibitory law, and the exercise of greater care by the Justices in granting alehouse licences. "If," said the Bishop of Salisbury, "Justices of Peace did their duty they would be much more cautious than they are in granting or continuing licences; but they never did, they never will do, their duty in this respect. Do not we know that they never do refuse a licence to any one that is willing and able to pay for it? Are there not now many notorious vile houses licensed as coffee-houses or alehouses? Do not we know that when such houses become a nuisance to the whole neighbourhood, it is with the utmost difficulty that the honest neighbours can prevail with the Justices to take away the licence?"

Lord Hervey, in opposing the Bill, endorsed this condemnation of the Justices, and urged that their laxness was directly encouraged by the financial interest of the Government in multiplying licences. "Originally," he said, "no licence was granted unless upon inquiry it was found that such a house was in that place really wanted for the convenience of the neighbour- 
hood. . . . But since the high duties and excises have been laid upon wines, and upon beer and ale, has such an inquiry ever been made? Has not a licence been granted to every one that asked it? Has not the execution of our laws against drunkenness and tippling been most egregiously neglected? This, my Lords, will be the consequence of the duty now proposed to be laid on gin. The duty proposed is not near so high as to amount to a prohibition. . . . It is not designed as such; it is designed as a fund for bringing money into the King's exchequer, and therefore ... the use of this commodity, and even the excessive use of it, will be encouraged, or at least connived at by the King's Ministers, and by all those under their direction. The Justices of Peace may, perhaps, for the first year or two refuse granting a licence to a house known to be designed to be made a ginshop under the pretence of being a coffee-house or alehouse; but they will soon have private directions, and a licence will be granted to every one that desires it. . . . I foresee that if you again open gin-shops under the denomination of coffee-houses or alchouses, we shall presently have a new deluge of all those calamities which were so severely felt, and so much complained of in the year 1736." 


\section{A PERIOD OF LAXNESS}

It is needless to add that, notwithstanding the zeal and fervour of the bishops, and the eloquence of the noble opponents of the new administration, the new Prime Minister got his way. The Bill of 1743 passed into law. ${ }^{1}$ The retail licence duty was reduced from $£ 50$ to $£ 1$, and the prohibitive duty of $20 \mathrm{~s}$. per gallon on retail sales was abolished, whilst the very moderate duty then levied on the manufacture was only slightly increased. ${ }^{2}$

These incessant and revolutionary interferences by Parliament with the regulation of the liquor traffic between 1690 and 1743 absolve, we think, the Justices of the Peace from any considerable responsibility for the outburst of bestial drunkenness and brutal disorder that characterised the first decades of the eighteenth century. But it is clear that neither in London nor in the country did they show any zeal or efficiency in exercising the powers which they possessed. Alehouses, which were exclusively under their jurisdiction, were greatly multiplied in number. All this time, moreover, the laws

116 George II. c. 8 (1743).

2 In 1747 there was, for reasons unknown to us, a temporary departure from this policy, in that distillers were allowed to retail without magisterial licence. This led to abuses, stigmatised by $\mathrm{H}$. Fielding in his Inquiry into the Causcs of the Late Inerease of Robbers (1748), and to the total prohibition of distillers to retail, even with a licence, in 1751 . 
against "continuing drinking" or "tippling" were in full force, and the Justices were expressly required to see that the victuallers whom they licensed prevented any such "continuing drinking, and maintained good order in their houses." Yet we do not hear of any withdrawal of licences for misconduct, or the suppression of unnecessary drinking places. From 1701 onward, as we have seen, the law, though subject to large exceptions, required the ordinary "dram-shops" and "punchhouses" to be licensed, and the indiscriminate retailing of spirits was plainly illegal; but there is no indication in Hogarth's "Gin Lane" of any interference by the Justices or the constables." To induce the vendors of spirituous liquors to take out a licence was, no doubt, in the contemporary anarchy, a difficult and unpleasant task.

1 Yet cven the Middlesex Justices could be particular enough if they chose. "One of the curious sights of the year 171\%," writes Dr. Doran, "was the assembling by summons of a thonsand Middle. sex tavern-keeper's in front of Hicks' Hall, where announcement was made to them that in future no licence would be granted save to those who had taken the oath of allegiance before the Justices of the various parishes" (London in Jacobite Times, by Dr. Doran, 187\%, vol. i. p. 285). So in 1745 , a critical year, we read that the magistrates for the division of St. George's, Hanover Square, in petty sessions, resolved "that for the future no persons that are Roman Catholies, or others who shall refuse to take the oatls of allegiance and supremacy, be admitter to have licenees in this parish. That all persons that shall hereafter apply for new licences do first take the oaths of allegiance and supremacy, and repeat the declaration against transubstantiation" (MS. Minutes, Petty Sessions, St. George's, l[anover Square (Middlesex), 5th October 1745). 


\section{A PERIOD OF LAXNESS}

"When a Justice of the Peace," we are told, "meets with inferior officers of courage and intrepidity, and sets about a reformation of the unlicensed houses, he finds himself surrounded with numbers of pettifogging attorneys and solicitors who watch his steps, and if there happens to be the least flaw in the method of drawing up and managing the several proceedings, he finds himself obliged to attend a certiorari in the King's Bench, where, failing in some circumstance, the whole proceedings are quashed, and the magistrate, who has been at great expense, has the mortification to see the impudent fellow triumph over him and increase his iniquitous trade." 1 The committee of Middlesex magistrates which reported to Quarter Sessions in 1736, may well have been "firmly persuaded that there has been great negligence and remissness in several of the officers in this occasion," seeing that they discovered that nearly half the constables whom they employed were themselves retailers of spirituous liquors. "While all other tradesmen endeavour to get excused from serving the office of constable, the dealers in Geneva court the office, whence they infer that the constables find their account in encour-

1 Distilled Liquors the Bane of the Nation (1736), p. viii. (p. 180 of Add. MSS. 27825). 


\section{LIQUOR LICENSING IN ENGLAND}

aging the commission of vices and crimes." The net result was that in 1736 this committee reported the existence, not only of almost innumerable cases in which spirits were clandestinely sold in cellars, garrets, and backyards, but, in the metropolitan parishes alone (excluding the city of London and Southwark), of no fewer than 2105 open and regular retailers who kept dram-shops without being licensed, as compared with 4939 holders of licences; and that these had formed a common fund to defend themselves against the prosecutions which the Justices were afraid to institute. The licensing powers of the Justices, as well as the laws of Parliament, were, in fact, simply set at defiance.

In this dilemma Parliament seems to have found no alternative to the policy of throwing all responsibility upon the Justices of the Peace. The ten years which succeeded the main Act of 1743 witnessed a series of minor reforms, all directed towards making more effective the Justices' authority. Licences were to be granted only at the annual "Brewster Sessions," specially summoned for the purpose, and at no other time $;^{1}$ the procedure as to the transfer of licensed houses was systematically regulated $;^{2}$

126 Greorge II. c. 31.

226 George II. c. 31 and 29 George II. c. 12. 


\section{A PERIOD OF LAXNESS}

no .Justice who was himself a brewer or distiller could take part in granting a licence; ${ }^{1}$ the fee of the Justice's clerk was expressly restricted to half a crown, ${ }^{2}$ whilst the Government stamp was raised to a guinea. ${ }^{3}$ No licence was to be granted to any person but the keeper of a house of public refreshment for that house only; ${ }^{4}$ and the licensee was not allowed to carry on the trade of grocer or chandler, or that of a distiller, or to keep a "brandy shop." 5 As some guarantee that the premises were of sufficient size, they had (if spirits were to be sold as well as beer) to be rated to the poor rate, and in London to be of at least $£ 12$ rental or $£ 10$ ratable value. ${ }^{6}$ The licensee had not only to enter into his own recognisances for good behaviour, but had also to furnish two sureties for the same. ${ }^{7}$ Moreover, no new licence was to be granted outside London and the corporate towns, except on the certificate of the incumbent and churchwardens of the parish, or of three or four substantial householders therein, that the applicant was "of good fame and sober life and conversation." 8

126 George II. c. 31 c. 13 , sec. 11.

224 George II. c. $40 . \quad 329$ George II. c. 12.

417 George II. c. 17, c. $19 . \quad{ }^{5} 17$ George 1I. c. 17 , c. 19.

624 George 1I. c. 40 ; 26 George II. c. 13.

726 George II. c. 31, see. 1.

${ }^{8} 26$ George II. c. 31 , sec. 16 . 
Finally, in order to strengthen the hands of the Justices, the procedure relating to their proceeding against defaulting publicans was simplified and defined; ${ }^{1}$ they were protected against. writs of certiorari and actions for damages, and they were given summary power's of search and discovery. $^{2}$ From 1753 onward, at any rate, the Justices had in their uncontrolled discretion to grant or refuse a licence, and in the crushing penalties against unlicensed sellers, an almost unlimited power of confining the drink traffic within legitimate bounds. ${ }^{3}$

During the decades immediately following the legislation of $1743-53$, the Justices seem to

126 George II. c. 31 , sec. 7,$8 ; 28$ George II. c. 19.

224 George II. c. 40, and 26 George 11. c. 31 , sec. 9.

3 Trustworthy statistics of the consumption of spirits cannot be given, owing to the varying prevalence of illicit distilling, and the uncertainty as to the amount suuggled from other countries. For the first half of the eighteenth century the statistics of the amount of British spirits charged with duty seem to have, at any rate, some significance. The records begin in 1684, when the total was only 527,492 gallons, and it did not reach a million until 1696 . It then rose rapidly to $2,200,721$ in $1710,3,379,695$ in $1722,4,612,275$ in $172 \pi$, and $6,074,562$ in 1734 , the known prodnction being thus at the latter date about one gallon per head of the estimated population of England. The first Gin Act of 1729-33 effected no reduction at all. The second, of $1736-43$, cansed the amount to fall ofl for the first three years only, the increase for the last four years of its opera. tion being at a greater rate than before. This was again checked by the Acts of 1751 and 1753 , when the total amount fell from $7,049,822$ gallons in 1751 to only $4,483,341$ in 1752 , and to $1,849,370$ in 1758 (see the tables in First Reprort of the Commissioner's of lnland Revenue, 1857, Aplendix, No. 19). 


\section{A PERIOD OF LAXNESS}

have set themselves to carry out the spirit of Walpole's Act, by aiming at licensing the sale of alcoholic liquors rather than restricting, or even controlling it. Gradually, with many prosecutions, the indiscriminate sale of liquor in London and Westminster was put down, but only at the cost of steadily increasing the number of licensed houses, and allowing them to remain practically unregulated." In 1750 we learn that " 7000 out of 12,000 quarters of wheat sold in the London markets per week were converted into spirituous liquors . . . and there were 500 out of 2000 houses in the parish of St. Giles-inthe-Field open for" their sale." "The suburbs of the Metropolis," writes Smollett of 1752, " abounded with an incredible number of publichouses, which continually resounded with the noise of riot and intemperance; they were the haunts of idleness, fraud, and rapine, and the seminaries of drunkenness, debauchery, extravagance, and every vice incident to human nature." 3 In contrast with the drastic "articles"

1 "In 1750 the following is given as an authentic account of the proportion of (drink shops) . . . in the City of London one to every fifteen houses; in Westminster one to every eight dwellings; in Holborn district one to every five; and in St. Giles above one to every four houses" (History of the Temperance Movement, by Samuel Couling (1862), p. 19).

2 Gentleman's Magazine, January 1760, p. 21.

3 History of England, by 'T. Smollett, ch. xxii. vol. iii. p. S1 of 1818 edition. 
enforeed by the Justices under James the First, those who were commissioned by George the Third made, for the first twenty years of his reign, absolutely no attempt to enforce the laws against tippling, or to stop drinking during divine service on Sunday, or to prescribe any hours of closing, or even to require the observance of the most elementary decency. The overgrown parishes of the metropolitan area became specially notorious for their gin-shops and night-houses." "In many parts" (of the Metropolis), writes a reviewer of 1759, "particularly in Chelsea, every house, comparatively speaking, is a public-honse." 2 In Westminster, in spite of an unrepealed order of 1585, by which the High Steward and Burgesses had ordained that there should be "one hundred common alehouses and no more" within the city and liberties, there were in 1770 no fewer

1 "These 'night-houses' were kept open the whole night, professedly for the purpose of receiving all manner of persons who think proper to resort to them ; where every one is prermitted to sit tippling and gambling the whole night-aprentices, journeymen, family servants, known thieves, the most abandoned prostitutes, all assemble and mix together" (Address by W. Mainwaring to the Middlesex Grand Jury, 12th September 1785; see Chelmsford Chronicle, 21st $\Lambda_{\text {pril } 1780) .}$

2 Monthly Review, December 1759, vol. xxi. p. 575, in a notice of a pamphlet entitled The Number of Alehouss shown to be extremely Pernicious to the Publick, hy the Vicar of S. in Kent, 1558. This little work, which is signed R. C., is by the viear of a small rural parish. 


\section{A PERIOD OF LAXNESS}

than two thousand. ${ }^{1}$ Loud and frequent are the complaints of the obvious partiality and corrupt laxity of the Middlesex magistrates, " men of profligate lives, needy, mean, ignorant and rapacious," Smollet calls them, in all that concerned licensing. ${ }^{2}$

The magistrates of the other counties and municipal boroughs, though free from the gross and unashamed corruption of the "trading Justices" of Middlesex, seem to have been, between 1729 and 1786, hardly less negligent in the performance of the duties which Parliament had cast upon them. In most parts of the country it became, apparently, easy to get an alehouse licence, and we hear on all sides that

1 A Brief Account of the Poucrs given to and Excreised by the Burgess Court of Westminster, by An Inluabitant of Westminster (n.d. 1770 ?), p. 12 .

2 The disreputable pullic-houses in St. Luke's parish, in spite of the laws against tippling and drinking during divine service, had "benches set at the doors" on Sundays to accommodate their crowds of customers. "And do not the churchwardens and Justices," asks an indignant eritic in 1782 , "see many wallowing in the strcets who have been harboured all night at the houses alluded to? Why not severely fine the occupiers of these houses for such conduct; and if that does not remore the evil, you are justified in preventing their ever leing again licensed. The time of renewing licences is now near at hand. You are hereby publicly called on to remove the evil. You as managers of the affairs of this parish can, with propriety, and without any partiality, remove that which individuals cannot, and by complying with which you will gain the approhation of every peaceable inhabitant" (Gazctteer, 2nd Angust 1782 ; and again to the same effect, 19th February 1782). 
the number of "little alehouses, those nurseries of highwaymen, street robbers, housebreakers," etc.," was enormously increased." The characteristic desire of the eighteenth century governing class to extract revenue out of the evil propensities of the population ${ }^{3}$ had, as Lord Hervey predicted in 1743 , seriously infected the licensing work of the Justices. "We are unhappily fallen," said the Gentleman's Magazine already in 1739, " into a way of raising great part of the public and civil list revenue on malt, beer, wine, etc., the consumption of which, and consequently the revenue, is mightily increased by the vices of the people. This naturally stops the current of justice, and is an over-ruling argument with

1 See, for instance, the correspondent to the London Magazine, Narch 1758 (rol. xxvii. p. 135).

2 "I live in a conntry village," says a writer in 1751, "and we have six common stews or alehouses; they brew near 130 quarters of malt in the year. Our farmers drink but little, our day-labourers drink less; the consumption is chiefly by om weavers and combers" (Gentleman's Magazine, May 1751, p. 206).

3 The use made of lotteries is one example of this desire. Nor was it altogether in jest that a writer, in 173\%, proposed that the National Debt should be paid by a tax on each particular vice. "Drunlienness he taxes at sixpence, and supposing only 20,000 persons daily liable to be taxed, the amonnt wonld be $₫ 500$ per day. This is a moderate computation if one considers that, besides the usual opportunities of taverns and private houses, there are elections, fairs, mayors' feasts, university treats, corporation dinners. Christmas regals, weddings, and christenings; but would exempt county Justices and parsons, not willing they should be insulted by inferior oflicers" (Read's Journal, 22nd January 1732, quoted in Gentleman's Mregazine, January 1732). 


\section{A PERIOD OF LAXNESS}

avaricious ministers and falsely loyal magistrates, not to exert themselves, according to their duty, to nip the first buddings of vicious, disorderly spirits. Hence the innumerable alehouses with which England abounds; hence the non-execution of so many good laws against tippling houses. . . To this may be added a supine neglect of duty too apparent in many magistrates, who seem to have little sense of the concatenation of vicious habits and unruly actions with each other, and over some of whom the large fees for warrants, licences, mittimuses, orders, etc., into their clerk's, or their own pockets, may reasonably be supposed to have some little influence. Within these two years I was at a session held at a trading town in Wilts for licensing alehouses, where there were seven Justices, one of whose clerks told me with an air of gladness that his share came to between three and four pounds." 1

Nor were the brewers and distillers idle in the promotion of the trade. They are "not contented," says a writer in 1773, "with such trade and gain as might fairly and spontaneously arise," and "are known to buy up paltry houses and settle retailers in every little parish, as well as in every town and city, and for fear there

1 Gentleman's Mragazine, March 1739, p. 124. 


\section{LIQUOR LICENSING IN ENGLAND}

should be a place in the kingdom exempt from their advantage, we have scarce a village without some of their cottages and huts, where servants and labourers, inferior tradesmen and handicraftsmen, young people and old, are secreted and allured by various sports, pastimes, and fooleries, till, intoxicated with every mixture that can tempt the palate or drain the pocket, they swallow in like swine the filth of debauchery, and are a disgrace to our laws and a reproach to human nature." 1

Avarice, whether public or private, was, it is hardly nccessary to say, not the only influence at work on the mind of the licensing Justices; there was also the charitable desire to help poor people to get a living. The evil multiplication of "petty alehouses," says a writer in 1766, "arises from a mistaken notion in many reputable people in different parishes, who think that, by signing certificates to the Justices to obtain licences for some needy persons, they thereby kecp them off the poor rate, and prevent their being troublesome to the parish." . . . The situation of these little public-houses is commonly on the side of a common . . . or some such place, and being out of the public road, of course are of no service in accommodating

1 Monthly Review, January 1773, vol. xlviii. p. 20. 


\section{A PERIOD OF LAXNESS}

travellers. The chief support, therefore, of the occupiers of them arises from their harbouring and entertaining poachers, as well as others who pursue indirect practices, and also from enticing labouring men to loiter their time and spend their money with them." 1 Nor were things any better in the corporate boroughs. The little town of Woodstock (Oxfordshire), for instance, which cannot, at the middle of the eighteenth century, have had more than a thousand inhabitants

1 London Chronicle, 26th-28th June 1766.

The laxity of the Justices in granting too many licences is strongly animadverted on in The Number of Alehouses shown to be extremely Pernicious to the Publick, by the Vicar of S. in Kent (signed R.C.), 1758.

We do not know how far the following lively picture of a licensing sessions in 1754 may be aecepted as typical. At "the Brewster" sessions at Bray in Northungria" five Justices are repuesented as being present. "Mrs. Drab" eomes in to apply for a renewal of her licence; she brings a eertifieate signed by some of her neighbours, certifying that "Mrs. Drab of the Rount O keeps a very regular and orderly house; and that we have been often entertained there with much pleasure, wit and hmour; and desire that her lieence may be renewed ; for we camnot live without her and hers."

Sir John Bear-"The found O lies in my neighhourhood. I wish there was never a Round O near me; it debauches my servants. I could give many reasons why she ought not to have a licence." Mr. J. Lock then refers to "irregularities committed at the house in April" and "shametul doings in May and June," and "intamous revels in August." Other objections are made.

The Chairman-"Hem! hem! There are two Justices required to the granting every licence by the statute. Brother Friar, you and I must sign it. The woman must not be undone, nor the excise diminished. The house draws a great deal of ale, and pays a round sum into the office." (They sign the lieence).-Gentleman's Magazine, October 1754. 


\section{LIQUOR LTCENSING IN ENGLAND}

always had over a score of alehouses. ${ }^{1}$ In the wide area of the borough of Leeds, which covered twenty square miles of country, the terrible increase in the "nightly depredations committed in the town and neighbourhood" is, in 1786, attributed largely to "the immense multitude of the lower sort of alehouses within the borough. . . They are too numerous to enable their inhabitants to gain a livelihood by fair and honourable means. In one village not far from Leeds.. . their number is between thirty and forty. . . These little pothonses .. . are the rendezvous of these nocturnal villains, where they plan their depredations, and where not unfrequently they divide their spoil." 2 All the keepers of these alehouses and gin shops, these haunts of criminals and "night-houses," it must be remembered, had entered into elaborate recognisances for good behaviour and came up annually for a renewal of their licences. The

"Minntes of "Portmonth Court" and "Acts" of the Town Council; see Chronicles of Woodstock, by A. Ballard (Oxford, 1896). Occasionally the granting of new licences in corporate towns was checked loy the influence in the corporations of local brewers, who did not want the business of their own licence-holders competed with. Snch a case certainly occurred at Canterbury (Kent); see Charters Destructive to Liberty and Property, by Thomas Roch (1776), pr. 85-93. But the testimony of the Municipal Corporation Com. missioners in 1835 learls us to think that such influences were not (.ommon.

2 Lerds Intelligencer, 25th $\Lambda_{\text {pril }} 1786$. 
remissuess of the Justices in neglecting their powers of control was as complete and universal as their laxness in granting licences. The recognisances and surety bonds and certificates became mere meaningless formalities. ${ }^{1}$ In one county, at any rate-that of Durham-the "practice... had long prevailed of signing blank licences, and leaving them to be filled up at the discretion of the Clerk of the Peace." :

1 Here is a description of the recognisances at the latter prart of the eighteenth century: "On every day of licensing the Clerk of" the Peace or his deputy attends the meeting of the Justices of the Peace, and upon a large roll takes a recognisance of the alehousekeeper, who produces any sureties without enquiry being made into their eircumstances upon oath (which I admit the statute doth not empower the Justices to do), and for this he, the Clerk of the Peace, receives twelve pence, whieh I am sorry to say is the only advantage arises to any one from these recognisances, and then the roll is carried to the Clerk of the Peace office and never heard of after . . . and hereby is this statute of King Edward VI. evaded " (Serious Thoughts in Regard to the Pullich Disorders, by a County Justice of the Peace (n.d.), pp. 14, 15).

2 Paley, when rector of Bishop Wearmouth and a Justice of the Peace, induced the Jnstices to abandon this lax practice (see Memoirs of William Paley, D.D., by George Wilson Meadley (Edinburgh, 1810), p. 192).

It is unfortunately impossible to grive statisties of any significanee as to the increase of licences, and the amount of consumption during this period. No statistics as to the total number of alehonse licenees were obtained until 1810, when the stamp on the licence was replaced by an excise duty (by 48 George III. e. 143 of 1808). There were said to be 40,000 in 1773 , for a population which probably did not then reach eight millions (Jonthly Review, Jan. 1773, vol. xlviii. p. 20); but this was far within the mark.

The number of spirit licences is known, and it is significant that this rose from 22,821 in 1744 to no fewer than 37,172 in 1779 - a highwater mark not again reached, in spite of the enormous growth of 


\section{LIQUOR LICENSING IN ENGLAND}

population until 1811 (see Appendix $32 a$ to First Report of Commissioners of Inland Revenue, 1857). In this period there was so much illicit distilling, private brewing, and smuggrling of foreign spirits that the revenue statistics afford no guide to the total consumption. The statistics of malt and British spirits charged for duty between 1758 and 1784 show a fairly stationary taxed production ; for beer somewhat less than in 1716-27 ; for spirits only a third of the swollen totals of 1734.51 (see the tables in Appendices Nos. 19 and 20 of First Report of Commissioners of Inland Revenue, 1857 ). 


\section{CHAPTER III}

\section{REGULATION AND SUPPRESSION}

WE come now to the most remarkable episode in the whole history of public-house licensing in England, the sudden and almost universal adoption by county and borough benches of a policy of restriction and regulation, lasting, in a systematic and self-conscious form, only for half a dozen years, but surviving in most of the counties as an ideal, and to some extent as a governing principle, right down to the adoption of Free Trade in Beer by the Parliament of 1830. This episode, which has, so far as we know, never been descriled, included the deliberate and systematic adoption, by benches of magistrates in different parts of the country, of such modern devices as Early Closing, Sunday

1 We have found no mention of it in the voluminous literature of the temperance movement, so far as we have examined it; and we are not aware of any ease in which it has been cited in the various Parliamentary inquiries from 1817 to 1900. 
Closing, the Refusal of New Licences, the Withdrawal of Licences from badly conducted houses, the peremptory closing of a proportion of houses in a district over-supplied with licences, and in some remarkable instances, even the establishment of a system of Local Option or Local Veto, both as regards the opening of new public-houses and the closing of those already in existence, all without the slightest idea of compensation." As this reform movement was not only important in itself, but is of special interest in our own day, we propose, principally by means of extracts from contemporary sources, to describe it at some length.

We have elsewhere ${ }^{1}$ described the powerful movement for the reformation of the manners and morals of the lower orders which was inaugurated by Zouch and Vilberforce in 1786-87, cordially endorsed by the pious king, and supported by the whole governing class. This movement came, as we pointed out, from several distinct but converging currents of public opinion-the new-found Evangelical zeal for saving men's souls, the growing dislike of the propertied class of the insecurity of life and property, the alarm both of the financier and the ratepayer at the increasing burden of the poor

$$
\text { ' See Appemlix, 1]1. 137-151. }
$$


rate, and last but not, we think, least, the halfconscious desire of the rising class of industrial capitalists to drive the manual workers out of the alehouse and gin-shop into the factory and workshop. Such being the influences at work, it is not surprising that the most signal and durable manifestation of the movement should have been a strenuous attempt to restrict the temptations to, and the opportunities for, licentious conduct, disorderly gatherings, wasteful expenditure and idle hours, which an unlimited supply of unregulated public-houses afforded to the lower orders. $^{1}$

The first indication of the movement came from the heart of the new manufacturing districts. $^{2}$ The high earnings of certain classes of

1 "That many (alehouses) are opened withont any licence at all; that many are improperly licensed, being nore in number than are necessary; and being in situations very dangerous and remote from the public eye; and that very many of those which are licensed are irregularly conducted, are facts which no one will venture to contradict" (Narrative of Proceedings tending touards a National Reformation, 1787, p. 5).

${ }^{2}$ Individual magistrates up and down the country had for some time been suggesting the propriety of restriction. Thus, in a jamphlet entitled Thoughts on the Great Circumspection necessary in Licensing Public Houses, a country Justice of 1777 earnestly exhorts his brother magistrates not to licence any but absolutely necessary alehouses, to make "the most strict and implartial inquisition" into their conduct, and "to exereise with unremitting vigonr the power entrusted with them," and " to lay the axe to the root of an enormous and growing evil" (see Monthly Reriew, Nov. 1777, vol. lvii. p. 408). 


\section{LIQUOR LICENSING IN ENGLAND}

operatives in the new textile and iron manufactures had led to a pandemonium of hard drinking and brutal amusements. We find the Lancashire Justices in Quarter Sessions in 1782 giving public notice that, "whereas divers innkeeper's within the said county have for some time past made a common practice of suffering great numbers of ill-disposed persons to assemble at their houses and fight cocks, to the great impoverishing of themselves and their families, and to the great encouragement of vice, ... in future no licences will be granted to any ... who shall encourage, connive at, or suffer the fighting of cocks at or in their houses, outhouses, or grounds, and that the magistrates ... are determined to prosecute and punish all such persons." " Presently, fiscal changes gave a great stimulus to the drinking habits of the new manufacturing population. The manufacture of British spirits, which had remained for five-andtwenty year's at a relatively low level, and had even drooped under the heavy war taxes of 1780-85, suddenly bounded up in 1785 , on the reduction of the duty, and rose to double its accustomed amount. ${ }^{2}$ It is not without

1 Laneashire Quarter Sessions, Easter 1782 (see Manchester Nereury, 28th May 1782).

2 See the statistics in $\Lambda$ ppendix No. 19 of First Report of Commissioners of luland Revenue, 1857. 
significance that, in 1786 , the West Riding Justices found themselves driven to consider seriously the condition of the county, and that they incorporated in their general scheme of reforms of "police" strict rules with regard to licensing. A general reduction in the number of publichouses was, they stated, eminently desirable. In the meantime, they gave notice that all publicans offending against the law would have their licences withdrawn and their recognisances estreated.' That this was no empty threat was proved at the next Brewster Sessions at Barnsley, where "the licences of several alehouse-keepers were stopped, who had entertained tipplers, particularly on Sundays, and encouraged cockings, bull-baitings, bear-baitings, etc." " The Royal Proclamation against vice and immorality, issued at the instance of Wilberforce early in 1787, and sent by the Home Secretary to every bench of magistrates, set going a national movement in the same direction. Throughout the next two or three years we find recorded in every provincial newspaper from one end of the kingdom to the other the repeated discussions and elaborate resolutions of the county Justices as to the evils which neglect had produced, and the

1 West Riding Quarter Sessions, Easter 1786 (see Lceds Intelligeneer, 16th May 1786).

${ }^{2}$ Leeds Intelligencer, 19th September 1786. 
way to remedy them. Each county recognised that too many alehouses had been licensed, and that these "swarms of petty pothouses" had, from lack of regulation and supervision, become " haunts of idleness," "nurseries of sottishness," and "seminaries of crime." Practically, every county resolved to insist on a strict observance of the laws against allowing gaming or cock-fighting on licensed premises, tippling during divine service, and the harbouring of vagrants. Everywhere the constables were incited to more diligent supervision, ${ }^{1}$ and the ministers and churchwardens were urged to greater care in signing certificates in support of new licences, and to be prompt to report any misconduct of the alchouse-keepers already licensed. But in many comnties the Justices went much further, and prescribed for themselves in Brewster Sessions rules of action, and for the publicans conditions of licensing, which not only revived the "articles" enforeed by the Justices under James I., but even anticipated nearly all the suggestions of modern temperance reformers.

1 The effect of the 1787 proclanation in stiring up the then Mayor of Leeds to an active enforcement of the law is deseribed in the Life of William Iley, hy John Pearson (1822), pp. 109-131. The Mayor's campaign against the liquer-sellers led to a great outcry, and several vexatious actions were instituted against him and his constables by aggrieved publicans. 


\section{REGULATION AND SUPPRESSION 55}

To begin with the Justices' own action, we see them putting the procedure of granting the licence, and the relation to the publican of the local constable, on a more satisfactory footing. The Surrey Justices resolved "that licences refused at any or either of these meetings shall not be granted at any other time or place without the consent of the majority of the Justices present at the time of such refusal." They went on to prohibit skittle grounds and billiard tables, and to determine that houses shut up on account of disorders suffered therein should not be re-licensed for the ensuing year, and that whenever a mere dram-shop became vacant by death or removal of the occupier, its licence should lapse for ever. ${ }^{1}$

The Justices of the Northern Division of the Lath of Aylesford, Kent, gave public notice that "if any information shall be given to the said Justices on or before the licensing day, of any irregularities committed or encouraged at any alehouse within the said Division, such as permitting the playing at cards, skittles, or any other game prohibited by law to be there used; suffering tippling, especially on Sundays during the time of divine service; keeping late

1 Surrey Quarter Sessions (see P'ublic Advertiser, 17th August 1787). 


\section{LIQUOR LICENSING IN ENGLAND}

and irregular hours, and entertaining night customers," they would not only stop the licence, but would also cause proceedings to be taken to estreat the recognisances. ${ }^{1}$

It was ordered in various counties that no publican should henceforth be "appointed either" high or petty constable," 2 nor accepted as surety for another applicant for a licence;" nor was any "beadle" or "other parochial servant" to be allowed to act in that capacity. ${ }^{4}$ On the

${ }^{1}$ Kentish Gazctte, 10th August 1787. This notice seems to have arisen from the charge to the grand jury of the chairman of Quarter Sessious at Maidstone, in which, replying to the question, "Why are not these houses suplressed?" declared that magistrates conld not aet without formal information being laid before them (Kentish Gazcttc, 20th July 1787) - a confusion of mind between their judicial character and the essentially administrative duties cast npon them in licensing which goes far to explain their failure. "I take upon me to say," he continued, "that the magistrates have not been remiss. 1 cannot recollect an instance where a proper information has been given and it has not been attended to. Magistrates, I will allow, have been merciful, and if that be a fault, His Majesty's proclamation has now set a keener cdge on the sword of justice."

2 Oxfordshire Quarter Sessions, 10th July 1787 (see Bristol Journal, 15th September 1787). Licensed victuallers had been expressly disqualified to be constables in Westminster by the Local Act, 29 George II. c. 25 (1756). The adoption of a similar rule by the Justices elsewhere, "numberless inconveniences having been found to arise from such aplointmeut," is recommended in The Whole Duty of Constables, by an acting nagistrate of the county of Norfolk (Norwich, 1810), p. vii.

3 Justices for the Bampton Division of Oxfordshire (see Jackson's Oxford Journal, 18th August 1787) ; Justices for the City of Oxford (ibid. 12th A pril 1788).

${ }^{4}$ Surrey Quarter Sessions (see Public Advertiscr, 17th August $1787)$. 
other hand, the Wiltshire magistrates in the Salisbury Division hit upon the idea that "common brewers, being the owners of public-houses, should be themselves securities for the good conduct of their tenants." 1 Many benches adopted a formal resolution to grant no "new licence to any public-house but where the convenience of the public absolutely required it "; or "excepting the case where some other house in the same parish or place shall have been suppressed within the preceding twelve months" ${ }^{3}$ or " until the present number shall have been considerably reduced, ${ }^{4}$ or for any house "situate upon the skirts or outparts of any village," 5 or to any person intending to set up a dram-shop, ${ }^{6}$ and in any case to insist on four weeks' notice prior to the Brewster Sessions, in order to enable inquiries to be made. ${ }^{7}$ The Nottinghamshire

1 Justices for the Salisbury Division of Wilts (see Bristol Journal, 29th September 1787).

${ }^{2}$ For instance, Oxfordshire Quarter Sessions, 10th July 1787 (see Bristol Journal, 15th September 1787).

3 Suffolk Quarter Sessions (see Ipswich Journal, 1st September 1787); Essex Quarter Sessions, 23rd July 1787 (see Chclmsford Chronicle, 2\%tlu July 1787).

4 West Riding Quarter Sessions, 16th April 1787 (see Lecds Intelligenecr, 1st May 1787).

5 Nottinghamshire Quarter Sessions (see Nottingham Journal, 21st July 1787).

6 West Riding Quarter Sessions (see Lceds Intelligencer, 16th May 1786) ; Surrey Quarter Sessions (see Public Advertiser, 17th August 1787 ).

7 West Riding Quarter Sessions (see Lceds Intelligcncer, 16th May 


\section{LIQUOR LICENSING IN ENGLAND}

Justices declared their intention of refusing to grant a spirit licence to any person who did "not sell any wine, chocolate, coffee, tea, ale, beer, or other liquors." 1 The Essex Justices made up their minds, "with mild firmness . . . gradually at least, to licence no alehouses occupied by persons carrying on some other business; to lessen the number, so as to make each the means of a decent support to a worthy family and consequently a heavy loss to be forfeited by an omission of the conditions on which such a beneficial licence is granted; and to receive no certificate of recommendation of character for licence unless signed, together with the other inhabitants, by the officiating minister of the parish, if resident in the same." " The magistrates of the borough of Leeds resolved in 1790 that they would "not on any account, or upon any solicitations whatever, grant any licence for the opening any other house as an alehouse than those that are at present licensed;

1786). It became customary for the magistrates to notify, by public advertisement prior to each Brewster Sessions, that they invited complaints or information from any person as to misconduct committed by any licenee-holder. See, for instance, Public Advertiser, 20th Angust 1787; Lecls Intelligencer, 26th A pril 1790, and 23ril April 1792. In 1792 (by 32 Gcorge III. c. 59) the Justices' consent was first recuircd for the transfer of a licence.

1 Nottinghanshire Quarter Sessions (see Nottingham Journal, 21st July 1787).

2 Chelmsford Chronicle, 24th August 1787. 
and that as the keepers of such small alehouses in the borough either cease to keep publichouses, or remove out of the borough, or die, the magistrates are determined to reduce the present number of these houses. Any person or persons, therefore, purchasing a licence or licences, or entering upon any licensed public-house at any intermediate part of the year for which the licence is granted, will do the same at his or her peril of being refused a licence." 1

But the Justices did more than refuse new licences, and forfeit those of publicans who had broken the law; they, like their predecessors of two centuries before, used their power to insist on quite new conditions of carrying on the trade.

In Newcastle-on-Tyne the alehouse-keepers were given "a printed copy of rules for their guidance, together with a printed copy of His Majesty's proclamation for preventing and punishing vice, profaneness, and immorality," and the licences were declared to be void "upon breach of any one of the printed rules so delivered," when the recognisances were also to be estreated; and every alehouse-keeper was expressly required "to keep the aforesaid two

1 Borough Justices' Meeting, 3rd May 1790 (see Lceds Intelligencer, 11th May 1790). This resolution was repeated two years later (ibid. 18th June 1792). 
printed copies constantly langing up, either in frames or pasted on boards, in the most proper and conspicuous place in his or her house, where all persons resorting to the house may read the same." " What these conditions were we learn in other cases. In many counties the Justices made it a condition of all licences that the publichouses should be closed at mine o'clock in winter and ten o'clock in summer. ${ }^{2}$ At Leeds, the Borough Justices fixed ten o'clock as the closing hour all the year round. ${ }^{3}$ More or less Sunday closing became the rule everywhere out of London. The publicans in Manchester "had notice that no liquor must be sold before noon on Sundays" ; ${ }^{4}$ whilst those of Gloucestershire

\section{Ipswich Journal, 24th May 1788.}

2 Oxford Quarter Sessions, 10th July 1787 (see Bristol Journal, 15th September 1787) ; Berkshire Quarter Sessions (see Northampton Mercury, 8th September 1787; Lcels Intelligcncer, 18th September 1787); Gloucestershire Quarter Sessions (see Bristol Gazette, 24th January 1788).

${ }^{3}$ Borough Justices' Meetiug, 3rd May 1792 (see Lccds Intclligencer, 18th June 1792). At Derby no closing time seems to have been fixed until 1799, and then only for Saturlays, when all public-houses were directed to elose at 11 P.M. (see Derby Mercury, 21st November 1799). The Mlayor of Plymonth printed a handbill in 1809, warning licensed vietuallers that they must elose at $10 \mathrm{P}$.M., and must not allow persons to remain tippling, or serve night-watehmen (Fol. Mise. Papers, 1800 to 1835 , l. 53, in Plymonth Corporation MS. Records).

${ }^{4}$ Bristol Journal, 22nd September 1787. At Stock port there was a similar prohibition up to half-past twelve (Report of House of Commons Committee on the Sale of Beer, 1833, p. 238). 


\section{REGULATION AND SUPPRESSION 61}

were directed not to serve on Sundays any one but travellers " until after the evening service," and then only up to eight o'clock. " In other counties all houses of public entertainment were to cease selling drink during the hour's of divine service, during which time no one was to be received or remain in such houses. ${ }^{2}$ The Leeds Justices drew a queer distinction between beer, which was not to be sold during divine service, and "drams" (of spirit), which were not to be sold on Sundays at all. ${ }^{3}$ The Berkshire Justices went further, and enforced complete Sunday closing, except for the "bona-fide traveller," making it a condition of all their licences, "that on the Lord's Day they do not receive, or suffer to remain, any persons as guests to tipple, eat, or drink, other than travellers, or such as come

1 Gloucestershire Quarter Sessions (see Eristol Journal, 24th January 1788).

2 Essex Quarter Sessions, IIth July 1786 (see Chelmsford Chronicle, 28th July 1786); Oxfordshire Quarter Sessions, 10th July 1787 (see Bristol Journal, 15th September 1787) ; Derby Borough Justices (see Derby Mercury, 21st November 1799); Nottinghamshire Quarter Sessions (see Nottinghum Journal, 21st July 1787). It was the same desire for Sunday closing that led to the direction that no stagewaggon or cart was to be received at any time on Sunday, and the publican was required, at his peril, promptly to inform against the owners of public rehicles so breaking the Sabbath, so that they could be prosecuted. Oxfordshire Quarter Sessions, 10th July 1787 (see Bristol Journal, 15th September 1787).

${ }^{3}$ Borough Justices' Meeting, 3rd May 1792 (see Leeds Intelligencer, 18th June 1792). 
upon necessary business." 1 Another revival of the "articles" of the beginning of the seventeenth century was the rule, adopted by Gloucester and many other counties, that one hour should be the maximum time that "any journeyman, labourer, servant, or apprentice" should "remain tippling"; and that if such a person was allowed to remain more than that time, or should become intoxicated by tippling for less than that time, the alehouse-keeper would be deemed guilty of an offence against the Statute of $1603 .^{2}$

It is significant that the Justices of the Peace of the latter part of the eighteenth century - frequently cited as the most oligarchical and autocratic of governing authorities-habitually made use of local option or local reto in their administration of the Liquor Laws. The Act of 1753 had, as we have seen, required every applicant for a licence, except in corporate towns,

I Berkshire Quarter Sessions (see Northampton Nercury, 8th September, and Leels Intelligencer, 18th September 1787).

2 Gloncestershire Quarter Sessions (see Bristol Gazette, 24 th January 1788). A new instrument of order was found by some rural parishes, in which the Vestry oftered a reward of two or three guineas to any person giving information lealing to the eonviction of any person "for selling beer or spirituous liquors within the said parish withont a lieence" ; so at Saxmuntham, Great Glemham, and Swaflling (see Ipswich Journal, April, May, and June 1788; and other eases in Suffolk). Lirby and Walton (Essex) (see Chelmsford Chronicle, 9th May 1780). This policy was approved by the Sullolk Quarter Sessions (see Ipswich Jonrual, 18th Oetoher 1788). 
to support his application by a certificate of personal character, signed either by the clergyman and churchwardens, or by three or four householders. The Gloucester Justices bettered this statutory requirement by requiring the certificate to be in all cases signed by the clergyman and principal inhabitants of the parish, and directing that it was to be signed "at a vestry to be called for that purpose with proper notice." ${ }^{\prime}$ That the consent of the "principal inlabitants in vestry assembled" became, during the next two decades, a necessary condition of the granting of new licences in many counties is proved by the vestry records. Thus, in the lively little town of Brighthelmstone (Brighton), we find the question of whether or not new public-houses should be licensed becoming the subject of prolonged agitation. In 1801 a "public vestry" was held "to take into consideration the propriety of licensing a rictualling house situate at the back part of the Royal Crescent." The clergyman who presided succeeded in persuading the meeting to resolve "that it is the opinion of this meeting that there are already public-houses enough in the town of Brighthelmstone for the convenience of

1 Gloucestershire Quarter Sessions, Eliphany, 1788 (see Bristol Gazette, 24th January 1788). 
its inhabitants and the good of the trade, and that the increase would be ruinous to the trade and principally injurious to the lower class of people." " Three years later we find the Chief Constable, whom we suspect of being friendly to the publicans, presiding over another public vestry, duly summoned by notice in church for the express purpose, which resolved "that it appears to this meeting that there are already forty-two public-houses in the parish," but that these are "not sufficient for the accommodation of the parish," and that accordingly five named persons are recommended to the Justices as eligible to receive licences. ${ }^{2}$

Even more revolutionary was the practice of calling into council the "principal inhabitants" of the parish as to the expediency of renewing the old licences. The Justices for the Bathsorum Division of the county of Somerset "recommend it to the Ministers and Clumrehwardens to be careful in inquiring into the characters and behaviour of publicans within their respective parishes; to

1 MS. Vestry Minutes, Brighthelmstone (Sussex), 2tth February 1801 .

2 I bial. 24th August 1804. Another vestry meeting a week later recommenels six additional persons for licences (ibid. 31st August 1804). In the eity of London it was apparently the eustom to require the support of the Aldermen and Common Councillors of the particular ward before a new licence was granted (Reprort of House of Commons Committee on the Sale of Beer, 1830, 1. 16). 


\section{REGULATION AND SUPPRESSION 65}

point out to us where there are too many publichouses for the reasonable accommodation of the neighbourhood, and by no means to recommend the licensing of new ones without very sufficient cause for so doing, as we are determined to keep a watchful eye particularly over that part of the police." 1

\section{Elsewhere the practice of requiring local}

1 Bath Chronicle, 16th Angust 1787. We see the effect of such a circular from the Justices in the following ease :- " The parish officers of Frome," we are told, "have determined not only to see that good order is kept in the public-houses on Sundays, but at all other times, particularly on Saturday nights, which are generally appropriated to drunkenness and dissipation; and to report such houses to the Justices as are not shut at ten o'clock" (Bristol Journal, 10th September 1787).

What happened in :n energetic Vestry we may gather from the following report of the proceedings at Wanstead (Essex):- "At a Vestry held at the parish church of Wanstead for the furpose of carrying into effect the objects proposed by His Majesty's late proclamation, it was resolved that the . . parish oflicers and police officers be required to pay particular attention to the conduct of the sereral keepers of public-houses within this parish, and that they make their report to the Vestry concerning them ; whether they keep good order; whether they suffer gambling or tipuling at unseasonable hours; whether they have any skittle grounds or any place or instrument for gambling of any kind; and especially whether they keep their houses open for the entertainment of their guests in the time of Divine Service on the Lord's Day.

"That a Vestry be held on the last Sunday in August for the purpose of receiving the said report.

"That the constables be required to visit the public-honses within this parish at ten o'clock every night, and see that the publican dismiss his guests and shut up his honse at that hour; and that they take into their custody all such persons as shall refuse quietiy to depart when called upon by the constables and publicans so to do" (Chelmsford Chronicle, 10th August 1787). 
consent was systematically applied to all the existing licences. Thus the Justices of the Bampton Division of Oxfordshire publicly notified in August 1787 that they would, at the next "Brewster Sessions," require in all cases fresh certificates, not merely as testimony to character by any three or four householders, but " under the hands of the Minister, Churchwardens, and at least six of the principal inhabitant householders (if so many there be) of their respective parishes . . asserting the expedience and necessity of such house to be licensed, without which certificate no licence will in future be granted." ${ }^{1}$ 'The North Riding Justices laconically request the ministers of all the parishes in the Riding "to state how many alehouses they think necessary in their respective parishes." 2

More specific were the West Riding Justices who resolved, at Michaelmas 1787, to hold annually at Easter in each division an adjourned Brewster Sessions, for the special purpose of inquiring into "the state and situation" of

'Jackson's Oxforl Journal, 18th August 1787. Fresh certificates were also called for hy the Justices for the Woodbridge and Ipswich and Beeeles divisions of Suffolk (see Ipswich Journal, 1st Sept. 1787; and 3rd May 1788), and by those of the county of Durhan (see Newcastle (hronicle, 18th August 1787).

${ }^{2}$ North Riding Quarter Sessions, 10th July 1787 (see Leeds Intelligeneer, 7th August 1787). 
all the licensed houses, prior to which "the Minister and Churchwardens of every Township" were "to call a meeting of the overseers of the Poor, Constables, and all the Principal Inhabitants of their Townships for the express purpose of making a return to the Justices of such public-houses as they, or a majority of them, shall think useful and necessary, and also of such others as are either improperly situated, or on account of the past irregular and disorderly conduct of the occupiers they would wish to have suppressed in future." 1

1 West Riding Quarter Sessions (sce Lecls Intelligenee, 9th October 1787). We hare a vision of this local option at work in the following letter from the Rector of Twerton (Somerset). "In the year 1786 I addressed a letter to the Justices of the Peace for the Division of Bathsorum, stating the inconvenience which the parish of Twerton (of which I am the minister) laboured under from the number of public-liouses. I alleged no instance of misconduct against either, but the Justices were pleased to suppress two out of three : a circunistanee with which I was highly gratified, being convinced that one was fully sufficient for the accommodation of the neighbourhood. My parishioners thought otherwise, and constantly expressed their wish that another house or houses should be licensed. I was frequently applied to by the owners of the suppressed houses to join in recommending them to the Justices, but I uniformly declined to interfere in the business. When the time for renewing the licences approached, these solicitations were repeated, and I even received applications from several persons of credit both in Bath and Bristol in bchalf of the respective houses, with the assurances that it was the wish of my parishioners that they shoukl be licensed, and that the Justices wonld not grant a licence to either unless I would sign the recommendation. To these applications I replier that if a majority of my parishioncrs were in favour of another public-house, I would join them in recommending whichever of the two they should 
From the standpoint of the present day the most notable action taken by the magistrates was the drastic suppression up and down the country of public-houses, without compensation, sometimes because these were complained of as disorderly, as ill-constructed, or as improperly situated, but frequently because they were deemed superfluous - affording injurious encouragement to the consumption of intoxicating drinks. "At the Petty Sessions held here," we read of Gloucester in 1786, "a petition was pre-

think most proper, provided they would agree to recommend only two at this or any future period. At this time a printed paper was delivered to me signed by the Justices of the Peace, purporting their intention to exert their authority for accomplishing the desirable objects of His Majesty's proclamation, and recommending to the Minister, Churchwardens, ete, in every parish to use their utmost caution in the recommendation of publie-houses. I, therefore, at a meeting of the principal inhabitants of the parish, recommended this paper, as well as the King's proelamation, to their partieular atten. tion. I then made the deelaration above mentioned, and added as an alditional eondition that they should never sign any recommendation or certificate for a publiean but at a meeting of the parishioners called for that purpose. . . The persons present at this meeting were unanimous for another public-house; they readily acceded to the conditions I had proposed, and resolutions were aecordingly entered in the parish book to that purpose. They were also unani. mous in recommending the Crown public-house, together with the one lieensed the former year. The reason assigned for their preference was that the person who was to keep it was well known to them. . . I I aceordingly signed a recommendation for the houses above mentioned." The Justices, it seems, aecepted the parish deision as to the number, and licensed two public-houses. But they had not intended a local popular election of publicans, and chose another person as the holder of the second licence (Bath Courunt, 18th October 1787). 
sented to the Justices by the principal inhabitants of the parish of Pitchcombe, stating that their poor's rates before the licensing an alehouse in the parish were two shillings in the pound, but since two alehouses had been opened the common people have become idle, drunken, and profligate, and have spent their wages in the public-houses, leaving their families to be supported by the parish; by which means the rates have lately risen to eight shillings in the pound." Upon this representation the Justices suppressed both the alehouses. ' The Gloucestershire Justices were evidently in earnest. "Last year," it was said, "no less than ten alehouses were licensed in the parish of Horseley, near Gloucester. The Justices have now reduced them to three." 2 A Somersetshire correspondent writes in 1787 : “ We learn that the licences of six public-houses in the parish of Widcomb, the 'Blue Lodge' in the parish of Weston, and several others, were suppressed by the Justices of Bathsorum Division (Somerset) at their late meeting." " "We hear from Holywell," says another, "that, at the meeting for licensing public-houses held there, the magistrates, to give force to His Majesty's proclamation, refused the

1 Leeds Intelligeneer, 26th Sepitember 1786.

2 Ibid. loth October 1786.

${ }^{3}$ Bristol Journal, 22nd September 1787. 


\section{0}

\section{LIQUOR LICENSING IN ENGLAND}

renewal of licences to eight public-houses in the town, and several others within their district, which they deemed superfluous, and tending to the inerease of immorality and debauchery." 1

"We are informed that the magistrates have refused licensing seventeen public-houses in Speen Division of Berkshire, and that the magistrates for Wiltshire have put down fifteen publichouses in one division in that county." 2

That the refusals to renew old licenees were persisted in we learn from the instance of a northern city. "Tuesday last," it was reported in 1789 , "the ale lieences were granted for the city of Carlisle by the Earl of Lonsdale and the Mayor, but the innkeepers who were refused the last year were again denied." 3

Even stronger action than the suppression of a few unnecessary village alehouses is recorded of the West Riding Justices in the case of a large manufacturing centre. The rapidly growing town of Sheffield, with a rough and turbulent population of eutlers, file-makers, and miners,

${ }^{1}$ Bristol Joumal, 6th Octoher 1787.

2 Ibid. 22nd September 1787. A week later it is reported that, at the Brewster Sessions of the Justices for the Salisbury Division of Wilts, "several houses of notorions character were suppressed, and some useful regulations adopter. . . . Returns were made to the Justices from many parishes of the publie-houses therein, and the eonduct of landlords" (ibid. 29th September 1787).

3 Newiestle Chronicle, 3rd October 1789. 


\section{REGULATION AND SUPPRESSION 71}

had suffered specially by the multiplication of "dram-shops," which, like those of London, sold large quantities of cheap gin and other spirits. The magistrates acting for that division of the West Riding began by closing them on Sunday, and three months later took the strong step of suppressing them all at one fell swoop. ${ }^{2}$ The Devon county magistrates in 1805 took drastic action at Plymouth Dock (now Devonport), at that date thronged with sailors and dockyard workmen, and the largest town in the west of England. Every street had its own series of public-houses and beer shops, which vied with one another in offering music, dancing, and other attractions to attract custom. The 24,000 inhabitants had enjoyed over 200 public-houses, which the Justices suddenly reduced to 100 , at the same time ordering each "inn" to have a lamp over its front door, and each "tavern" two lamps. ${ }^{3}$

1 Leeds Intelligencer, 26th June 1787.

2 "At the Brewster Sessions held at Sheffield yesterday s'en night (10th September), before the Justices of the Peace for this Riding, a total suppression was ordered of the numerous dram-shops in that town, by withholding from them ale licences, which, according to the Act in that respect made, restrains them from selling less than two gallons of any kind of spirituous liquors" (Leeds Intelligencer, 18th September 1787).

${ }^{3}$ History of the Toun and Borough of Devonport, by R. N. Worth (Plymouth, 1870, Pl). 20, 36). We may add that, abont 1818, the publicans of the neighbouring borough of Plymouth petitioned the 
It might reasonably be assumed that so essentially a national movement in favour of regulation and restriction could not fail to influence the metropolis. We do, indeed, find the Justices for the St. James's Division of Westminster deciding, as early as 1785 , to adopt a stringent policy. They resolve that the "constables and beadles do return lists of the names of all victuallers and other persons who shall set up or keep any bawdy-house, or house of ill-fame, or shall permit, suffer, or set up any E.O. table, billiard, or other gaming-table, or any shuffleboard, or suffer any skittle-playing." They threaten to proeed against any publican who "shall keep his or her house open in the night or suffer any drunkenness or tippling, or any daneing or music." They resolve "where any licensed victualler is convieted of any of the offences aforesaid, that no licence be afterwards granted to the house where the offence was committed." They declare " that there are too many licensed houses in this parish," and "that the number ought to be reduced . . that no

Mayor for a revocation of a reeent order forbidding music and dancing in public-houses. The petitioners deelare that, should the soldiers' and sailor's" "favourite entertaimment of a fidule and a danee be withheld from them, the houses will be entirely deserted, and your petitioners will be ruined" (Fol. Misc. Papers, - 77 , in Plymonth Corporation MS. Recorls). 


\section{REGULATION AND SUPPRESSION 73}

licence be granted on any pretence whatever to any house not licensed the preceding year ... and that whenever it shall appear to the satisfaction of the magistrates that there is not sufficient custom to a house for the victualler to get a livelihood, that the licence be not renewed the next year." 1

That these resolutions were acted upon we learn in 1787, when it is reported that "the magistrates have refused licences to several public-houses; they have also caused all the other regulations to be carried into execution, and continue to meet, as formerly, three times a week to receive complaints and grant redress." 2

The Justices of the Kensington Division of Middlesex were stirred into activity by a local tragedy. "Two men at an alehouse in the King's Road, between Fulham and Chelsea . . . drank gin to such an excess that one of them, a gardener in that neighbourhood, died beastly intoxicated a few minutes after he drank the last half-pint. . . The magistrates in that division have since, at a general meeting, refused to renew the publican's licence, and have also, to their credit, begun the good and necessary

1 Justices for the St. James's Division of Westminster, 7 th September 1785 (see Morning Herald, 11th August 1787).

2 Morning Herald, 11 th August 1787. 


\section{LIQUOR LICENSING IN ENGLAND}

work of reformation by stopping the licences of forty-three useless and improper public-houses in the parishes of Fulham, Chelsea, Hammersmith, and Kensington; and however strange it may appear, there is at this time twenty-one licensed public-houses within the space of one mile fronting the road in the parish of Hammersmith." 1

Here and there we find a Metropolitan Vestry protesting against the licensing of this or that public-house, or taking action-possibly instigated by the local Justices-to enforce order on licensed premises. Thus, in July 1787, we see the Fulham Vestry earnestly recommending "to the constables and head borough of this parish to be diligent and regular in searching the publichouses, particularly on Sundays; and if any shall be found where tippling is suffered during the time of Divine Service, or gaming or any other disorders or irregularities at any time, to give notice thereof to the magistrates resident in this parish to the intent that the persons keeping such houses may not be again licensed." 2

The records of the Marylebone Vestry show that it had occasion to oppose the renewal of

1 Gazetteer and New Daily Advertiser, 10th September 1787.

2 Vestry Minutes, Fulham (Middlesex), sth July 1787, in Fulham, Old and New, by C. J. Féret (1900), vol. i. p. 26. 


\section{REGULATION AND SUPPRESSION 75}

licences to persons of bad character. Thus, in 1800, "the Vestry having been informed that application had been again made to the magistrates acting for the Holborn Division for the renewal of the licence to the public-house called the 'Wheatsheaf' in Callmel Buildings in this parish, which had been refused last year on account of the many irregularities committed in the said house by gamblers and other persons of the most abandoned characters, resolved unanimously, that in consideration of the advantages already derived to the peaceable inhabitants of that neighbourhood, and of those likely to accrue to them in future, should the licence be refused, it be recommended to the magistrates at their adjourned meeting not to renew the said licence." 1 In 1795 " J. B., keeper of the public-house known by the sign of the Elephant and Castle, in Oxford Market, according to notice for that purpose, attended to answer a complaint against him for suffering disorderly persons to tipple in his house at unseasonable hours." After a severe warning, the Vestry "dismissed the complaint." 2 But making due allowance for these and other instances, we cannot refrain from noticing that,

I MS. Vestry Minutes, Marylebone (Middlesex), 13th September 1800 .

2 Ibid. 9th June 1795. 


\section{LIQUOR LICENSING IN ENGLAND}

in spite of the greater publicity ensured by the London newspapers, our seareh has brought to light eomparatively little in the way of activity, the regulation or restriction of liquor licensing, either by the Vestries or by the Justices of the Peace who had under their government the populous parishes of the metropolis. The remarkable movement for greater stringency which swept over the provinces appears scarcely to have touched the metropolis. The notorious "trading justice" of Middlesex, who, to quote a contemporary, "turns the exercise of his authority into an iniquitous traffic," " had, by the establishment of the publie police-offices, lost the particular opportunities for "creating business for his own emolument," deseribed by Fielding. No general proclamation against vice and immorality was likely to prevent him, at the Brewster Sessions, from creating valuable property for his creatures and friends, by merely signing his name to new alehouse licences. Hence it is not surprising to learn on excellent authority that the habitual practice in Middlesex was for licences to be "granted with great faeility, and far beyond what appears to be necessary for the public accommodation, and in some instances in direct violation of the laws of

1 Enquiry into the Duties of Men, by Thomas Gisborne (1794), 1. 287. 
the land." 1 The same authority tells us that the licences of "completely infamous" houses were renewed in spite of the protests of the police officers and the principal inhabitants. When additional stipendiary magistrates were appointed in 1792, they seem at first to have attended the licensing sessions, and to have brought to notice " the ill-regulated public-houses conducted by men of loose conduct and depraved morals." ${ }^{2}$ But "perceiving the inutility of those efforts," with the little coterie of Justices who had assumed all the licensing duties, they "ceased attendance" at the Brewster Sessions." The ablest and strongest of the new stipendiaries, the celebrated Dr. Patrick Colquhoun, did, indeed, work a temporary reformation in the Tower Hamlets. In 1792, among a total of 1100 public-houses in the division, he managed to get suppressed 87 of the worst gin-shops. ${ }^{4}$ But any such suppression was quite exceptional. "Once a public-house always a public-house," and "bricks and mortar commit no sin," were favourite axioms of the Middlesex bench. If

1 Report of House of Commons Committee upon the Police of the Netropolis, 1816, p. 97.

2 Treatise on the Police of the Metropolis, by Dr. Patrick Colquhoun (1800), p. 324.

${ }^{3}$ Report of Committec upon the State of the Police of the Metropolis, 1816, p. 96.

${ }^{4}$ Ibid. 1. 50. 
one occupier misconducted himself, it was for the brewer to put in another.

There was, however, one direction in which the metropolitan Justices seem to have exercised their regulative powers. Ever since the terrifying orgies of the earlier decades of the eighteenth century there had remained, in the minds of all thoughtful persons, a strong desire that the people should give the preference to beer over spirits. The evidence before the committee of 1816-17 shows that the Middlesex magistrates thought that they were only carrying out the policy implied in the Acts of 1743-53, in insisting that the public-houses licensed by them should be and continue, in the main, alehouses, providing accommodation for social intercourse; and should not be converted into mere "bars," for the sale of spirits to a constant stream of persons seeking only an intoxicant. ${ }^{1}$ It was this policy of discrimination against the incipient "gin palace," somewhat unintelligently pursued by the Justices, that was sarcastically described

1 The magistrates who, as it was said, had "imbibed the principle laid down in the preamble of the Act of 9 George II. (1736), objeeted to the publieans having a separate door to a shop fitted up with barrels and inseriptions to show the great consmmption of the gin and cordials, with a long counter, and syphons to draw up the varions liquors with expedition for the customers who come in and ont, . . . thus giving incitement to the excessive use of spirituous liquors" (ibid. p. 188). 
by a hostile critic in 1816 . The Middlesex Justices, he said, instead of enforcing publicity and responsibility, had lost themselves in a maze of arbitrary distinctions between "taprooms and pewter counters, tobacco pipes and brass cocks, checquers and glass phials." "

1 Report of Committee upon the State of the Police of the Metropolis, 1817, p. 63. In spite of the growing objection to magisterial interference with the conduct of the trade, this policy was persisted in ; and in 1816, and again in 1829, it was resolved by the Middlesex Quarter Sessious that "The Court taking into consideration the increasing use of spirituous liquors amongst the inferior ranks of people of both sexes within their jurisdiction, so destructive to their health and morals, and attributing it in a great measure to the facility and privacy by which the liquor may be obtained through the means of houses licensed by the Justices to sell beer, but which are appropriated either solely to the purpose of retailing spirits, or have rooms, fitted up for this use only, that communicate directly with the street, or with some court or alley adjoining it," in violation of the Act of 1753, recommends the Justices in Brewster Sessions not to license any publican who shall be found to bave obtained an alehouse licence as a mere pretext for obtaining a spirit licence; nor any person "who cannot prove to thcir satisfaction that he has sold in his house during the preceding year a reasonable quantity of malt liquor, respect being had to its size and situation ; and that he has a public tap-room in front of his house, fitted $u p$ and frequented for that purpose" (MS. Minutes, Quarter Sessions, Middlesex, July 1816 ; rcpeated verbatim, 29 th October 1829). The same policy was adopted by the Surrey Justices, who resolved "not to license any house which had not good accommodation for such persons as should prefer beer to spirits, and good beer to furnish them with" (see report in Hull Packet, 23rd January 1816). It was violently denounced by the licence-holders as an arbitrary interference with liberty and property (see Suggestions and Corresponlence relative to Magistrates' Licences, arranged by H. B. Fearon (1830), one of the principal ginsellers of the Metropolis, preserved in the Place Papers, Additional MSS. 27829-40; also Report of House of Commons Committee on the Sile of Beer, 1830, p. 95-116). 
How energetically and how long the various county benches carried out the policy of restriction and regulation, started in 1786-87, we cannot exactly diseover. After the end of the eighteenth century the general meetings of magistrates at Quarter Sessions, of which alone records or reports exist, seem to have ceased to concern themselves with licensing; and the new policy may have been quietly either continued or abandoned by the Brewster Sessions. When again the Justices' action becomes a matter of public controversy, namely, from 1816 to 1830 , the complaints against them are principally that they refuse new licences or arbitrarily withdraw old ones; and from this fact it is not unreasonable to infer that the old indiscriminate granting of licences had not been resumed. Still more difficult is it to ascertain with any accuracy what were the results of this restrictive policy. We cannot even get statistics as to the total number of alehouses licensed, or the number of licences withdrawn. 'The number of alehouses in England and Wales, vaguely supposed in 1773 to be about 40,000-plainly an underestimate ${ }^{1}$ —was

1 A eonsiderable proportion of the alelrouses, ineluding apparently the majority of those in the rural distriets, had no spirit licence; yet there were in 1779 no fewer than 37,172 houses licensed for the retail sale of spirits (Appendix $32 a$ of First Reprort of Commissioners of Inland Revenue, 1857). We suspeet that, at this date, there were 


\section{REGULATION AND SUPPRESSION 81}

found in 1810, when the statistics begin, and when the population had greatly risen, to be no more than 48,000 . The effect of the movement of 1786-87 can, however, most clearly be seen in the number of houses where spirits were sold, of which accurate statistics exist. In spite of the rapid growth of population, and its aggregation in new centres, the total number of publicans' spirit licences in England and Wales, which reached a high point in 1779 , shows the following reductions in the next decade $:^{1}$--

$\begin{array}{llllll}1779 & . & . & . & & 37,172 \\ 1780 & . & . & . & . & 36,712 \\ 1781 & . & . & . & . & 36,033 \\ 1782 & . & . & . & . & 34,923 \\ 1783 & . & . & . & . & 34,329 \\ 1784 & . & . & . & . & 35,176 \\ 1785 & . & . & . & . & 35,697 \\ 1786 & . & . & . & . & 36,029 \\ 1787 & . & . & . & . & 36,675 \\ 1788 & . & . & . & . & 34,503 \\ 1789 & . & . & . & . & 33,349 \\ 1790 & . & . & . & . & 32,850\end{array}$

The population went on increasing by leaps altogether not less than 100,000 licensed houses for a population of fewer than eight millions.

1 See Appendix No. $32 \alpha$ of First Report of Commissioners of Inland Revenue, 1857. The drop' in 1789-90 is probably to be ascribed, in part, to the rechction of licence duty which took place in 1788 . 


\section{LIQUOR LICENSING IN ENGLAND}

and bounds, but the number of spirit licences went on sinking, until in 1799 it was only about 30,000 , or fewer than in any year since 1769 . From 1799 the numbers rose very slowly, at the rate of about 1 per cent per annum, until in 1825 they reached 38,472 , or hardly more than the number granted by the Justices of 1779 for two thirds the population. Meanwhile the number of alehouse licences had, between 1810 and 1825 , actually remained nearly stationary, at about $48,000 .{ }^{1}$

Owing to the amount of private brewing, and the illicit distillation and smuggling of spirits, no trustworthy statistics can be given as to the total consumption. There is, however, a certain amount of testimony that the average consumption of alcoholic drinks diminished during this period, a diminution which the authorities declare to have taken place among the "lower orders." And it is interesting to record that our own researches into the history of crime for this same period, concluded prior to our discovery of this movement for the regulation and restriction of the sale of alcoholic drinks, had already caused us to note what we termed a "lull" in crime and rioting, licentious

1 See the tables at 1]p. 44 and 60 of Thirteenth Reprort of Com. missioners of Inland Revenue, 1870. 
living, disorderly conduct, and brutal amusements between 1790 and 1810 . We entertain no doubt that, compared with the immediately preceding period, there was in England, during these years, a marked diminution of overt acts of crime and disorder. We had suggested that this might possibly have been due to the absorption of disorderly characters in the army and navy during the years of war, and to the greater regularity of life introduced by the factory system. Both these circumstances, and others that might be cited, seem to us to afford an inadequate explanation. Any good effects they may have had were probably more than counterbalanced by the demoralisation of large sections of the population by the worst features of the Old Poor Law, which became prevalent in 1795 , and by the terrible stringency of the famines and high prices of these very years. Our subsequent discovery of the regulation and restriction of the sale of alcoholic drinks carried out by the Justices from 1786-87, and lasting, as we infer, in many parts of the country for a whole generation, appears to us to throw new light on the subject. We think that any impartial student of the contemporary records will be driven to the inference that the limitation of the opportunities for disorderly drinking 


\section{LIQUOR LICENSING IN ENGLAND}

between 1787 and 1825 outside the metropolis was at any rate an important contributory cause of the remarkable advance in "respectability" made by the English working-man during the first two decades of the nineteenth century. 


\section{CHAPTER IV}

FREE TRADE IN THEORY AND PRACTICE

IN the opinion of the country Justices of the Peace, concerned for the good order of their villages and, as we may believe, for the reformation of the manners and morals of the people, the regulative and restrictive policy of 1786-87 had proved a distinct success. It is therefore with surprise that the student finds this policy, from 1816 onwards, meeting with almost universal condemnation.

To the Whigs, and still more to the rising school of philosophic Radicals, the arbitrary authority vested in the Justices of the Peace was in itself an offence. They vehemently resented the fact that unrepresentative bodies, like the magistrates in Brewster Sessions, could, without appeal, deprive the working-man of his beer, the honest publican of his means of livelihood, and the brewer of his property, out of mere caprice, and not without grave suspicions 
86 LIQUOR LICENSING IN ENGLAND

of political partisanship ${ }^{1}$ and even pecuniary corruption. There was at this time nothing in the nature of a temperance party, and though the vice of drunkenness was deplored, beer was still habitually regarded as a necessary of life, and any idea of interfering with individual liberty was more abhorrent even than drunkenness itself. The Tories, on the other hand, did not see any objection to the authority of the Justices, which, haunted by the spectre of the French Revolution, they would willingly have strengthened. But they had a sentimental objection to any interference with the pleasures of the people. Some of them may have thought, like Wyndhan, that if the lower orders were rendered less self-indulgent, they would become more seditious. The Tory leaders were at any rate so desperately keen on maintaining the authority of the Government against the rising tide of reform, that they were, after 1825 , not disposed to lose any popularity by restraining the common people from their sensual and brutalising anusements.

I The publican at the beginning of the nineteenth century was apparently usually a Radical. "The public-houses resorted to by the lower elasses," we read in 1800, "particularly in the metropolis, though under the immediate control of the magistrates, almost invariably take in newspapers of a pernicious tendency" (Reflections on the Moral and Political State of Soeiety at the Close of the Wighteenth Century, by John Bowles, 1800, P. 161). 
Finally, we have to take account of what seems, between 1820 and 1830, to have become almost an obsession of the mind of every enlightened legislator, Tory and Radical alike, that every person ought to be left free to invest his capital and employ his talents in whatever way he thought best; that cheapness and good quality could only be secured by an absolutely unrestricted competition; and that there was no reason why the number and position of publichouses should not be left as free as those of bakers' shops. All these abstract doctrines found illustrations and arguments in two undoubted facts, the rapid growth of a monopoly of public-houses in the hands of the great brewers, and the proved corruption of the Justices in one or two divisions of the metropolis. These facts were brought to light by a remarkable series of Parliamentary inquiries into the "police" of the capital during the years 181618. In the Parliamentary proceedings of the ensuing decade the personal grievances and public wrongs alleged to be caused by the arbitrary action of the Justices and the brewers' monopoly recur with monotonous iteration.

It is not our business here to enter into the history of the industries of brewing and distilling, 
or to describe the gradual development, from the latter part of the eighteenth century, of the oldfashioned "family brewers" into gigantic establishments supplying the whole world. Nor can we explore with any thoroughness the causes and circumstances of one feature of this development, the "tied-house" system, which was, in 1816-30, being energetically complained of. The ownership of licensed premises by brewers and distillers had, as we have seen, been common for more than a century. But increased stringency in licensing undoubtedly increased the practice. When the Justices made it a practice, before granting a licence, to require that the applicant should show that he occupied premises suitable for the business, they insensibly passed into virtually licensing the houses, as well as the particular occupiers. It then became inevitable that the brewers, commanding large capitals, should advance money to enable the necessary alterations to be made, and thus obtain control of a large proportion of the premises on which drink was sold, either by simple purchase of the property or by the publican's indebtedness. ${ }^{1}$ It

1 The purchase of tied houses by the brewers was admitted and defended in 1802 (see Ouservation on Beer and Brewers, by Richard Flower (1802), I' 24-27). Mueh information is given in the Report of the House of Commons Committee on P'ublie Breweries (1818), and the evidence (1819). 
was reiterated on all sides that the limitation of the number of public-houses, their alteration and enlargement to suit the requirements of the Justices, the insistence on substantial sureties for good behaviour, and the general increase of pecuniary responsibility involved in stricter regulation, all fostered the tied-house system. The Justices up and down the country had attempted to counteract this assumed result of their restrictive policy, and to keep alive the old-fashioned alehouse-keeper, free to brew his own beer, or at any rate to buy it where he chose. Thus it was reported in 1816 that "at the late meeting for licensing alehouse-keepers . . in Newbury Division (Berks), the complaints made by the publicans of the badness of the beer served to them by brewers were so general, and in some instances their interference in, and monopoly of public-houses so flagrant, that the magistrates, nine in number, unanimously resolved "that the full extent of time for granting licences should be allowed to several publicans, in order that they might procure other houses, which the Justices would license in lieu of those so monopolised, or wherein any undue interference had been used." I In the following year "the magistrates of the Division

\footnotetext{
1 Comwall Gazette, 21st September 1816.
} 
of Marlborough (Wilts)... refused to grant licences to those who held their houses of common brewers, unless such brewers first declared that they were not bound to take their beer of their respective landlords, except it was good and such as was generally approved of. The magistrates at the same time informed those persons who lield public-houses under brewers that, in case their landlords gave them notice to quit their houses in consequence of taking beer from other brewers, they would authorise them to remove their licence to any other house, and never license such brewer's house in future." I It is needless to say that spasmodic and local efforts of this sort did not deter the agents of the great brewers from seizing every opportunity to purchase public-house property.

The ownership of public-houses by brewers seems to have struck the House of Commons Committee of 1816-17 as a revelation of unsuspected wickedness. They noted, with alarm, that "one half of the victualling houses in the Metropolis" were held by brewers as "owners, purchasers, or equitable mortgagees." In the provinces "it prevailed in a greater degree than in the Metropolis." At Reading, for instance, the local brewers owned or controlled 66 out

1 Carmarthen Journal, 3rd October 1817. 
of 68 licences. $^{1}$ To the House of Commons Committee of 1816-17, the most objectionable feature of this monopoly was not any effect which it may have had on the consumption of drink or social disorder, but " the restricted power which the public at large possess of employing their capital in the trade of victualling houses." 2 The Committee would not inquire whether or not, as a matter of fact, the houses belonging to brewers were better constructed and better regulated than those which were "free"; or whether the commodity which the great brewers supplied as the product of a highly organised industry, using the newest improvements on a large scale, was or was not at least equal in quality and cheapness to that which the old-fashioned little alehouse-keeper had brewed for himself. The evidence on these points brought by the brewers before this and subsequent committees was left unrefuted. ${ }^{3}$ To

${ }^{1}$ Report of Select Committee on the Police of the Metropolis, 1817, 1. 10. An Excise return of 1816 stated that, out of the total of 48,000 licensed alehouses in England and Wales, 14,200 actually belonged to brewers, 10,800 to the occupiers, and 22,700 to disinter. ested persons. This, however, took no account of the "tie by indebtedness."

2 Report of Select Committee on the Police of the Metropolis, 1817, p. 10 .

3 The House of Commons Committee on Public Breweries, 1818-19, dealt specially with these points, and found no evidence that the consumer had been injured. But they nevertheless objected to the monopoly which the great capitalist brewers were obtaining. 
the enlightened members of Parliament of 181630 , it seemed a matter of mere logical inference, from necessary axioms that the more limited the competition of sellers, the worse conducted would be the business, the less would be the accommodation afforded to the public, the higher would be the price, and the more inferior would be the quality. "The eleven chief brewers" of London, it was said in 1818, "met together like partners in one concern and fixed the price of porter." 1 To the dullest intellect on the committee, it was plain that any such meeting would, to quote the classic words of Adam Smith, "end in a conspiracy against the public or in some contrivance to raise prices." This conviction found apparent confirmation in the rapidly rising value of public-house property. The fact that the grant of a licence to a house in a good position in a populous neighbourhood was equivalent to the creation of property worth thousands of pounds puzzled the ordinary members of Parliament. It seemed to them that the exaction of such a price from the purchasers of licensed houses "of course . . r raised the price of everything that was sold in them." 2 Such large investments of capital, they said,

1 Hansard, 1 st May 1818.

2 Report of Select Committee on Sale of Beer, 1833, p. 32. 
" must . . create a necessity of selling at such a price as may secure a trade interest on money so advanced." 1 The House of Commons failed to discriminate between the gains due to an organised trade "ring" of the great brewers; the monopoly value of licensed houses restricted in numbers, by whomsoever owned; and the mere rental value of premises in situations which enabled them to attract an exceptional amount of custom. These three "unearned increments" seemed, to legislators who ignored the teaching of Ricardo, alike explicable only on the supposition that the consumer was being made to pay " an extravagant price" for his beer."

The second fact which influenced public opinion against the restrictive policy of the Justices was the obvious breakdown of the Middlesex bench. This breakdown was, we may here explain, a general one, affecting not licensing alone but all their functions; and resulting, as our investigations show, from the inherent inadequacy of this type of authority for the circumstances of an overgrown capital city. The chairman of the committee, a fanatical believer in freedom of trade in alcoholic drinks,

1 Report of House of Commons Committee on Publie Breweries, 1818.

2 See the whole statement of C. Barelay, before the House of Commons Committee on the Sale of Beer, 1830. 


\section{LIQUOR LICENSING IN ENGLAND}

occupied a whole year over an elaborate investigation into the doings of the little coterie of Justices into whose hands the licensing work of the Tower Hamlets Division had been allowed to fall. ${ }^{1}$ Owners of East End house property, for which new licences had been refused, old established publicans, who had had their licences withdrawn, clergymen, and respectable inhabitants, aggrieved at the disorder of the multitude of low drink shops and "flash-houses" in their parishes, were encouraged to vent their several grievances before the committee. We need not attempt at this date to disentangle the unsavoury story in which Joseph Merceron, of Bethnal Green, who had a lively career as a corrupt parish "boss," played the leading part. That the half a dozen acting Justices of this particular division had given, withheld, and renewed licences for corrupt reasons was clearly proved. ${ }^{2}$ But in spite of one

1 A whole report, followed by 562 pages of evidence, is devoted to this subject (see First Report of the Committee on the State of the Police of the Metropolis, 1817).

2 Accusations of a more indefinite character, without attempt at verification, were loosely made against the other divisions of the Middlesex bench. A glimpse of similar licensing partiality in 1791 among some of the magistrates of the Hammersmith Division of Middlesex may be gained from a Letter to Sir John Danvers, Bart., by William Hyde (1791). The general laxness of the Middlesex Justices in licensing is graphically pictured in Observations and Facts relative to Licenscd Alehouscs, etc., by a magistrate (Dr. P. Colquhoun), (1791). For the Surrey Justices at a later date, see $A$ Letter to the 
or two sensational instances of an improper refusal or withdrawal of a licence, the net result of all this corruption and favouritism had been, according to the reight of evidence, not an undue restriction but an undue multiplication of licensed houses, not a Puritanical regulation of the conduct of publicans but a notorious laxity. The scandalous failure of the Tower Hamlets bench was, in fact, not an argument against the policy of 1787 , but an instance of the results of not adopting it. The House of Commons Committee, biassed by its free trade proclivities, and concerned only about the metropolis, did not attempt to examine the policy of restriction and regulation quietly persisted in by the county and borough benches up and down the country.

The outcome of this one-sided investigation was a report which, in effect, pronounced against the control of the liquor traffic by the Justices of the Peace. The essential feature of the licensing system, on which Parliament had, since 1743, relied, was the genuine exercise of the free discretion of the Justices in regard to their threefold power of selection, power of withdrawal, and power of imposing conditions. It was in the Lord-Lieutenant of the County of Surrey on the Miseonduct of the Licensing Magistrates and the eonsequent Degradation of the Magistracy, by Thomas Edwards, LL.D. (1825), reviewed in Edinburgh Review, September 1826. 


\section{LIQUOR LICENSING IN ENGLAND}

exercise of that discretion that the provincial Justices had, from 1786-87 onward, effected the remarkable changes-as most of them thought, the important reformis-implied in the reduction of the number of licensed houses, the insistence on suitable position and adequate accommodation, the prohibition of mere dram-shops, complete or partial Sunday elosing, a nine or ten o'clock closing on week days, and the suppression of brutal amusements and other disorder. We cannot discover that any member of the House of Commons Committee of 1816-17 had ever heard of the remarkable movement for the Reformation of Manners in $1786-87$, still less inquired into the circumstances and results of the drastic withdrawal of licences which then took place. It is an amazing instance of the ignorance with which English official business was at that time transacted, that from beginning to end of the voluminous proceedings of 1816-17 there is no mention of the striking upheaval which had taken place only thirty years previously. Under the influence of the contemporary theories at Westminster, the Committee took the view, dead in the teeth of a long series of decisions of the Courts of Justice, that the functions of the Justices in licensing were, and ought to be, confined to a merely ministerial 
execution of statutory provisions. In granting new licences, their duty was almost, if not entirely, confined to seeing that the applicant was a responsible person of good character. Though the Report does not expressly declare for complete freedom of trade, the Committee nowhere deprecate the granting of additional licences, and specifically "advise that licences should be granted to new houses . . . in those districts in which the monopoly is at present complete," so that the trade may be taken out of the few hands which, in some districts, have entirely engrossed it. In fact, they "strongly implore the different magistrates of the country to lend their aid to break down a confederacy which is so injurious to the interests of the poor and middling orders of the community."

The second part of the Justices' licensing power - that of withdrawal - is entirely condemned. "Your Committee think it by no means clear that the legislature ever contemplated that magistrates would assume the power of considering old licensed houses as new ones; or that . . . they should be able to deprive by their sole will and pleasure persons of their property, to which long enjoyment had given them a right, and upon which their existence and that of their families depended." They 
emphatically recommend "that no established victualler be deprived of his licence under any pretence whatever without a trial by jury," for some statutory crime.

The third power-that of imposing conditions - stands or falls with the discretional power of withdrawal, and is thus implicitly condemned by the Committee. The necessity of imposing conditions as to disorderly games, or hours of closing, or Sunday observance, or all the thousand and one details of conduct that from time to time arise, is not so much as mentioned. The Committee insist that the publican shall be as free as the butcher and the baker to do anything which Parliament has not specifically forbidden. They go out of their way to uphold "the long-undisputed and exercised right enjoyed by the victuallers to conduct their houses, and to sell ale, beer, wine, and spirits, in the manner and after the mode as suited best to the character of their respective customers." I

1 Report of House of Commons Committee upon the Police of the Metropolis, 1817. The remarkable exemption from all regulation of the sale of beer at fairs may here be noted. It had apparently long heen eustomary for the needs of the concourse of people at a fair to be met by many persons opening their houses for the sale of beer for the oceasion only. This right of any one to brew and sell at fair time, withont a licence, was preserved by 5 and 6 Edward VI. c. 25 (1552), and was continued by all suceessive licensing Acts until 1874. This led to an orgy of drunkenness ant disorder at every fair. $\Lambda$ writer in 1787 appeals in vain for "some regulation 


\section{The publication in 1817 of this report, with its two volumes of evidence about the brewers'}

and restriction of the bush-houses as they were called, viz. temporary alehouses where vice in all her forms is permitted to revel uncontrolled. A number of abandoned females are entertained in these houses, and suffered to molest every person who passes them, and to seduce the unwary in the face of day. Villains of all descriptions find in them an asylum, and too often form conncetions to break open houses and commit other atrocious depredations on society" (Bristol Journal, 25th August 1787). These "bush-houses," as they were called, were frequently complained of. Thus, of Barnstaple (Devon) in 1830 , we read that "at fair times the right to sell strong drink irrespective of Justices and excise was claimed and fully exereised. The person who wished to sell liquor during the three days of the Fair simply stuck a bush in front of his louse, and he thereby beeame a publiean for the time" (Gardiner's Barnstaple, 1. 57). As late as 1849, at the great annual fairs at Fazeley and Rugeley (Staffs), they are reported to be "an intolerable nuisance . . . the constabulary have no power to enter . . . or to punish the occupiers for selling beer all night, and for permitting drunkenness or immorality . . . there are constant complaints about it" (Report of House of Commons Committee on the Sale of Beer, 1850, p. 34). ". . . After the five or six hours of the cattle fair, their houses are . . the peculiar rendezrous of all the thieves and prostitutes that attend from Birmingham the three days' fair " (ilid. pp. 134-135). In the first quarter of the nineteenth eentury the exemption, which in strict law was confined to preseriptive or chartered fairs, was commonly taken to apply to all "wakes" and village revels. Thus it was reported in 1817 from Shropshire that "during a certain week in every year there takes place in most parishes in this county a kind of rural revelling generally known by the name of wake. . . On thesc oceasions it is not unusual (in villages where there is no public-house) for unlicensed persons to brew a certain quantity of beer to be sold during the wake, at all hours, ... . which sale is commonly announced to the exeise officer of the distriet, who gives an apparent sanetion to it by receiving the customary duties for the liquor brewer with that design." On certain Justices trying to suppress this custom in 1815-16, the Commissioners of Excise insisted on its continuance, and obtained statutory powers (56 George III. c. $104 \mathrm{sec}$. 105) to give temporary jermits to sell beer without the Justices' licence (Report of House of 


\section{LIQUOR LICENSING IN ENGLAND}

monopoly and the Tower Hamlets Justices, marks a turning-point in the history of licensing practice. The tales told to the Committee of the corrupt and arbitrary conduct of the Tower Hamlets Justices were adapted or varied to suit the local circumstances by every Radical newspaper, and repeated by every Radical member in the House of Commons, whilst the recommendations of the Committee as to what the Justices' licensing powers ought to be, were boldly assumed to be the actual state of the law. No one writes to describe the actual practice of the Justices, or mentions their inquiry of the Vestries as to how many publichouses are required. $\mathrm{We}$ find absolutely no mention of the policy of 1786-87, or of its dramatic and even wholesale withdrawals of licences. The whole episode seems to have been forgotten by friends and foes alike. The letters to the newspapers do not, as in 1787, complain of the prevalence of disorderly drinking. What the correspondents are concerned about is the fact that a licensed victualler,

Commons Conmittee on the State of the Police of the Metrololis, $1817, \mathrm{pp} .218-220)$. It is astonishing that not until 1874 was this immemorial abuse put a stoy to. The Licensing Act of that year ( 37 and 38 Vict. c. 49 see. 18) abolished the ancient privilege of free sale, nade a licence necessary, and cnabled the Justices to grant an "occasional" licence to meet the temporary need (see The Licensing Acts, by J. Pater'son, 13th edition, 1900, 1. 202). 
alone among tradesmen, is "subjected to the ruinous effects of petty tyranny .. . he is punished without a hearing and without knowing his offence, on a secret information. . . . Thus after a man has embarked his whole property in this line of life he is frequently, on the mere fiat of a licensing magistrate, robbed of his only means of subsistence. In a case laid before the Police Committee, a person paid $£ 1000$ for the lease of a house, the licence was taken from it without any assigned or apparent reason, and he was ruined." 1

We see the effect on the minds of the Justices themselves. One bench after another begins

1 Manchester Observer, 14th February 1818. In the Tory Quarterly Review for April 1818 we see what may perhaps be called the last stand of old-fashioned folk for the old idea. In discussing "the means of improving the people," the multiplicity of unnecessary licensed houses is alluded to as an evil. "To advise any sudden reduction of their number would be absurd . . . but no new honse shonld be licensed without clear proof that it would be useful to the neighbonrhood, which it could only be where a new village was rising, or where there was a rapid increase of inhabitants from some local eauses. That a gentleman's servant wanted an establishment or that a brewer found it advantageous to have another taproom opened for the consumption of his beer, anght not to be considered sufficient causes for adding to what are already far too numerons. With regard to the unnecessary number of houses that are already open, the licence should not be renewed when the present oceupier removes or dies; one generation would then produce the desired reduction. And in every instance where riot and drunkemess were suffered, or the doors kept open till an improper hour of the night, the licence should uniformly be taken away. Were the magistrates and parish oflicers strictly to enforce these latter. . . they wonld soon perceive the good effect in the amended morals of the parish." 


\section{LIQUOR LICENSING IN ENGLAND}

to weaken in its adhesion to the policy of 1787 . All idea of regulation is given up. The very power to make conditions is assumed to be nonexistent. ${ }^{1} \quad$ As regards increasing the number of publicans the change of policy was, however, neither universal nor simultaneous. Throughout the greater part of rural England, right down to 1830 , it continued to be taken for granted that each parish should have its one publichouse just as it had its one church." 'The oldfashioned village inn, with its parlour and taproom, "kept by a regular steady man . . . of some property," " was resorted to by men of all classes, the labourers thus drinking, as it. was said, "under the eye of parlour company." \&

1 Thus, in spite of the "articles" of 1618 , of the "conditions" mentioned in Burn's Justice of the Pcece, and of the innumerable precedents of Justices in every county, when the Surrey maristrates in 1828 wished to make licensed houses, which were also places of entertainment, like Vauxhall Gardens, close at some definite hour, they considered that they had no power to enforce this or any other requirement as a condition of granting the licence. "It is," they said, "a lieence either to be given alssolutely, or denied absolutely; it is not in our power to impose any conditions" (Report of Select Committee on the Police of the Metropolis, 1828, p. 136).

2 Thus it appears that, prior to 1830, 22 parishes in Somerset had exactly 22 licensed houses; 12 parishes in Berks and Oxon had just ahout 12 licensed houses; and of one parish in Sussex we are expressly told that no second public-honse was allowed (Report of House of Conmons Committee on the Sale of Beer, 1833, pl. 145, 160, 192).

3 Ibial. 1. 160.

${ }^{4}$ Report of House of Commons Committee on Drunkenness, 1834, p. 33 . 
In many districts the Justices continued to recognise the right of the "principal inhabitants" to veto the establishment of eren one publichouse where none had previously existed. ${ }^{1}$. In other divisions the Justices, thinking the publichouses too numerous, withdrew licences at their discretion. ${ }^{2}$ Nor were the magistrates in the municipal corporations more free-handed than the county Justices. The reports of the Municipal Corporation Commissioners show that where the population was stationary, it was customary for the old-established public-houses in the small boroughs to remain, decade after decade, undisturbed, the number of licences being neither increased nor diminished. ${ }^{3}$ In

1 Thus in Devonshire we hear of one village in whieh, through local influence, the Justices for twenty years refused to grant any licence; whilst in Hampshire a leading hrewer bitterly complained that there were many parishes withont any publie-house; the "conntry gentlemen and clergymen," he said, "were very averse to having beer-shops near their residenees, not considering the advantages the cousumers of beer derived from them " (Report of House of Commons Committee on the Sale of Beer, 1833, H. 52, 199, 200). There were evidently many small rural parishes in which there was no licensed house of any sort. In the remote villages near Falmonth (Cornwall) it was said of the last decade of the eighteenth century "there were then neither beer-shops nor grin-shops anywhere within reach" (Autobiography of James Silk Buckingham (1855), vol. i. p. 21).

${ }^{2}$ So in the Aylesbury division of Bucks (Report of Honse of Commons Committee on the Sale of Beer, 1830, 1. 79 ; and at Yoxall (Staffs), where 14 had been reducerl to 2 (ibill. 1833, p. 171).

${ }^{3}$ In nearly every case in which the Municipal Corporation Com. missioners give farticulars in 1883 as to the increase or decrease of 


\section{LIQUOR LICENSING IN ENGLAND}

some of the larger towns, as we have seen, licences had been multiplied in the old lax times, and the Justices were in the first quarter of the nineteenth century still trying to reduce their numbers. ${ }^{1}$

licensed victuallers, they record a restrictive policy on the part of the borough magistrates. Thus at Reading (Berks) the bench had resolved to grant no now licences; at Bodmin (Cornwall) only two had been granted during twenty years; at Falmouth (Cornwall), in spite of frequent applications, only one had been granted during ten or twelve years, and at Penryn none; at West Looe (Cornwall) the number lrad not been increased for thirty years; at Plymouth (Devon) the magistrates had for years tried to reduce the number, refusing eight applications in a batch; at Chichester (Sussex) no new licences had been granted for over seventeen years; at Portsmouth (Hants) a new licence was scarcely ever granted, and 14 out of 242 had not been renewed; at Rochester (lient) the number had been reduced from 61 in 1811 to 58 in 1833 ; at Dover (Kent) there had been only one new licence since 1824; at Faversham (Kent) none for many year's; at Doncaster (Yorks) the number had remained stationary for five years; at Beverley (Yorks) it had been reduced by one; at Hull (Yorks) the number had been reduced from 223 to 211; at Lancaster (Lancs) there had been no new licence since 1823; at Leeds (Yorks) a few were granted each year, but the magistrates strove to keep them down, refusing nineteen of the applications; at Ripon (Yorks) the number had been reduced from 49 to 39 in ten years. At Searborough (Yorks) there had been no increase for seven years, until shortly before, when three had been granted. At Maidstone (Kent) six new licences had been granted since 1825. (See the various volumes of the Appendix to the First Report of the Mnnicipal Corporation Commission, 1835.) This undisturbed mono. poly had its bad side. Wayfaring artisans and pedestrians of all sorts often found difliculty in obtaining accommodation. The well-to-do publicans in the small towns beeame "so higl and saucy," and demurred to receiving travellers "unless they come by coach, or have a horse or gig" (Report of House of Commons Cominittee on Sale of Beer, 1833, 1. 171). On the other hand, sueh publie-houscs kept themselves free from any kind of disorder.

1 So at Liverpool in 1821, where it was said that "the vast number 
Presently we see the wave of opinion against the brewers' monopoly and in favour of freedom of trade overtaking some of the county benches. In 1825 , as if with the object of encouraging the smaller alehouses to sell spirits, Parliament reduced the publicans' spirit licence, hitherto costing at least five guineas a year, to only two guineas a year for houses under $£ 10$ value. This led to a large proportion of the alehouses both in town and country to become also places for the sale of spirits. There was also an increase in the number of alehouses. In one county after another, as in Buckinghamshire about 1826, "the liberal spirit of the age" ${ }^{1}$ leads to new public-houses being licensed, even where population and trade were declining. The Surrey magistrates actually petitioned Parliament in 1826 " to authorise the excise to grant a beer

of public-houses in this town has long been a subject of remark with strangers and of regret with residents, and never was the licensing system a topic of disenssion here as since the last licensing sessions, when the magistrates, anxious to reduce the number of public-honses and dram-shops, refused to renew the licences of many whose misconduct had incurred the penalties of the law, or whose entire pursuit of the drant-selling trade appeared to be injurions to the morals of the community. The consequences of this refusal have, in many cases, been extremely salutary, but in others highly iujurious to respectable and industrious individnals," owing, as the writer explains, to the Justices' failure to discriminate (Liverpool Mercury, 7 th Deccmber 1821).

I Report of House of Commons Colmmittee on the Sale of Bcer, 1830, l. 76. 
licence after the manner in which a tea licence was granted." 1 Other benches virtually adopted this policy of freedom of their owl accord. Thus, in the Morley division of Devon, the magistrates, after for years pursuing a restrictive policy, came to the conclusion that the effect of this was merely to "raise the price of beer beyond its natural level," and decided, about 1827-28, "to grant a licence to every man of respectable character who applied for it; in fact, they opened the trade in public-houses." The 60 or 70 publichouses which had for years supplied their 33,000 population were suddenly increased to 110 . "The trade in beer," said one of the acting Justices, "should be quite as open as the trades of the butchers and bakers." " In part of Cornwall we are told licences had, about 1827-30, become perfectly free; they "are granted to any one who chooses to ask for them." ${ }^{3}$ The same influences were at work in the northern counties. In Durham, where a period of laxity had been, after 1787 , followed by one of restriction, and where, during the first quarter of the nineteenth century, "the habit" of the magis-

${ }^{1}$ House of Commons, 13th April 1826 (Plain Papers relating to the Exise, by John Owens (Linlithgow, 1878), 11. 87).

2 Reprort of House of Commons Committee on the Sale of Beer, $1838,117.57-58$.

${ }^{3}$ Ibid. 1830, Y. 89. 
trates had been "to impose a considerable restraint upon the granting of new licences . . . the feeling ... gave way to the general principles of free trade. It was thought that the throwing licences more freely open would be the means at least of an improvement of the article itself, and restraining the monopoly of brewers over public-houses." The Justices forgot, said a repentant member of this very bench, giving evidence in 1834 as to the disastrous increase in drunkenness, that spirits were not the "same as groceries." Licences were accordingly multiplied freely. "You would scarcely now be able," said this witness, "to put your foot down without meeting with a public-house; they are found in all directions." In Leeds, too, it was stated in 1833 that "the number of . . licensed victuallers has increased. We probably were too tight at one time: we kept down the number, and we found that it only had the effect of increasing the value of the premises. . . Every year we have increased the number." 2 Partial and gradual as was this change of policy among county benches, we see it reflected unmistakably in the statistics. The total number of ale-

1 Report of House of Commons Committee on Drunkenness, 1834 , p. 311.

${ }^{2}$ Report of House of Commons Committee on the Sale of Beer, 1833, p. 109. 
house licences increased from 47,933 in 1824 to 51,482 in 1830, and the number of these enjoying also a spirit licence bounded up from 37,196 in 1824 to 42,599 in 1826 and 45,675 in $1830 .^{1}$

Meanwhile the agitation in favour of freedom of trade in alcoholic liquors was steadily growing in the House of Commons. Those who take the trouble to read the parliamentary proceedings from 1818 to 1830 become aware, alongside of the more sensational episodes of the time, of a persistent clamour by a small knot of people against the Justices' control of the liquor traffic. This took many forms. Pathetic petitions from persons distressed at the withdrawal of their licences were laid before the House, and these hard cases were dilated on by Ministers as well as by private members. Owners of house property and newly established brewers found Free Traders in the lobby ready to hear their tales of new licences unwarrantably refused. Oldestablished publicans were sympathetically listened to when they complained of being ordered to close their houses on Sundays or at fixed hours at night, or to provide a parlour, a fire, and a newspaper, whilst disorderly coffee-

1 See $\Lambda$ ppendices to First Report of Commissioners of Inland Revenue, 1857. 
houses and "night-cookshops" were free to do as they liked. There were rumour's of political favouritism in the licensing work of the aldermen of the close municipal corporations; whilst as to the metropolis it was continuously asserted that all the respectable magistrates withdrew from the Middlesex licensing sessions, so despicable had become the social status and personal conduct of the acting Justices. Even the county magnates were charged with a selfish refusal to allow alehouses in their villages, because such places gave them trouble as haunts of poachers and Radicals. ${ }^{1}$ More influential was probably the alarm felt at a falling off in the consumption of beer which not only threatened the interests of the revenue, but was felt to be a serious loss to the producers of barley and hops. ${ }^{2}$ The old prejudice against the consumption of ardent

1 See for all this the various petitions, bills, and debates recorded in Hansard for the period, e.y. vol. xxxix., 28th January 1819; vol. xl., 5th and 21st May 1819; 6th, 14th, 24th, and 29th May, and 18th July 1822; 28th February 1823; 13th and 21st April 1826; 7 th and 14th March, and 21st May 1828.

2 The revenue statistics indicate that "the production of 1722 , when beer was the beverage of the people at every meal, gave a barrel of beer per hear; but in 1830 the rate of consumption had fallen to half a barrel per head. In the meantime the consumption of tea had increased from 1 ounce per liead to 36 ounces, and spirits from half a gallon to six-sevenths of a gallon per head" (Twenty-Eighth Report of Commissioners of Inland Revenue (1885), p. 20, quoting that of the Commissioners of Excise for 1833). 
spirits was revived. Beer, on the other hand, was still universally regarded as a necessary of life. Hence the more practical of the reformers who wanted to abolish the licensing system altogether confined their immediate proposal to "free trade in beer." Measures in 1823 and 1824 encouraged the manufacture of a cheaper beer, and permitted the "home brewer" to retail his product for consumption off the premises without a Justices' licence. ${ }^{1}$ These Acts failed to shake the increased hold of the great brewing firms. "Intermediate beer," as the cheaper product was called, did not become popular, and the unregulated "retail brewers" obtained only an insignificant fraction of the trade. It so happened that both the great political parties were inclined, though for different reasons, to favour what Sydney Smith called "Free Trade in ale and alehouses." To the Radicals it seemed a step towards the universal freedom of every one to do what he liked with his owu. ${ }^{2}$

14 George IV. e. 51 (1823), and 5 George IV. e. 54 (1824), the latter containing also important modifications of the tax on spirit licences (see History of Tuxation and Tuxes, by S. Dowell (1888), vol. iv.; the Beer Manuel (1892), and the Spirit Manual, Historical and Techical, both by Joseph Scarisbrick).

"Sydney Smith, writing on 26th December 1826 to Edward Davenport who was entering Parliament, said, "Arlvoeate free trade in ale and alehouses" (Memoir of sydney s'mith, by Lady Holland, vol. ii. p. 271). It is wrongly dated in Temperance in the Tricturiun Ave, hy Dr. Dawson Burns (1897), p. 173. In the Honse of Commons, 
The Tories were captivated by the idea of encouraging the growth of hops and barley to the benefit of the agricultural interest, and of enabling the sale of beer to displace that of spirits or wine to the advantage, it was assumed, of the public health. Presently the movement obtained the great aid of Huskisson, who was then, step by step, liberating the trade of the country from fiscal fetter's. Against all these forces there seems to have been practically no opposition. No one at this time asserted the need for a temperance policy. Whatever may have been left of the movement for the reformation of manners had, at any rate, become completely ineffective in Parliament, in which the Radicals were, as Daniel O'Connell observed,

Slaney, one of the leading social reformers among the Radicals, emphatically declared, in connection with Esteourt's Licensing Bill, that "he would not put into the hands of auy individual a power affecting the price of what in England was eonsidered the second recessary of life: such a power was eontrary to the principles of Free Trade; and he thought the general principle that the demand for goods ought to regulate the number of vendors should be applied to this trade as well as any other" (Hansard, 21st May 1828). The attitude of the most philanthropic and enlightened Radicals may be gathered also from an amazing article in the Edinburyh Review for September 1826 , in which beer-drinking by the labourers is justified and glorified, the liceusing Justices are ridiculed and denounced for attempting to regulate the number or conduct of public-houses, and the utmost freedom of competition in the liquor traftic is demanded. This article, though not catalogued by Lady Holland as Syduey Smitl's, is evidently by him. In July 1826 he asks Jeffrey for permission to do it (Memoir, vol. ii. p. 266). 


\section{LIQUOR LICENSING IN ENGLAND}

averse from anything like "this perpetual meddling with the habits of the poor." 1 So far as excessive drinking led to disorder and crime, the answer of the Tory Government of that day was not any development of the restrictive and regulative policy of the licensing Justices, but the establishment of a highly disciplined preventive police. Even the "vested interests" which were threatened by Free Trade in beer were unable to offer a coherent opposition. The licensed victuallers had given themselves away to the Free Trade party by their persistent agitation against being regulated by the Justices, and when they pleaded the "sanctity of property," arising out of the monopoly which that very regulation by the Justices had created, they were simply not listened to. The brewers had a divided mind. They naturally desired the reduction of the taxation on beer, and the abolition of the existing discrimination in favour of the home-brewed product. As brewers, they had all to gain by the throwing open of the retail trade. On the other hand, as owners of publichouse property, they shared with the licensed victuallers themselves an alarm lest the selling value of their houses should be diminished by the abolition of their monopoly. After various

I Hansard, 24th August 18:1. 
ineffectual attempts by private members, ${ }^{1}$ Goulburn, the Chancellor of the Exchequer in the Duke of Wellington's Ministry, determined in 1830 , as part of the Budget, both to remove the tax on beer and cider, and to throw the retail sale completely open. ${ }^{2}$ The brewers thereupon publicly withdrew all opposition. The country gentlemen, appeased by the prospect of an increased demand for barley and hops, seem not to have realised that the whole control of the rural alehouse was about to be taken from them.

1 Iention may here be made of a meritorious Act of 1828 got through by Estcourt, which codified the law as to the Justices' procedure in licensing, repealed a bewildering mass of old statutes, and in 1903 still forms the basis of the law (9 George IV. c. 61). His attempt to increase the regulative and restrictive powers of the Justices was successfully opposed by the House of Commons, Sir J. C. Hobhouse declaring that the magistrates were in general already "too much disinclined to grant licences" (see Hansard, 14th and 21st May 1828). The Justices' powers of superrision were even limited in such matters as their right to order licensed premises to be searched on mere suspicion of offence (Rejort of House of Commons Conmittee on the Sale of Beer, 1833, p. 101), and their general authority was greatly weakenerl by abolishing the requirement of certificates of character, even for new licences, and by permitting an appeal from the Brewster Sessions to Quarter Sessions. 'The sale of beer for consumption off' the premises was made free withont licence. The power of two Justices peremptorily to "reject and put away"that is, suppress-a common alehouse, under 11 Henry VII. c. 2. (1495) was explicitly repealed.

${ }^{2}$ Goulburn declared, as one of his reasons, "that the consump. tion of spirits had doubled in twenty years (1807-27), and while the beer and ale licences had fallen off, the spirit licences had increased by 11,000" (Beer. Lfanual, by Jose ph Scarisbrick (Wolverhampton, 1892), 1. 19). 


\section{LIQUOR LICENSING IN ENGLAND}

A perfunctory select committee, appointed to endorse a foregone conclusion, gave formal audience to the exaggerated estimates of ruin apprehended by existing licence-holders. ${ }^{1}$ But no attempt was made to inquire what would be the effect of the measure on drunkenness and disorder. No one recalled the experience of Free Trade in liquor between 1689 and 1729 ; or that of the indiscriminate granting of licences and neglect of regulation between 1753 and 1787 . No evidence was sought or tendered as to the relative social condition of districts in which licences had been restricted and publicans regulated, compared with those in which licences had been granted practically without limit or conditions. The decision to allow Free Trade in beer, momentous, as we shall see, in its consequences, may indeed be cited as the leading case of legislation based on abstract theory-on axioms deduced from first principles - without investigation of previous experiments, without inquiry into the existing facts, and even without any clear conception of the state of society which it was desired to bring about. The proposals of the Government were adopted in their entirety.

1 Reprort of House of Commons Committee on the Laws and Regulations restrieting the Sale of Beer by retail, 1830 ; see also $A$ Few Words on the Licensing System and the Proposed Tnlimited Increase of Public-Houses (18:30). 
The second reading of the Beer Bill was carried by the overwhelming majority of 245 to $29 .{ }^{1}$ Attempts to restrict the new beer-shops to sales for consumption off the premises only were defeated by large majorities in both houses. Within a few weeks from the introduction of the measure it had become law that, from aud after the ensuing autumn, any person whose name was on the rate-book might open his house as a beer-shop free from any Justices' licence or control, merely on payment of two guineas to the local office of excise. ${ }^{2}$

So instantaneous and dramatic a transformation as occurred in October 1830 has seldom

1 Hansard, 4th May 1830 (vol. xxy.).

211 George IV. and 1 William IV. c. 64 (1830); Hansarr, vol. xxv. 1830, pp. 580, 1104, ete.; History of England, by Spencer Walpole (1879), vol. ii. p1). 545-546; History of England during the Thirty Years' Peace, by Harriet Martinean (1849), vol. i. ch. x. p. 545. It has been said, we know not on what authority, "that the Duke of Wellington eonsidered that the passing of this Bill was a greater achievement than any of his military victories" (The Temperance Movement, by P. T. Winskill (1892), rol. i. 1. 18). So far was the Free Trade policy carried by the executive government that retailers of table-beer only, eharging not more than $1 \frac{1}{2} \mathrm{~d}$. per quart, whether for consumption on or off the premises, were exempted even from taking out an excise licence or other formality (see Treasury letter of 9 th November 1830 interpreting 42 George III. c. 38, see. 18 (1802), in the sense most favourable to freedom). Sueh "swankey shops," as they were called, remained for a whole generation absolutely unenumerated, untaxed, mlicensed, and unrestricted (Report of Select Committee on the Operation of the Acts for the Sale of Beer, 1850, pp. 44, 54, 75; History of Taxation and Taxes, by S. Dowell (1888), vol. iv. p. 97). 


\section{LIQUOR LICENSING IN ENGLAND}

been effected by any Act of Parliament. The very day on which the statute came into operation, a perfect swarm of what, for some inexplicable reason, were called "Tom and Jerry shops" or "tiddlywinks," were opened in every town and village. The excise offices were besieged by householders eager to pay the two guimeas by which they acquired the privilege of retailing beer. In Liverpool alone there opened more than fifty additional beer-shops every day for several weeks. Within less than six months no fewer than 24,342 new beer-sellers had paid the excise fee, and the number still continued to grow with great rapidity. ${ }^{1}$ It is impossible to describe the orgies that ensued. "The new Becr Bill," wrote Sydney Smith only a fortnight after it had come into force, "has begun its operations. Everybody is drunk. Those who are not singing are sprawling. The sovereign people are in a beastly state." ${ }^{2}$ The

1 "Within nineteen days from 10th October, as many as 800 licences were taken out under the Act in Liverpool alone, and by the end of the year the total number of licenees granted in England and Wales rose to 24,342 " (The Temperance Movement, by P. T. Winskill, 1892 , vol. i. p. 18). The number rose to 30,978 in $1831,33,515$ in 1832 , and to no fewer than 45,717 in 1838. See p. 41 of Thirteenth Report of Commissioners of Inland Reveme, 1870; History of Taxution and Tuxes, by S. Dowell, 1888, vol. iv. 1p. 95-96.

2 Sydney Smith to John Murray, 24th October 1830, in Lady Holland's Memoir, vol. ii. p. 310. Only four years before, as previously mentioned, he had been advocating lree Trarle in ale and in alehouses. 
new beer-shops were naturally kept by all sorts and conditions of men-persons who had been refused public-house licences on account of bad character, "petty tradesmen who would rather get their bread by any other way than by hard labour," " poor widows set up in an easy business by the charity of their neighbours, or even by gifts from the poor rate, unemployed labourers whose cottages happened to be rated, and all the nondescript class of those who combined a little poaching and gambling with the occasional receipt of stolen property. Many of these persons were mere pawns in the hands of those who supplied the beer. To take advantage of Free Trade, a new type of brewer sprang up, whose agents travelled from village to village to persuade all and sundry persons to start selling beer, even in the smallest way, advancing the two guineas for the excise fee and supplying casks on credit: One firm boasted in 1833 of having itself opened 200 such beer-shops in the town of Birmingham and the neighbourhood." In country villages, "where there was formerly only one public-house," the workman had " now to run the gauntlet through three or four beer-shops, in each of which are fellow-

$\therefore$ Report of the Conmittee on the Sale of Beer, 1833, 1. 7 .

2 Ibid. p. 170. 


\section{LIQUOR LICENSING IN ENGLAND}

labourers carousing who urge him to stay and drink with them." " The local veto exercised by the squire, the clergyman, and the principal inhabitants was ruthlessly broken down. One large brewer prided himself on having set up beer-shops throughout Hampshire in one hamlet after another, where, as he said, the selfish policy of the farmers had made the labourers "hardly know the taste of beer," a commodity which he intended should become to the rural population, "as it has to the inhabitants of towns, almost a necessary of life." 2 The situation and character of the new drink-shops were as harmful as their numbers. Hitherto the houses in which intoxicants had been allowed to be sold had been premises of a certain size and prominence of position, devoted exclusively to this trade, and situated in such a way as to be always under public supervision. Not only was beer now sold at every baker's and petty chandler's shop: regular drinking - places were opened in cellars and back premises in every alley in the town slums; in lonely cottages in the country bylanes; often, indeed, in mere sheds behind the village street, by the roadside, or in the remote recesses of a wood. It is easy to imagine, in

1 Report of House of Commons Committee on Drumkenness, 1834, 1. 31 .

2 Ibid. 1. 200 . 


\section{FREE TRADE}

the absence of any efficient police, the accompaniments of gambling, brutal amusements, and licentiousness, which the competition of beersellers for custom encouraged in such places. The regulations of Parliament as to hours of closing, etc., were simply set at naught. "Houses of this description," writes one observer in 1834, "sprung up in every corner of the land, by the roadside, in every city, town, and village . . have become the resort of individuals of depraved, abandoned, and desperate character," who are "encouraged in but too many cases by the loose principles of those who have adopted this line of trade." 1

It is hard to find a redeeming feature of this debauch." The optimistic prophecy that an increased consumption of beer would be accompanied by a permanent reduction in dramdrinking was completely falsified. For the first two years that the 30,000 new alehouses were plying the labourer's with beer, there was a slight check to the growing consumption of

1 Bristol Journal, 25th October 1834.

- Apart from the profit to the public revenue, and to the growers of barley and hops involved in the greater consumption of beer, the only thing that can be said in favour of the new beer-houses seems to be that they did multiply the facilities for lodging the travelling artisan or poor pedestrian, a kind of accommodation which had in some places been deficieut (see the experiences given in Banford's Early Days). 


\section{LIQUOR LICENSING IN ENGLAND}

spirits. ${ }^{1}$ But within a very short time this had again risen to a total never before reached. Nor are the reasons for this increase far to seek. The existing licensed victuallers naturally strove to develop the sale of the article which the beershops could not supply, with the result, as we are told in 1834, that " many of the old victualling houses where beer was principally consumed, and not spirits, have been turned into splendid gin-shops." 2 It was this new competition of the beer-shop, in fact, which led to the creation of the modern "gin-shop rising like a palace," which, in the words of a witness of 1834, "absorbs the wealth and the health and the life of the labouring class." 3 Contemporary observers described the transformation "A low dirty public-house with only one doorway" would be converted "into a splendid edifice, the front ornamented with pilasters supporting

1 The amount of British spirits charged to duty in England and Wales was $3,684,049$ gallons in $1825 ; 7,407,204$ in 1826 , on reduction of duty ; 7,759,687 in 1828 ; $7,732,101$ in $1830 ; 7,281,900$ in 1832 ; $7,644,301$ in $1834 ; 7,930,490$ in 1838 ; and $9,076,381$ in 1845 (seo A ppendix No. 19 in First Report of Commissioners of Inland Revenue, 1857).

2 Report of House of Commons Committee on Drunkenness, 1834, p. 115. "The beer-shops have tended to increase the number of dram. shops.... The publicans complain that they were compelled to adopt the system of opening a dram-shop . . . in order to make up for the deficiency in the sale of their beer" (ibid. 1. 53).

${ }^{3}$ Ibid. 1) 99. 
a handsome cornice and entablature and balustrade, and the whole elevation remarkably striking and handsome; the doorways were increased in number from one, and that a small one only three or four feet wide, to three, and each of those eight to ten feet wide; the floor was sunk so as to be level with the street; and the doors and windows glazed with very large single squares of plate glass, and the gasfittings of the most costly description; the whole excited the surprise of the neighbourhood. . . When this edifice was completed, notice was given by placards taken round the parish; a band of music was stationed in front... the street became almost impassable from the number of people collected; and when the doors were opened the rush was tremendous; it was instantly filled with customers and continued so till midnight. I naturally concluded . . . that this house had all the customers . . (but) we found all the other gin-palaces were equally crowded as before; they had all lowered their prices to compete with this new shop, and attracted a large number of customers; each gin-shop, in fact, was as full as it was possible to be of customers." 1 Moreover, the establish-

1 Reprort of House of Commons Committee ou Drunkeuness, 1834, p. 274. It became increasingly the custom for the licensed victuallers 


\section{LIQUOR LICENSING IN ENGLAND}

ment of new beer-shops was a direct cause of an increase in the number of fully licensed publichouses. It became the policy of some licensing benches to press and persuade the beer-shop keepers to take out a licence for the sale of spirits in order to get some hold over them, and so obtain a more effective guarantee of orderly conduct. ${ }^{1}$ Even the regulations which the Justices had made for the public-houses had to be relaxed in face of the competition of the unregulated beer-house. Up and down the country, as we have described, the Justices had striven to enforce some measure of Sunday closing. Parliament had forbidden the beershops to be open after ten o'clock at night or before five in the morning, but had made no special law as to Sunday hours. The consequence was that where the Justices had insisted on the public-houses being entirely closed on to employ musicians and singers. "Nany of the pullicans," we are told in 1834, "have organs in their houses"; and in Nanchester, declared the Boroughreeve, they even played jisalm tunes on Sunday evenings, "as an inclucement for the parties to go and spend their money there rather than go to the beer-shops" (ibid.p. 53). No licence or permission was then required for public music or dancing except (hy 25 George II. c. 2) within twenty miles of London, and in a few towns ly their Local Acts.

1 Thus, both at Dartmouth and at Torrington (Devon) the magistrates, between 1830 and 1833 , deliberately granted new licences in order to obviate the establishment of mere beer-shops not under their control (First Report of Municipal Corporation Commissioners, Appendix, vol. i. ply. 475 and 671$)$. 
Sunday, or closed until after divine service, they were practically compelled to relax these rules and allow the licensed vietuallers, like the beer-shops, to be open all Sunday, provided that they respected the general prohibition of drinking during the hours of divine service. ${ }^{1}$

By the time the new Parliament met, in Mareh 1831, the first results of Free Trade in beer had eaused a perfeet panic of alarm among those who were responsible for the peace and good order of the countryside. The winter had, in the south of England, been one of almost constant uproar and sullen rebellion, during which rieks had been burnt and machinery destroyed. ${ }^{2}$ The new beer-houses, exempt from magisterial control, were the places of meeting of the disaffected labourers, and thus, it was said, the centres where rebellion was fomented and plans of incendiarism were coneocted. Resolutions poured in from Quarter Sessions, expatiating on the evils which the Act of 1830 had brought on peaceful villages. ${ }^{3}$ The bishops

1 See the case of Stockport (Cheshire) in Report of House of Commons Committee on the Sile of Beer, 1833, 1. 238.

$2 \Lambda$ description of the riots and rick burnings in Dorset in 1830 is given in The Journal of Mary Framplon, edited by H. G. Mundy, 1885 , р. $361-368$.

3 The following is but a sample of innumerable contemporary resolutions :- "That it is the opinion of the magistrates here present that, in villarges and conntry places, the provisions of the Act 


\section{LIQUOR LICENSING IN ENGLAND}

in the House of Lords foreibly urged on the new Whig Ministry the "alarming increase of immorality, pauperism, and vice among the lower orders arising from the great number of beer-shops." " "Every third or fourth house in some of the country towns," said the Bishop of Bath, "had become a beer-shop." 2

Petitions from Justices and clergymen, churchwardens and overseers, vividly described the horrors of the new trade-the tippling, the late hours, the noise and disorder, the indiscriminate intercourse of young and old and both sexes, the music and dancing, the gambling, the receiving of stolen goods or the proceeds of poaching, the filling of the prisons and the raising of the poor rates - and beseeched the House of Commons for an immediate repeal of the Act. ${ }^{3}$

(11 George IV. and 1 William IV. c. 51) have been productive of great inconvenience ant injury both to the peace and good order and morals of the people. That in towns similar bal consequences do not appear to have arisen, but that, on the whole, the multiplication of houses for drinking beer on the premises has been productive of serious evil" (MS. Minutes, Quarter Sessions, Wiltshire, 5th $\Lambda_{\text {pril 1831). }}$

1 Hansard, 24th March 1831.

2 Ibid. 23rd June 1831.

3 Testimony to similar effect was constantly repeated all over the country. The chairman of the Cheshire Quarter Sessions in 1833, in eharging the grand jury, pointed ont " that the eastle of Chester contained a greater number of persons for trial at the ensuing assizes than was ever known in the memory of man." He unhesitatingly attributed this "to the general demoralisation arising from . . . the pernicious effects of the Beer Bill. . . . He had had repeated com. plaints against beer-honse-keepers for allowing gambling in their 
Brougham, Melbourne, and Althorp all admitted the weight of evidence against the new system, but they suggested that the county magistrates and clergymen were exaggerating; that the evils were local only, not prevailing to the same extent in the northern towns; that matters would right themselves in due time; and that the Government were not "prepared to abandon the principle of the measure, and to place again under any local authorities the choice of the places in which there should be houses for the sale of beer." ${ }^{2}$ No amount of evidence as to the harm which the new beer-houses were doingcould shake the determination of the doctrinaires. It was in vain that nearly all the Whig Government's own Commissioners-notably those who investigated the Old Poor Law and the Municipal Corporations-brought back to London the strongest testimony against the new beer-shops. It was useless for the first House of Commons Committee on Drunkenness in 1834 to report in the strongest terms against "the increased number and force of the temptations... by the additional establishment of places at which houses; at such places farm-servants were plundered of their earnings, and offences were in consequence increased. . . . So long as the beer-shops were permitted to remain, he feared they (the Justices) would be impeded in their efforts to do anything for the benefit of the county" (Chester Courant, 31st December 1833).

1 Lord Althory' (see Hansard, 30th June 1831). 
intoxicating drinks are sold," amounting to " not less than one such place to every twenty families throughout the United Kingdom." : Practically nothing was done by the Whig Ministry to alter the law. Our investigation into the licensing system thus ends, as it began, with the free sale of one kind of intoxicant. The student of contemporary accounts of the nineteenth century Free Trade in beer will find it easy to parallel, almost line for line and word for word, the contemporary descriptions of the previous experiment of the eighteenth century Free Trade in gin.

1 Rejort of Honse of Commons Committee on Drunkenness, 1834, p. iii. 


\section{CHAPTER V}

LEGISLATIVE REPENTANCE

We are not in a position at present to carry beyond the passage of the Beer Act of 1830 our detailed description of the development of the English licensing system. When we have completed the first volumes of our History of Local Government, bringing the story down to the reforms of 1832-35, we hope to be able to continue our investigations down to the end of the nimeteenth century. In due course, therefore, we anticipate an interesting voyage of discovery among sessions records and local newspapers, controversial pamphlets and other contemporary documents from which we shall hope to describe other interesting experiments in licensing policy, and as far as possible chronicle their results. Meanwhile, in order just to round off the present fragment of history, we append a few paragraphs of extremely superficial survey of the legislative repentance since the Act of 1830 . 


\section{LIQUOR LICENSING IN ENGLAND}

The widespread discontent of the Justices of the Peace, and of many of the most practical social reformers of the day, with the results of Free Trade in beer, led, for the next few years, to very little result. ${ }^{1}$

A strong House of Commons Committee of 1834, appointed at the instance of James Silk Buckingham, M.P., to investigate the prevalence of drunkenness, is important as marking the first appearance at Westminster of the Temperance Party. In spite of valuable and voluminous evidence, which, by Buckingham's energy, was reprinted $^{2}$ and widely circulated, nothing was done. A House of Commons Committee in 1833 had already found abundant confirmation of the evil results of the new beer-houses, but

1 A full examination of the effect of the Beer Act of 1830 on the licensing poliey of the Justices, on the brewers' monopoly and the tied-house system, and on panperisul and erime, must be left for a subsequent volume. The student may be referred, in addition to the authorities yuoted, to the following important sourees prior to 1835, viz. the Report of the House of Commons Committee of 1834 on an infuiry into drunkenness, presided over by J. S. Buckingham, hefore which evidence was given by Place, Chadwick, and the earliest temperance reformers; the volume entitled Evidence on Drunkenness presented by the House of Commons by the Selcet Committee (1834), 591 l'p. octavo; the reports of the Assistant Commissioners in the First Appendix to the boor Law Inquiry Commissioners Report of 1834; the evidence taken by the Factory Commissioners in 183:3; and the works of Kay, Gaskell, and Thaekrah.

" See the thick volume entitled Evidcnce on Drunkenness presented to the House of Cumnons by the Select Committee (1S34). 
led to no important change. The second Beer Act of 1834 (4 and 5 William IV. c. 85) imposed the futile requirement that, for sales on the premises, intending beer-sellers should, except in London, produce a certificate of personal character signed by any six rated householders of the parish, and raised the excise fee from two to three guineas. In 1840 , by the third Beer Act ( 3 and 4 Vict. c. 61 ), a similar certificate was required as regards persons subsequently entering the trade on each annual renewal; and such persons were restricted to occupiers of $£ 15$, £11, or $£ 8$ rateable value in London, provincial towns, and rural districts respectively. But it still remained possible for the number of beer-shops to be indefinitely multiplied. Under these circunstances no effective regulation of the traffic was possible.

Up and down the country the Justices found themselves paralysed by the Beer Act, by the public opinion which had brought it into law, and by an administration of the Excise Department in fullest accord with the spirit of Free Trade in liquor. It was useless to attempt any restriction in the number of fully licensed houses when beer-shops could be multiplied ad libitum. In many cases it appeared the best policy to press the beer-shop-keeper to accept 


\section{LIQUOR LICENSING IN ENGLAND}

a spirit licence, in order that his premises might come under some control. ${ }^{1}$ On the whole, the tendency for the next two decades after 1830 seems to have been for the Justices to take up a purely ministerial attitude. Whatever control or authority there was to be exercised over the sale of liquor was left to the decision of Parliament, the Commissioners of Excise, and the metropolitan police. In particular, the regulation of the hours of closing, which, as we have seen, had always been decided by the Justices as a condition of their licence, now came to be entirely statutory, ${ }^{2}$ taken up primarily as a matter of police. This legislation was gradual and experimental. "In 1839 a Police Act was passed for the Metropolis, which contained a clause closing public-houses from midnight on Saturday till one o'clock on Sunday afternoon.

1 In a few cases we have traced a great increase in licences since 1830, espeeially in the old eorporate towns. Thus Chiehester (Sussex), with a population in 1831 of 8270 , had, under the close eorporation, twenty-seven licensed houses. In 1891 the population liad only grown to 10,808 , but there were in 1896 no fewer than ninety-two "on" lieenees and fourteen "off" licences (vol. v. of Procecdings of Royal Commission on Liquor Licensing, 1897-99).

2 A elause in the 1830 Aets had preseribed the hours of elosing for the new heer-shops, viz. from $10 \mathrm{r}$.M. to 4 A.M. every night, and from 10 to 1 and 3 to 5 on Sundays (11 George IV. and I William IV. e. 51 and e. 64). The Act of 1834 (see. 6) gave the Justiees power to regulate hours, but this was repealed in 1840 by 3 and 4 Vict. cap. 61, see. 14) (see The Licensing Acts, by d. Paterson, 13th edition (1900), pl. 260, 271). 
This provision was extended to Liverpool in 1842 , to Manchester in 1845, to Newcastle-onTyne in 1846, and subsequently to Sheffield. In 1848 a Bill was passed covering the whole of England, where public-houses were closed from midnight on Saturday to 12.30 P.M. on Sunday, except in London and Liverpool, where the hour was 1 P.M." 1

About the middle of the century we see the effect of the growing force of the temperance movement in the appointment of successive parliamentary committees, whose investigations confirmed the repeated complaints as to the evil results of the unlimited and uncontrolled beerhouses. $^{2}$ But the current in farour of Free Trade was still strong. In 1860 , by the French Treaty Act, the Government could even establish, with much public approval, a new class of drinking-places, by its wine licence to refreshment houses, and a new source of family supply, by its off-licence for wine to grocers' and other retail shops. ${ }^{3}$

I The Temperance Morement, by P. T. Winskill (1592), rol. iii. p. 131 ; see Temperance in the Victorian Age, by Dr. Dawson Burns (1897), p. 176.

2 These Blue-books are dated 1849-50, 1852-53 (in which the reports of the previous inquiries of $1817,1818,1830,1833$, and 18191850 were reprinted), and $1854-55$.

323 and 24 Vict. c. 27 (1860). In 1861 and 1863 spirit-dealers and beer-dealers were allowed to sell by retail in small quantities. 


\section{LIQUOR LICENSING IN ENGLAND}

During these years falls, too, the much debated Liverpool policy of granting a licence practically to every respectable applicant; ${ }^{1}$ which was, as we now find, merely a revival of the experiment tried by several county benches in 1828-30. Not until 1869 eould Parliament nerve itself to retrace the step taken in 1830 and bring all licensed premises under the Justices' control. ${ }^{2}$

The Act of 1869 seems to us to mark practically the first step in the path of legislative repentance. Down to this date, though the fully-licensed public-house was under the Justices, the retailers of table-beer only were, as we have already mentioned, neither enumerated nor inspected, neither licensed nor taxed, by any authority. The beer-shops, cider-shops, and wine-shops, whether for consumption on or off the premises, could open on payment merely of an excise fee. Heneeforth, all these sellers of intoxicating drinks had to obtain the Justices' licence, though the diseretion to refuse a renewal was limited in the case of then existing beershops to the well-known four grounds of refusal. ${ }^{3}$ The privileged status thus given to

1 For this experiment see The Temperance Mlovement, by T. P. Winskill (1892), vol. iii. pp. 135-137.

2 See the Bhue-book of $1866-67$, which led up to the Act of 1869 .

332 and 33 Vict. c. 27 (1869). This privileged status of the 
the "ante-1869" beer-houses is important, as introducing for the first time a limitation of the discretion of the Justices in refusing a licence, and also as making a sharp distinction between the renewal of an existing licence and the grant of a new one. There has been no extension of this distinction. It has, on the contrary, been minimised.

The Act of 1869 gave a like privileged status to the holders of licences for the sale of beer for consumption off the premises, but this provision was repealed by the Acts of 1880 and 1882, so that renewals may be refused in these cases without cause assigned. The Act of 1872, consolidating the law as to offences by publicans, with some minor reforms of value, further strengthened the Justices' power, ${ }^{1}$ and gave them renewed discretion as to the hours of closing elsewhere than in the metropolis-a discretion since limited by the Act of 1874 , which fixes the present closing hours. An inconclusive parliamentary inquiry in 1877-78 led only to another thick Blue-book.

Four more statutes remain to be cited, all

"ante-1869 beer-honses" was intended to aplly only to their first application to the Justices, and the Act was temporary only. In 1870 the privilege was extended to all subsequent renewals, and the Act was made permanent.

${ }^{1}$ See the Blue-book of 1872 . 


\section{LIQUOR LICENSING IN ENGLAND}

significantly in the direction of restriction. The Sunday Closing (Wales) Act of 1881 made law for Wales and Monmouthshire one of the most important of the conditions imposed by the Justices of 1787 . The Act of 1886 prohibiting the sale of liquor to children for consumption on the premises, and that of 1901 forbidding such sale at all except in sealed vessels, represent an entirely new departure, never thought of by the magistrates of the eighteenth century. Finally, the "black list" established by the Act of 1902 reminds us of the precisely similar provision included in the "articles" under James I. three centuries before.

But the most important part of the history since 1830 is to be found, we think, in the wonderful story of the growth of Temperance organisations and their effect in changing publie opinion. That change, as yet reflected only to a small extent by the contents of the statutebook, and unfortunately not much in the total consumption of aleoholic liquor, ${ }^{1}$ began to be perceptible in legislative projects and parliamentary debates between 1860 and 1870, and

${ }^{1}$ See the statisties given in The Temperance Problem, by J. Rowntree and A. Sherwell (1899). In 1897 the average eonsumption per liead was 1.03 gallons spirits, 0.40 gallons wine, and 31.4 gallons beer per annun (Final Report of the Royal Commission on Liquor Licensing, $1 \$ 99,1 \% 362)$. 
markedly influenced those of the following decade. Since about 1877 , at any rate, it may be traced in the growing stringency of the licensing policy of nearly all benches of magistrates. The outcome of this transformation of opinion sometimes reminds us of the movement of 1786-87, and sometimes, by its contrasts, marks the changes of a couple of centuries.

The popular movement in favour of Local Option and Local Veto recalls one of the widely adopted devices of 1787. On the other hand, such powerful aid to the cause of temperance as has been given by the London County Council was not looked for in the municipal administration of the eighteenth century. Still less could the reformers of that day have contemplated the idea of municipalising the liquor traffic. It never occurred to the Justices of the eighteenth century to bargain with a brewer for the surrender of two or three existing licences in return for one new one, because, as we have seen, it never entered into their heads, or those of the lawyers of the time, that there could be any question of compensation. ${ }^{1}$ And it is only within the last few years that the licensing benches of

3 For a discussion of compeusation, see The Place of Compensation in Temperance Reform, by C. P. Sanger (1901), one of the publications of the Lonton School of Economics and Political Science. 
the present generation have plucked up courage to exercise the discretion which their predecessors under George the Third used so freely, in suppressing licensed houses which were unnecessary for the supply of the legitimate wants of the neighbourhood.'

It is interesting to notice that, whereas in the middle of the nineteenth century the tendency seemed to be to take the licensing and regulation of the liquor traffic out of the hands of the local authorities, and to make it as exclusively part of the national administration as are the Factories and Workshops Acts, the tendency of the last quarter of a century has been to restore it to the sphere of Local Government.

On this note we pause. We prefer to draw no inferences and to come to no conclusion until we have had opportunities of further investigation.

${ }^{1}$ For the case of Sharp $v$. Wakefield ( 1 Appeal Cases, 1891, I. 473), in which this right of the Justices was elaborately argued, and ultimately upheld, see The Licensing Acts, by J. Paterson (13th edit. 1900), pp. 397-407, or vol. ix. of the Proccalings of the Royal Com. mission on Liquor Licensing, 1897-99. 


\section{APPENDIX}

THE MOVENENT FOR THE REFORMATION OF MANNERS

THE Societies for the Reformation of Manners appear to have been established soon after the Revolution, and securing, from 1691 onwards, the patronage of the Queen and repeated commendations from Parliament, they grew rapidly, during the ensuing years, into a large and influential organisation. We need not concern ourselves with the particular forms which they assumed, especially as the several societies were always dying away and being resuscitated, according to the waxing or waning of the feeling that public morals needed to be reformed. The various groups seem to have been composed of very different classes of persons. There were, in the grandest of them, great lawyer's and divines, members of Parliament and other dignitaries in close connection with the Government. Others were composed of clergymen of the Church of England; there was one of Justices of the Peace, and several mainly of tradesmen; there was one of persons connected with parish government in the metropolis; one of constables; and even one of "such as made it some part of their business to give information to a magistrate,"-that is to say, of professional informers. ${ }^{1}$

${ }^{1}$ The main source of information for the earlier societies is $A n$ Account of the Rise and Progress of the Religions Societies in the City 


\section{LIQUOR LICENSING IN ENGLAND}

These Societies for the Reformation of Manners, which sprang up in most of the corporate towns as well as in the metropolis, set themselves to carry into execution the various royal proclamations "for the encouragement of piety and virtue, and for the preventing and punishing of vice, profaneness, and immorality," which we have already described. They repressed licentiousness and disorderly conduct rather than crimes against life or property. "We are told that many thousands have been brought to punishment for swearing and cursing; that a multitude of drunkards and profaners of the Lord's Day, some of whom kept, as it were, open markets within a few years past, have been made examples of . . . that hundreds of disorderly houses, which were little better than stews, and nests for thieves, clippers, and coiners, etc., have been rooted out and suppressed ... public disorders are remarkably cured; and, in short, vice is afraid and ashamed to show its head, where within a few years past it was daring and triumphant." I What the societies actually did seems to have been to pay the expenses of the prosecution of criminals, to encourage voluntary inforof London, etc., and of the Endeavours for Reformation of Manners which hove been made therein, by Josialı Woodward (London, 1698); see also An Address from the London Society for the Suppression of Vice (London, 1803); An Account of the Sociclies for lieformation of Henners in London and Westminster and Other Parts of the Kingdom, Anon. (London, 1699); An Aecount of the Proyress of the Reformation of Manners in England, etc., Anon., 12th edition (London, 1704); The Poor Man's Plea in Relution to all the Deelarations, Acts of Parliement, etc., which hive been male or publish re for a lieformation of Nanners and Suppressing Immorality in the Nation, by Daniel do Foo (Lomlon, 1698): Wilson's Memoir's of the Life aml Times of Daniel de Foe (1830), i. 1.p. 301-302.

1 Quoted, in relation to the socicties of 1690-1710, in An Address fiom the London Society for the Suppression of Vice (London, 1803), 1. 79 . 
mation as to breaches of the law, and, occasionally, at any rate, to employ paid officers, who were often sworn in as constables or deputy constables, to get up cases and apprehend offenders. Thus, when in 1698 the inhabitants of the Tower Hamlets were "much perplexed by pilfering the people, picklocks, housebreakers, and such ill persons," and annoyed by scenes of open profligacy, which the Justices of the Peace did nothing to repress, the local Society for the Reformation of Manners set to work, and were soon able to report that "by means of this Society alone abont 2000 persons have been legally prosecuted and convicted, either as keepers of houses of bawdry and disorder, or as whores, night-walkers, and the like. . . . They have also been instrumental to put down several music houses, which had degenerated into notorious nurseries of lewdness and debauchery." I

It is needless to say that this repressive activity was wholly directed against the drunkenness and immorality of the humbler classes, not against the licentiousness of the rich. This made them unpopular with the people, and called forth the animadversions of De Foe. His Poor Man's Plea was a sturdy protest against the prevailing tendency to repress, with savage punishments, the disorderly amusements and licentiousness of the common people, whilst allowing practical freedom to the rich to be as idle and vicious as they pleased. "These are," he said, "all cobweb laws, in which the small flies are catched, and the great ones break through. My Lord Mayor has whipped about the poor beggars, and a few scandalous whores have been sent to the House of Correction; some alehouse-keepers and vintners have been fined for drawing drink on the Sabbath day, but all

1 Woodward's Account, pp. 74, 78, 79. 


\section{LIQUOR LICENSING IN ENGLAND}

this falls upon us of the mob, as if all the vice lay among us. . . The very benches of our Justices are infected. 'Tis hard, gentlemen, to be punished for a crime by a man as guilty as ourselves; this is really punishing men for being poor, which is no crime at all." 1 After the death of Queen Anne the Societies for the Reformation of Manners lost the patronage of the Court and of the fashionable world ; but they evidently continued to exist, in one form or another, for more than half a century.

In 1786 begins a new outburst of an analogous voluntary association of much broader type. We trace this to the influence of the Rev. H. Zouch, a Yorkshire Justice of the Peace of great energy and ability. ${ }^{2}$ The rapid growth of a new manufacturing population in the West Riding had bronght about an obvious breakdown of the primitive organisation of local constabulary. To quote the panicstricken utterances of the principal newspaper of the neighbourhood, "The overflowings of vice and immorality, the vast increase of crimes, and the precarious situation of property, are such as to call alond for the exertion of every individual who has either the good of his country,

1 Wilson's Memoirs of the Life and Times of Daniel de Foe, vol. i. 1. 290 .

2 The Rev. Henry Zouch, Reetor of Swillington and Tankersley, and chaplain to the Narehioness of Rockingliam, was for many years the most active and influential of the West Riding Justices. His pamplilet, Hints respecting the Public Police (London, 1786), marked by grood sense and ability, seems to have had a wide cirenlation. He was deputed to go to London in 1790 , to confer with the Proelamation Society as to means of improving the police (Leeds Intelligencer, 21st July 1789). On his death in 1795, it was said that, "he displayed an aceurate and comprehensive knowledge of the laws of England, au unbiassed integrity in the administration of justice, and a most con. descending attention to the complaints of the lower classes of soeiety " (Leeds latelligencer, 29th June 1795). 


\section{APPENDIX}

or the safety of his own person or property at heart." 1 Zouch published a pamphlet entitled Hints respecting the Public Police, and brought such pressure to bear on his fellow-magistrates that Quarter Sessions, in April 1786, "earnestly recommencled to the principal inhabitants of all places to agree in uniting together under certain rules and regulations for the better purpose of detecting felons, cheats, vagrants, night-walkers, and night-poachers, pawnbrokers who are often guilty of malpractices, and particularly in receiving stolen goods knowing them to be such, sellers by false weights and measures, persons adulterating or improperly mixing meal, flour, etc., and, in short, all those who are in any way guilty of a breach of the law." 2 The Justices on the same occasion resolved to withhold licences from all public-houses offending against the law, and to organise privy searches for vagrants in their respective districts. ${ }^{3}$ The movement became one for a general vigilance in every branch of local administration. At a subsequent meeting, the Justices required all constables "as soon as may be, to call a meeting of the inhabitants within their respective districts, and to represent to them the necessity there is for all honest men to form themselves into committees, or otherwise to associate themselves as well in aid of the civil magistrate, as to superintend and regulate all parochial matters, more especially relative to the poor and the highways, where the overseers appointed are incapable or are negligent in the discharge of their duty." 4

1 Leeds Intelligencer, 26th September 1786.

2 Quarter Sessions, West Riding of Yorkshire, 24th April 1786 (Leeds Intelligencer, 16th May 1786).

3 Leeds Intelligeneer, 16th May 1786.

4 Quarter Sessions, 16th April 1787 (Leeds Intelligencer, 1st May 1787). 


\section{LIQUOR LICENSING IN ENGLAND}

Committees or societies of this kind, meeting weekly, were immediately formed in many West Riding towns. ${ }^{1}$ We may judge of their work by the following extract from the rules of the Pontefract society:--_"That we will on every proper occasion encourage and assist the varions parochial officers in the execution of their duty, particularly in suppressing all kinds of irregularities or tippling in the alohouses in the Lord's Day, and in searching for vagrants, cheats, etc., and taking them before the magistrates; and also in giving information ourselves, where we have personal knowledge and proof of the breaking of our excellent laws, for the due observance of the Sabbath, and against swearing and other notorious immoralities." 2 That their vigilance and active cooperation with the magistrates had, for the moment, a great effect in repressing disorderly conduct and crime is universally reported, and is probably true, but this ephemeral and purely local movement suddenly gained an importance which it would otherwise have lacked, by the action of Wilberforce, at that time one of the members of Parliament for Yorkshire. Deeply impressed by the prevalence of immorality, he felt, to quote the words written in the secrecy of his diary, that "God has set before me as my object the reformation of (my country's) manners." He was struck by the success of the West Riding magistrates in uniting all the respectable inhabitants of the county for the suppression of breaches of the law, and he set himself, with all his influence among the governing classes, to convert the movement into a

1 Within a month, the Lecels Intelligeneer (23rd May 1786) reports them as formed in several towns. The rules for that of Pontefiact are given in the issue for 19 th Septemher 1786.

${ }^{2}$ Leeds Intelligencer, 19 th Sepitember 1786. 


\section{APPENDIX}

national one. In his hands it became like the earlier movement of 1690-1710, principally a campaign against licentiousness and profanation of the Sabbath, rather than one for the protection of life and property. He induced the Privy Council to issue a proclamation on the lines of those issued at the beginning of each reign; the Secretary of State to write to all the lord lieutenants to incite the Justices to activity, and a large number of distinguished persons to form a society to see that the various laws regulating personal conduct were put in force. The proclamation declared the royal intention to punish "all manner of vice, profaneness, and immorality," forbade "playing on the Lord's Day at dice, cards, or any other game whatsoever, either in public or private houses," and commanded special energy in the enforcement of the laws against "excessive drinking, blasphemy, profane swearing or cursing, lewdness, profanation of the Lord's Day, or other dissolute, immoral, or disorderly practices ... public gaming-houses . . unlicensed public shows, interludes, and places of entertainments ... loose and licentious prints, books, and publications," and the supplying of refreshments during the time of divine service. $^{1}$ But though the scope and wording of the proclamation reveals Wilberforce's own preoccupation with the personal morals of his fellow-citizens, the Home Secretary's covering letter lays stress upon "the depredations which have been committed in every part of the kingdom, and which have of late been carried to such an extent as to be even a disgrace to a civilised nation," and urges action "for the preservation of the lives and properties of His Majesty's subjects." 2 These two strains,

1 Proclamation, 1st June 1787; in London Gazette, 2nd June 1787.

2 Lord Sydney's Letter of $23 \mathrm{rd}$ June 1787, given in full in $A$ General 


\section{LIQUOR LICENSING IN ENGLAND}

that of "depravity, dissipation, and profanation of the Lord's Day" on the one hand, and that of "alarming depredations on life and property" on the other, are about equally mixed in the resolutions which Quarter Sessions everywhere hastened to pass. ${ }^{1}$

We have elsewhere described the spurt of vigilance and activity which, doubtless in consequence of the Royal Proclamation and the Home Secretary's letter, the Justices in 1787-88 everywhere put into execution of the vagrancy and licensing laws. Meanwhile, the society established by Wilberforce and his aristocratic friends was setting energetically to work, holding in 1790 a national conference of two Justices of the Peace from each Quarter Sessions, prosecuting the purveyors of blasphemous or obscene literature and indecent shows; ${ }^{2}$ getting convicted those who opened places of entertainment on Sunday, gaming-houses or places of resort for immoral purposes, stopping the collusive transfer of liquor licences, enforcing the vagrancy laws, and "maintaining the sancity of the Lord's Day." That this agita-

Plan of Parochial and Provincial P'olice, hy W. M. Godschall (London, 1787).

${ }^{1}$ Among these we may cite Gloucestershire, Berkshire, Somerset, Flint, Surrey, Norfolk, Lincoln, Northamptonshire, Cumberland, North and West Ridings of Yorkshire, Laneashire, Midllesex, and Kent, which we have examined, either in the MS. Mimntes or in the reports in local newspapers for 1787-88. See also A General Plan of P'aroehial Police, by W. M. Godsehall (Loudon, 1787); Correspondence of William I'ilberforce, by R. and S. Wilberforee (London, 1840), vol. i. 1. 130, ete.; Report of the Committee of the Society for carrying into ellect His Majesty's Proclamation against Vice and Immorality (London, 1799); and the "Ironical Defence of Vice and Immorality," in the Annual Register for 1788 (vol. xxx.), p. 140.

2 Among the publications it songht to suppress was Paine's Age of Reason. 
tion for setting the law in motion produced a considerable effect is abundantly proved by contemporary evidence. ${ }^{1}$

1 Thus, to quote only one case, we read that "in the town of Stroud a great diminution of irregularity and misbehaviour has of late been observed, to the comfort and satisfaction of the inhabitants. Such a change shows what may be effected in time by the uniform but gentle perseverance of a worthy minister, when supported by a few active and exemplary characters. The present High Constable has proved that our laws give full power for the suppression of every enornity, when the execution of them is eonsigned to men of spirit and integrity" (Bristol Gazette, 10th April 1788). The following record of the action taken in a Hertfordshire village gives us a picture of its contemporary loeal government. "An extraordinary meeting of the committee was held on 31st Oetober 1787, for the purpose of taking into eonsideration the Proclamation for preventing and punishing profaneness, vice, and inmorality, by order of the Rev. $\mathrm{Mr}$. Weston ; present (eight names and the chief constable).

Words of the Act:-No drover, horse courier, waggoner, buteher, higgler, or their servants shall travel on a Sunday.

Ordered that the above be prevented so far as relates to carriages, punishments 21s.; and for default, stocks two hours.

No fruit, herbs, or goods of any kind shall be cried or exposed to sale on a Sunday. N.B.-Goods forfeited.

No shoemaker shall expose to sale upon a Sunday any boots, shoes, or slippers, $-3 \mathrm{~s}$. $4 \mathrm{~d}$. per pair, and the valne forfeited.

Any persons offending against these laws are to be prosecnted, except butchers, who may sell meat till nine o'eloek in the morning, at which time all barbers' shops are to be shut up, and no business to be done after that time.

No person without a reasonable excuse shall be absent from some place of Divine Worship on a Sunday-1s. to the poor.

The constables to go about the town, and partieularly the Cross, to see that this is complied with, and if they find any number of people assembled together, to take down their names, and return them to the committee that they may be prosecuted.

No innkeeper or alehouse-keeper shall suffer any one to eontinue drinking or tippling in his house.-Forfeit 10s. and disabled for three years.

Ordered that the constables go to the public-houses to see that no tippling or drinking is done during Divine Service, and to prevent drunkenness, etc., any time of the day. 
But in a very few years the activity of the "Proclamation Society," as it was usually termed, came to a natural end; its meetings ceased to be held, and though it lingered on into the nineteenth century, it calls for no further notice.

The voluntary associations of 1690-1710 and 17861795 were succeeded by a third movement which started in 1802 . We find, in that year, established a "Society for the Suppression of Vice and the Encouragement of Religion and Virtue throughont the United Kingdom," which took up the work of the moribund "Proclamation Society," but confined its operations still more exclusively to the prevention of "profanation of the Lord's Day" and the suppression of indecent literature and sexual immorality. This society appears to lave found its supporters entirely among the rising Evangelical party, and to have had no very close comnection with the official or governing class. We have but scanty records of its work, which was carried on by three committees, each meeting weekly, but though branches or imitations of this society long continued to exist in many towns, the organisation does not appear to have exercised any important influence on local government. ${ }^{1}$

Persons who sell by false weights and measures in market towns -6s. 8d. first oflence; 13s. 4il. second oflence; 20s. third, and pillory.

Ordered that the constables see that the weights and measures were good and lawful" (Fragments of Tuo Centuries, by Alfrerl Kingston (Royston, 1893), 11. 26-27).

1 Proposal for establishing a Society for the Suppression of Vice (London, 1802); Address to the Publie from the London Society for the Suppression of Vice (London, 180:3). For a similar society at Gloncester in 1818, and at Carmarthen 1816-20, see Carmarthen Journal, 6th November 1818, and 14th January 1820 ; for one nowly formed at Leeds in 1825, see Leeds Intellifencer, 31st Mareh 1825. 
These three distinct outbreaks of voluntary associations for reforming the manners and morals of the poor were only manifestations of a spirit which we trace continuously in the moralists and statesmen of the whole period. What the educated classes always had at heart was the reclamation of "the lower orders" to a life of regular and continuous work." For this desire there were several different motives, variously combined. What Queen Mary and Wilberforce were most concerned about was the fact that the common people were defying God's law, and incurring the penalty of eternal damnation. The magistrates, manufacturers, and quiet folk generally wanted, like the Home Secretary of 1787 , to stop the depredations on life and property. To the employer's and "principal inhabitants" of each district the worst part of the evil seemed to be the waste of time and money by the poor, ${ }^{2}$

1 "A journeyman," it was said in 1749, "can no more afford to throw away his time than a tradesman can his commodity; and the best way of preventing this useful body of men from this species of extravagance is to remove from their sight all temptation to idleness" (An Account of the Origin und Effects of the Police set on Foot by the Dulie of Nenceastle on a Plan of Henry Fielding, London, 1758).

2 "How often do we see the whole inlabitants of a country village drawn from their harvest work to see a cudgel playing or a cricket match? and how common is it to behold the vulgar people thronging from every quarter of the Metropolis to some of its environs to partake of the silliest pastimes that can be invented for the excite. ment of their curiosity. On these occasions the poor do not only suffer from the loss of a half or whole dlay's labour, which is often to them a matter of great importance, but also spend as much as they can earn in another day, or perhaps two, and besides disqualify themselves by intemperance for working on the next. . . It is a mortifying consideration that so many of our labouring leoplte misspend at least a fourth part of the week, and an equal proportion of its earnings, in the most inle gratification and most destrnctive intemperance" (London Chronicle, 4th-6th Oetober 1761). "To prevent gaming among the lower sort of people is principally the business of society; and for this plain reasen, because they are the most useful 


\section{LIQUOR LICENSING IN ENGLAND}

which checked production and increased the poor rate. All three motives pointed, as it happened, to one main device, the adoption of which was accordingly always attempted. What seemed to be required was to suppress the opportunities for the idleness, drinking, and licentiousness of the common people. This meant the suppression, wherever possible, of the old fairs and village festivals, a reduction in the number of alehouses ${ }^{1}$ and the prohibition of all games and amusements in them, ${ }^{2}$ and as strict a limitation as possible of musical and theatrical performances. Each ontburst of zeal for the reformation of manners was accordingly marked, as De Foe complained, by attempts to put down popular amusements. This is specially characteristic of the movement of 1786-95. "In London and other large towns," urges one thoughtful critic in 1787 , "diversions calculated to slacken the industry of the useful hands are innumerable; to lessen, therefore, the number of these is the business of the magistrate." 3 member's of the society, which by such means will lose the benefit of their labonr" (Charge to the Grand Jury of Westminster, June 1749, by Henry Fielding (London, 1749), 1. 161).

1 "These little pot-honses, it is a known fact, are the rendezvous of these nocturnal villains, where they plan their depredations, and where not infrequently they divide their spoil. The landlord connives at their malpraetices-it is his interest so to do-perhaps his daily bread depends upon it-perhaps he is connected with them" (Leeds Intelligencer", 25th $A_{\text {pril }} 1786$ ). "There are villages in remote country places which ean date the commeneement of their poor rates from the introduction of a public-honse" (Bristol Journal, 19th January 1788).

2 " $\Lambda$ mongst the number of diversions that call for redress are those earried on in public-houses, such as cards, dice, draughts, shuflle-boards, billiards, and skittles. These are the places that rol, the journeymen and labourers of their time, their little property, and their less morals" (Bristol Journal, 18th $\Lambda$ ugust 1787).

3 "Reflections on the great importance of magistrates licensing alehouses to proper persons," in Bristol Journal, 18th $\Lambda$ ugust 1787. 
"As this is the season when country feasts, wakes, etc. usually begin," observes the principal newspaper in Yorkshire in 1786, "a correspondent earnestly recommends it to the ministers and officer's in every parish to prevent them from being held on the Lord's Day. Indeed, it would be much better to suppress these feasts entirely, for, as the Rev. Mr. Zouch justly remarks in his excellent pamphlet on the police, it is found by long experience that, when the common people are drawn together upon any public occasion, a variety of mischiefs are certain to ensue; allured by unlawful pastimes, or even by vulgar amusements only, they wantonly waste their time and money to their own great loss and that of their employers. Nay, a whole neighbourhood becomes unhinged for many days, quarrels are too often promoted, and the young and inexperienced are initiated into every species of immorality." 1 The same period saw the suppression of many unnecessary alehouses in small villages, and, in many places, also a partial and temporary probibition of bull-baiting. ${ }^{2}$

${ }^{1}$ Leeds Intelligencer, 20th Jume 1786. It is interesting to find the zealous Zouch specially reprobating, in this connection, "the practice of performing oratorios in country churches," which he thinks "very exceptionable, not only by the indecencies committed therein, but by giving occasion for great numbers of persons of all kinds to be brought together, so that the adjoining villages do often become scenes of drunkenness, disorder, and riot." The Arehbishop of York has disapproved of "introdncing sacred music in this way" (Hints respecting the Public Police, by the Rer. H. Zouch, J.P., p. 7).

2 At the General Quarter Sessions of the Peace, held at Stanford in October 1789, it was ordered "that there shall be no bull-running on the said 13th day of November, nor at any other time, as bullrunnings are productive of vice, profaneness, immorality, disorder, riot, drunkenness, and mischief among many people, inliabitants of this borough and the neighbourhood thereof; of every species of inhumanity in the lower order of the people to an unhappy animal; and of great annoyance, danger, and delay to all travellers passing 
There is, to our modern feelings, something unsavoury in this combination of concern for the spiritual welfare of the poor and for the security and profit of the rich, especially when it led merely to attempts to deprive the lower orders of their margin of leisure and opportunities for amusement. The sturdy protest of De Foe was, in fact, repeated in 1787 by an outspoken country gentleman. At a meeting of the Norfolk Justices (4th Angust 1787), "after many observations had been made upon the depravity of the lower orders of the people, and the necessity there was for lessening the number of alehouses and other places of fashionable resort, Sir Thomas Beevor reprobated the plans proposed. He said 'he was very far' from thinking the sum of iniquity in this country was greater than it had been, and still further from believing the poor were either more vicious or more abandoned than their forefathers. That it was, and ever had been, the cant language of every age to condemn the present time and to applaud the past. That, from his reading and acquaintance with the history of England, he would venture to affirm that the police of it was never more strictly attended to than at present ... that this was a frivolous rather than a wicked age; but if gentlemen thought otherwise, and really wished to amend it, he was ready to concur most heartily with them in the good design. He must, however, warmly reprobate the plans proposed as both ineffeetual and oppressive. They are,' said he, 'ineffectual and partial as beginning with, and being confined solely to the reformation of the lower class of people; they are oppressive, as they tend to deprive the poor of a great part of that scanty pittance of bappiand repassing mpon the King's Highway in this Borough" (Lincoln, lietland, and stemford Iforery, 9th Octuber 1789). 
ness which their lot in this life can afford.' Sir Thomas Beevor went on to recommend that the Justices themselves should set an example of temperance." The usual resolution was, however, passed. ${ }^{1}$

${ }^{1}$ Leeds Intelligencer, 4th September 1787. 



\section{INDEX}

Acts of Parliament--

11 Henry VII. c. $2: 6,9,13$

19 Henry V1I. c. $12: 6$

5 and $6 \mathrm{Edw}$. VI. c. $25: 5,6,7$, $9,14,98$

$7 \mathrm{Edw}$. VI. c. 5 : 18,19

11 Jac. I. c. $9: 62$

21 Jac. I. c. $7: 19$

12 Car. II. c. $25: 19$

15 Car. 1I. c. $14: 19$

22 and 23 Car. II. c. $26: 19$

12 and $13 \mathrm{Wm}$. III. c. $11: 22$

9 Anne c. $16: 7$

9 Anne c. $23: 19$

2 Geo. II. c. $17: 24,25$

2 Geo. II. c. $28: 5,6$

$6 \mathrm{Geo}$ II. c. $17: 25$

9 Geo. II. c. $23: 25-26,78$

10 Geo. II. c. $17: 19$

16 Geo. II. c. $8: 29,33$

17 Geo. II. c. $17: 37$

$24 \mathrm{Geo}$ II. c. $40: 37,38$

26 Geo. II. c. $13: 37,79$

26 Geo. II. c. $31: 7,36,38,62$

28 Geo. II. c. $19: 38$

29 Geo. II. c. $12: 36,37$

29 Geo. II. c. $25: 56$

30 Geo. II. c. $19: 19$

32 Geo. III. c. 59 : 19

42 Geo. III. c. $38: 115$

48 Geo. III. c. $143: 47$

56 Geo. III. c. $104: 99$

4 Geo. IV. c. $51: 110$

5 Geo. IV. c. $54: 110$

9 Geo. IV. c. $61: 19,113$

11 Geo. IV. and 1 Wnil. IV. c. $51: 124$
Acts of Parliament-

11 Geo. IV. and $1 \mathrm{Wm}$. IV. c. $64: 115$

4 and 5 Wm. IV. c. $85: 130$

3 and 4 Vict. e. 61 : 130

23 and 24 Vict. c. $27: 131$

25 and 26 Vict. c. $22: 19$

32 and 33 Vict. c. $27: 132,133$

35 and 36 Vict. c. $94: 133$

37 and 38 Vict. c. $49: 100$

43 and 44 Vict. c. $20: 19$

44 and 45 Vict. c. $61: 134$

49 and 50 Vict. c. $56: 134$

1 Edw. VII. c. $27: 134$

2 Edw. VII. c. 28 : 134

Allermen, city of London, 64 ; licensing work of, 109

Ale, increase in consumption of, 17-18. See also Beer

Alehouse-keepers, rules for, 59-60

Alehouses, distinction between inns and, 5 ; licensing of, $i b$. ; sup. pression of, by Justices, 6, 10 $12,15,68 \cdot 74,149$; by Judges of Assize, 13 ; power of Jus. tices to suppress repealed, 113 ; multiplication of, $15,33,42$, 105,106 ; licences for, easily obtained, 41 ; given to needy persons, 44; in villages and country places, $42,44,46,51$. 103 ; canse of, innumerable, 43 ; number of, in Westminster. 40.41 ; in Leeds, 16 ; withont a licence, 51 ; rednction in number of adrocated, 51, 53; number of, leduced, 53,58 . 


\section{LIQUOR LICENSING IN ENGLAND}

59,113 ; preference given to, 78 ; licensed to sell spirits, 80 , 105 ; statistics of, $80-81,82$, 108 ; temporary ones, at fairs, 99 ; "free trade" in, 110 ; owned by brewers. See Tied IIorses

Althorp, Lord, 125

Anne, Queen, 140

Articles of $1618,54,62,102$, 134

Assize, Judges of. Stee Jirliges

Aylesbury (Bucks), 103

Aylesford (Kent), 55

Bacon, Nathaniel, 10

Bagshot (Surrey), 19

Ballard, A., 46

Bampton (Oxon), 56, 66

Barclay, C., 93

Barnsley (Yorks), 53

Barnstaple (Devon), 99

Bars, drinking, 78

Bathsorum Division (Somerset), 64, 69

Bathurst, Lord, 27, 28, 30

Beadles, not accepted as sureties, 56

Beccles (Suffolk), 66

Beer, assumed to be a necessar'y of life, $2,86,110,111,118$; sale of, in unlicensed premises, 17 ; increase in consumption of, 17-18; statistics of duty on, 48 ; preference given $t o$, over spirits, 78, 79, 111: quality of, in "tied horses," 89,91 ; price of, $92.93,106,111$; sale of, at fairs, 98-100 ; brewing of, withont a licence, 98.99 ; "free trade" in, 106, 110, 111, 113, 115, 131; effects of "free trade" in, 116-126 ; decrease in consumption of, 109; "home-brewed," retailed withont licence, 110 ; "off" sale of, without licence, 113 ; tax on, withdrawn, ib. ; decrease in number of licences for sale of, ib. ; Report of llouse of Com- mons Committee on Sale of, by retail (1830), 114; universal sale of, 118; average consumption of, per head, 134

Beer Act, the First (1830), 115, 116 ; petitions for repeal of, 124 ; effects of, 128 ; powers of Justices rendered useless by, 129-130

the Second (1834), 129

the Third (1843), 129

Beer-shops, no licence required for, 115; in Liverpool, 116 ; illcrease in number of, 117 ; in Birmingham, $i b$; set up by brewers, 117, 118; hours of closing, 122, 130; evils of unlimited number of, 131 ; brought under control of Justices, 132 ; privileges of those established before 1869,133

Beevor, Sir Thomas, 150, 151

Berkshire, 60, 61, 62, 70, 89, 102, 144

Bethnal Green, 94

Beverley (Yorks), 104

Birmingham (Warwickshire), 99, 117

Bishop Wearnouth (Durham), 47 Bishops, attitude of, towards Act of $1743,30,31$

Black list, 11, 134

Bodmin (Cornwall), 104

"Books of Orders," 10

Bowles, John, quoted, $86^{\circ}$

Brandy, importation of foreign, 20 ; English, namufacture of, encouraged, 21 ; "Parliament," 25

Breweries, Report of House of Commons Committee on (18181819), 91, 93

Brewers, promotion of liquor traftie by, 43 ; as sureties for good behaviour of publicans, 57 ; monopoly of public-honses in hands of, $87-93,112$; break. down of monopoly of, 105 ; price of porter fixed by, 92 ; "home" brewers, 110; "re. 
tail" brewers, $i b$. ; new type of, 117 ; attitude of, towards "free trade" in beer, 112, 113 Brewing, encouragement of, 3 ; development of, 87-88; private, 82 ; without a licence at fairs, 98.99

Blewster Sessions, origin of, 5,6 ; referred to, $36,57,76,77,80$, 85 ; description of scene at, 45 ; rules prescribed by Justices in, 54; at Barusley, 53 ; at Bampton, $66^{\circ}$; at Salisbury, 70 ; at Sheffield, 71 ; special, 66 ; recommendations to Justices in, 79 ; appeal from, to Quarter Sessions permitted, 113

Brighthelustone (Sussex), 63-64 Brightou. See Brighthelmstone Brougham, Lord, 125

Buckingham, James Silk, M.P.: 103,128

Buckinghamshire, 105

Bull-baiting, 53, 87, 149

Burns, Justice of the Peace by, quoted, 102

Burns, Dr. Dawson, 110, 131

"Bush-houses," 99

Cambridge, 27

Carlisle (Cumberland), 70

Carmarthen, 146

Cartaret, Lord, 26

Carter, Bonham, 7

Cartwright, J. J., quoted, 12

Certificates of good character, 54, $58,63,66,129$; requirement of, abolished, 113

Chadwick, Elwin, 128

Charter, of Viutners' Company, 19 ; of St. Albans, $i b$.

Chelsea (Middlesex), 40, 74

Cheshire, 124

Chester, 124

Chesterfield, Lord, 29

Chichestel' (Sussex), 104, 130

Children, sale of liquor to, 134

Cider, tax on, withdrawn, 113

Cicler-shops, 132
Clerk of the Peace, fees received by, 47 ; blank licences filled up by, $i b$.

Clerks, Justices', fees received by, 43

Closing, hours of, $11,60,96,108$, $119,131,133$; in beer-shops, 122, 130 ; uot tixed by Parliament, 9 ; prescribed by Justices, 40; not enforced in St. Luke's, 41

Clutterbuck, Robert, quoted, 19

Cock-fighting, 52, 53, 54

Coffee-houses, alcoholic drinks sold in, 17 ; in Shrewsbury, ib.

Colquhoun, Dr. Patrick, 77, 94

Company, Vintners', 19 ; Distillers', 20

Compensation, 135 ; instances of suppression of public-houses without, $8,68,85,101$, 108

Coustable, High, of Stroud, 145 ; Chief, of Brighthelmstone, 64

Constables, licensed victuallers as, 35,56 ; required to visit publichouses, 65 ; of Westminster, instructions to, 72 ; directions to, by Fulham Vestry, 74 ; a society for Reformation of Manners formed by, 137 : special, sworn in, 139

Constabulary, breakdown of local, 180

Corfe Castle (Dorset), 8

Cornwall, 106

Conling, Samuel, 39

Cox, J. C., 10

Crimes, produced by drunkenness, 2 ; encouraged by retailers of spirits, 35 ; originated in public-houses, 46 ; diminution of, 82

Cruden, R. P., 19

Cumberland, 144

Dalton, Michael, 11

Danvers, Sir John, 94

Davenport, Elward, 110

Daries, J. S., 11 


\section{LIQUOR LICENSING IN ENGLAND}

De Foe, Daniel, 17, 20, 138, 139, $140,148,150$

Denham, Baron, 13

Derby, 60, 61

Devonport. See Plymouth Dock

Devonshire, 71, 103

Disorderly houses, suppression of, 138

Distillation, of spirits, a monopoly, 20 ; monopoly destroyed, $i b$.

Distillers, free to open retail spirit shops, 21, 33; and to permit free sale of spirits in shops, 21 22 ; probibited from retailing even with licence, 33 ; promotion of liquor trade by, 43 ; ownership of licensed premises by, 88

Distillers' Company, 20 ; power to inspect spirits sought for, 22

Distilling, encouragement of, by Government, 3, 21 ; illicit, 38, 48,82 ; development of, $87-88$ Doncaster (Yorks), 104

Doran, Dr., 34

Dorchester (Dorset), 12

Dorset, 123

Dover (Kent), 104

Dowell, S. O., 18, 19, 20, 110, 115,116

Dram-shops, in London and Westminister, 22-24; description of one, 23; unlicensed, in London, 36 ; licence of, to lapse, 55 ; refusal to license, 57 ; suppression of, at Sheftiel l, 71

Drunkenness, from free sale of gin, 22 ; trom free sale of beer, 116 ; prevalence of, 28,107 ; in London, 22, 23-24, 39 ; in villages, 44, 149; in manufacturing districts, 51, 52; at fairs, 98,99 ; laws against, neglected, 32 ; proposed tax on, 42 ; Report of House of Commons Committee on, 125-126, 128

Durham, 47, 66, 106

Duties, preferential, on manufacture of brandy, 21 ; on sale of spirits, $25,33,81,105$; on mannfacture of spirits, 52 ; on sale of gin, 32 ; statistics of, on malt and British spirits, 48 ; on beer, $i b$.

Earle, John, quoted, 18

Early closing, 49. See also Clusing, hours of, and Sunday Closing. Edinburgh Review, 95, 111

Ellwards, Thomas, LL.D., 95

Essex, 58, 61

Estcourt, 111

Excise, Commissioners of, 99, 130

duty, on spirits, 25 ; on ale 47

Exeter (Devon), 13

Factory and Workshops Acts, 136

Commissioners, 128

Fairs, sale of beer at, $98-100$; suppression of, 148, 149

Falmouth (Cornwall), 103, 104

Faversham (Kent), 104

Fazeley (Staffs), 99

Fearon, H. B., 79

Fees, received by Justices' Clerks, 43 ; received by Clerk of the Peace, 47

Felons, societies for the prosecution of, 141.142

Féret, C. J., 1, 74

Fielding, Hemry, 33, 76, 148

Flint, 144

Flower, Richard, 88

Frampton, Mary, 123

"Free trade" in beer, 112-113, 115,131 ; effects of, 116-126

Freemen, of 'Vintuers' Company. 19

French, R. V., 13, 27

Frome (Somerset), 65

Fulham (Middlesex), 74

Gaming, 40, 65, 72, $74,124,143$, 144,148

Gardiner, 99

Gaskell, 128 
Gentleman's Magaine, 22, 27, 30, $39,42,43,45$

Gin Act, the First (1729), 24-25; repeal of, 25 ; effects of, 38

the Second (1736), 25-26; not approved of by Walpole, 27-28; effects of, $28.29,38$; repeal of, 29

Gin, free sale of, 20 ; excessive drinking of, 22, 28; excise duty on, 25

"Gin Lane," 34

Gin palaces, rise of, $78,120-121$

Gin-shops, 40, 120

Gisborne, T., 76

Gloucester, 68, 146

Gloucestershire, 60-63, 69, 144

Godschall, W. M., 144

Goulburn, 113

Gravesend (Kent), 19

Great Glenham (Suflolk), 62

Grocers' Licence. See Shops

Hammersmith (Middlesex), 74, 94

Hampshire, 103, 118

IIansard, 92, 109, 111, 112, 113, $115,124,125$

Hertfordshire, 145

Hervey, Lord, 31, 42

Hey, William, 54

Hobhonse, Sir J. C., 113

Hogarth, 34

Holborn (Niddlesex), 39, 75

Holland, Lady, 110, 111, 116

Horseley (Glos.), 69

Hours of closing. See Closiny

Hull (Yorks), 104

Huskisson, 111

Hyde, Willianı, 94

Iles, Miss C. M., 1

Informers, a Society for the Reformation of Manners formed by, 137

Inns, distinction between inns and alehouses, 5: might be indicted under common law as a nuisance, $i b$.; brought under regulation, ib,
Ipswich (Suffolk), 66

Islay, Earl of, 26

Jeaffreson, J. C., 10

Jefirey, 111

Jekyll, Sir John, 25

$J$ udges of Assize, enforcement of Privy Council Orders by, 12 . 14 ; suppression of alehouses by, 13

Justices' Clerk, fees received by, 47

Justices, liceusing powers given to, $5,6,19$; suppression of unnecessary althouses by, 6 ; administration of Licensing Act (1552) by, 9-14; "articles" drawn up by, 11, 54, 62 ; motives of, in granting licences, $15,16,42-43,44$; collapse of authority of, 26 ; condemna. tion of licensing policy of, 31 ; lowers of regulation neglected, $33-36,40,41,43,47,102$; authority of, male nore effective, 36.38 ; laxness in granting of licences, $41,43,44,46$, 105-108; at Brewster Sessions, 45 ; powers of regulation, and discretion in licensing exercised by, $34,49-50,52-74,141$; incitel to activity by Privy Council, 53, 143; confusion of mind between judicial and administrative duties, 56 ; use of local option by, 62, 103 ; arbitrary authority of, condemned, 85, 97-98, 108 ; approved of by Tories, 86 ; liscretionary powers of, limited. $96,113,133$; power of, to suppress alehouses, repealed, 113 ; powers rendered useless by Beer Act, 129-130 ; control of, over all licensed premises, re-establisherl, 132, 133; a Society for the Reformation of Manners formed by, 137

of Mirdlesex, 41, 76-79, 87, 93. $95,100,109$ 
Kay, 128

Kensington (Midrllesex), 74

Kent, 144

Tient (distiller), 29

lirby (Essex), 62

Laissez-fuire, loctrine of, prevalent, 87 ; recommended by Committee of Honse of Commons, 98

Lancashire, 52, 144

Lancaster, 104

Larwood, J., 10

Lecky, Rt. Hon. W. E. H., 26

Leeds (Yorks), 46, 54, 58-59, 60, $61,104,107,146$

Lees, F. R., 26

Legislation regnlating liquor trade. See Regulation

Leonard, Miss E. M., 10

Licences, for alehouses, 5, 7, 41, $51,58,80-81,82,105,106$, 110,113 ; for sale of wine, 19, 20, 131 ; Royal, 19 ; for retail sale of spirits, 21,47 , s0, 81, 82, 113; refnsal to grant new, $31,50,57,58,59$, $73,80,95,104,105,108,133$ : granted indiscriminately, 31 , 32,76 ; to be granted only at ammual Brewster Sessions, 36 ; certificates required from al'plicants for, 37 ; given to needy persons, 44 ; anmal renewal of, 46 ; filled np by Clerk of the leace, 47 ; increase in number of, $47,116-12 \%, 130$; withdrawal of. $50,53,68,69$, $70,71,73,74,80,85,95,97$, $98,100,101,103,108,136$, 141 ; restriction in granting of, recommented, 51, 53, 57, 101 ; for dran-sliops, 55, 57 ; allowed to lapse, 55,59 ; notice of apjlication for, required, 57 ; consent of Vestry required for granting of new, 63 ; fol jenewal of old, 64 ; conditions of granting new, in eity of london, it.; nonopoly in. condemned, 97 ; occusional, at fairs, 98-100 ; number of, in small boroughs, 103 ; in larger towns, 104 ; in provinces, 105 108 ; for sale of beer, 106,115 116 ; granted to respectable applicants, 132

Licensed houses, increase of, in London and Westminster, 39

Licensing, different aims of, 4 ; different forms of control, 5 ; first licensing act, $\overline{5}$; of taverns, 19 ; in Cambridge, 27 ; fees, 29 ; procednre regulated, 36 $38,55,113$; conditions of, enforced by Justices, 52-55, 59$62,72-73$; rules prescriber by Justices, 53, 54; conditions of, enforced by Vestries, 74-76; business relating to, discontimued at Quarter Sessions, 80 ; effects of increased stringency in, 88.89 ; in Tower Hanlets, 93-95; discretionary powers of Justices in, limiterl, 96, 133 ; change in policy of, 99 . 102 ; conditions of, not enforced, 102 ; restrictive policy of borough magistrates in, $103-104$

Lincoln, 144

Liquor, alcolrolic, consumption of, 82 ; sale of, to children, 134 ; mmicipalisation of traffic, 135 Liverpool, 104, 105, 116, 131, 132 Local option, instances of applica. tion of, $50,62,63.68,103$, 118,138

veto, See Local Option.

London, $16,18,21,22,33,36,39$, $40,64,72-79,87,90,1: 0,139$

London County Comncil, 135

London Magasine, 30

Lomslale, Eill of, 70

Lords, House of, 30-33, 123-124

Lotteries, 42

Macfarlane, Charles, 26

Malion, Lord, 26, 30

Maidstone (Kent), 56, 104 
Mainwaring, W., 40

Manchester, 60, 131; Court Leet Records of, 1

Manners, movement for the reformation of, 50-53, 96, 111

Societies for Reformation of, $137,138,140-143$

Manorial Court, 1

Mansfield, Lord, 8

Mariborough (Wilts), 90

Martinean, Harriet, 115

Mary, Queen, 147

Marylebone (Middlesex), 74,75

Massinger, 10

Meadley, George Wilson, 47

Melbourne, Lord, 125

Nerceron, Joseph, 94

Middlesex, 34, 35, 40, 41, 76, 77, $78,79,93,94,95,109,144$

Montgomery, R. M., 19

Monthly Review, 40.47

Morley (Devon), 106

"Mug-houses," 17

Municipal administration, 135

Municipal Corporation Commissioners (18:33-37), 46, 103

Inunicipalisation of liquor traftic, 135

Nundy, H. G., 123

Newbury (Berks), 89

Newcastle - on - Tyne (Northumberland), 59, 131

"Night-houses," 40, 46

Norfolk, 144, 150; pampllet by magistrate of, quoted, 56

Northamptonshire, 14.4

Nottinghamshire, $57-58,61$

Nourse, Timothy, 16

O'Connell, Daniel, 111

Owens, John, 19, 106

Oxford, 56

Oxfordshire, 56, 57, 61, 102

Paine, Tom, 144

Paley, Rev. William, D.D., 47

Parliament, Acts of. See Acts

Parliamentary IIistory quoted, 26, $2 \pi, 28,30$

Paterson, J., 19, 100, 130, 136
Pearson, John, 54

Penryn (Cornwall), 104

Petitions, from Distillers' Company, 22 ; from Middlesex Justices, 24: from distillers of Cambridge, 27

Pitchcombe (Somerset), 69

Place MISS., 23, 79, 128

Plymonth (Devon), 60, 71-72, 104

Plymouth Dock (Devon), 71

Poachers, 45

Police, 119, 140 ; Report of Committee on, in metropolis, 77 . $79,87,90,91,94,95-100$. 102

Police Act (1839), 130

Poutefract (Yorks), 142

Poor Law Inquiry Commissioners, 128

Poor Law, Old, 83

Poor rates increased, 148

Portsmouth (Hants), 104

Privy Conncil, circular letter to Mayors and Justices, 5, 11; "Orders" to Justices, 10, 13; proclamation issued by, 143 . See also Proclamation

"Priry searches," 141

Procedure of Justices in licensing codified, 113

Proclamation, Royal (1618), 7, 9, 12 ; (1787), 53, 59, 69, 143 ; intluence of, on policy of Justices, 56 ; societies formed to carry into execution, 138, $140,144,146$

Prohibition, impracticable in seven. teenth century, 2 ; of spirits, virtual, under Gin Act of $1736, \simeq 6,30$

Prostitutes, 40, 99, 139

Publicans, not to be appointed constables, 56 ; popular election of, 68 ; politics of, 86

Public-houses, reluction in number of, advocated, 57 ; suppression, $68-74$; number of, in Plymonth Dock, 71 ; in Tower Hamlets, 77 ; monopoly of, in hands of brewers, 89-93; unnecessary 
number of, 101 ; number of, in villages, 103 ; suppression of, 138 ; licences of, withdrawn,

141. See also Alehouses

"Punch houses," 21

Quarter Sessions, lieensing business discontinued at, 80 ; appeal to, permitted, 113

Quarterly Review, 101

Rates, Poor, 69

Reading (Berks), 90, 104

Recognisances, for good behaviour, 37,47 ; estreated, 56, 59

Refreshment-honses, wine licence to. 131

Register, Annual, 144

Regulation of liquor trade, origin of, 2 ; conflicting motives for, 3 ; of licensed honses negleeted by Jnstices, 16, 17, 33-36, 39, $40,41,47,51$; powers of, exereised by Justices, 49-50, $52-74,141,142$; Justices' policy of, condemned, 85, 111, 112 ; Justices' powers of, limited, 96 ; policy of, abandoned by Justices, 102 ; sale of beer without, 98.100; Justices' powers of, restored, 132 ; beer-shops brought under, 132. See also Licensing

Retailers, of wine, 19-20; of spirits, $21,25,29$; set up by brewers and distillers, 43. See also Spirits and Beer

Revenue, taxes on alcoholic drinks a souree of, 3 ; royal licences a source of, 19-20; duties on manufacture of spirits, 29 ; gin duty designed as means of, 32 ; Justices iufluencer by desire to increase, 42.43 ; from sale of beer, dlecrease in, 109

Rewarls, offered for information of sale of becr or spirits without lieence, 62

Ricardo, David, 93

Richardson, Judge, 13
Ripon (Yorks), 12, 104

Roeh, Thomas, 46

Rochester (Kent), 104

Rockingham, Marchioness of, 140

Rowntree, J., 134

Rugeley (Stafls), 99

S., Vicar of, in Kent, 40,45

St. Albans (Herts), 19

St. George's, Hanover Square, (Middlesex), 34

St. Giles-in-the-Fields (Middlesex), 39

St. Lnke's (Middlesex), 41

Salisbury, Bishop of (1743), 28, 31

Salisbury (Wilts), 57, 70

Samuelson, J., 26

Sanger, C. P., 135

Saxmundham (Suffolk), 62

Scarborough (Yorks), 104

Scarisbrick, Joseph, 18, 20, 110, 113

Secker, Archbishop, 30

Sheffield (Yorks), 70-71, 131

Sherwell, A., 134

Shops, sale of spirits in, 21-22 ; sale of beer in, 118; "off". licence for wine, 131

Shrewsbury (Salop), 17

Shropshire, 99

Signboards, 10

Sittingbourne (Kent), 19

Slaney, 111

Snith, Syduey, 111, 116

Smithfield, Fast (Tower IIamlets), 23

Smollett, Tobias, 23-24, 26, 39

Societies, parochial, for prosecution of felons, 141-142. See also Proclamation and Viee

Somerset, 13, 64, 69, 102, 144

Speen Division (Berks), 70

Spirits, distillation of, a monopoly, 20 ; free sale of, by distillers, 21 ; licences for retail sale of, $21,25,26,29,33,47,80,81$ 82,113 ; free sale of, in shops. 21.22 ; increased consumption of, $20,22,79,120$; statistics of cousumption of, $38,48,120$; 


\section{INDEX}

practical prohibition of retail sale of. 25 ; duties on mamufacture of, $27,29,52$; clanclestinely retailed, $28-29,34,36$, 39 ; licences for sale of, refused. 58 ; sale of, in Leeds, on Sum. days prohibited, 61 ; incitements to excessive use of, 78 ; sale of, discouraged in London, 78,79 ; sale of, in alehouses encouraged, 105

Stamford (Lincolnshire), 149

State Papers, calendar of, domestic, quoted, 12

Stipendiary magistrates in Middlesex, 77

Stockport (Cheshire), 60, 123

Strond (Glos.), 145

Suffolk, 57, 62, 66

Sunday, closing, 11, 40, 49-50, 55, $60,61,71,96,109,130,131$, $134,142,144$; rules relased, 123 ; sale of spirits on, prohibited in Leeds, 61 ; receiving of guests, stage-waggons, and carts on, prohibited, ib.

Suppression, of alehouses, $6,7,10$, 11-12, 13, 15; of taverns, 18. 19 ; of public-houses, 56,68 74 ; of dram-shops, 71 ; of disorderly houses, 138; .Justices' power of, repealerl, 113

Sureties for good behaviour of publicans, 56,57

Surety bonds, 47

Surrey, 55, $56,79,94,102,105,144$

Sussex, 102

Swaffling (Suffolk), 62

"Swankey shops," 115

Swillington (Yorkshire), 140

Sydney, Lord, 143

Tankersley (Yorks) 140

Taverus, definition of, 18 ; suppres. sion of, 1s; licensing of, 19 ; at St. Albans, 19

Tax, on alcoholic dirinks, a source of revenue, 3 ; on retailers of spirits, 25 ; on beer and cider withdrawu, 113
Temperance morement, 131

Temperance party, 86, 128, 1341.55

Thackleh, C. T., 128

Tiddlywinks, 116

Tied-house system, 8\$-93, 97

Tierl houses, number of, 91

Timberland, Ebenezer, 30

Tom and Jexry shops, 116

Tories, licensing policy of, 86, 111, 112

Tower Hamlets, 77, 94, 95, 100 , 139

Trading Justices, 76 . See also Justices of Middlesex

Transfer of licensed houses, procedure of, regulated, 36

Travellers, 11

Treaty Act (French), 131

Tuxford, 19

Twerton (Somerset), 67

Vagrants, harbouring of, 54 ; apprehension of, 141; "privy searches" for, 141

"Vested interests," 112

Vestries, rewarils offered by, 62 ; consent of, and condition of (1) granting new licences, 63 ;

(2) renewing licenees, 64; special meetings of, (1) for signing certificates of good character, $63 ;(2)$ for recommending the licensing and suppression of public-houses; regulation of public-houses by, $74-76$

Vestry, at Brighthelmstone, 63-64; proceedings of, at Wanstearl, 65 ; at Marylebone, 74,75

Veto, local. See Local Option

Vice, prevalent in public-houses, 39 ; encouraged by innkeepers, 52 : proclamation against Society for the Suppression of, $146^{\circ}$. See Proclamation

Victuallers, licensed, as constables, 56 ; in Westminster disqualified to be constables, ib.; agitatiou against Justiees by, 112 


\section{LIQUOR LICENSING IN ENGLAND}

Villages, public-houses in, 42, 44, $46,98 \cdot 100,102,103,116$, 117 ; licences not to be granted to public-houses on the outskirts of, 57 ; increase of Poor Rates in, 148 ; suppression of fairs in, $i b$. ; suppression of alehouses in, 149

Vintners, Comprany of, 19

"Wakes," 99, 149

Wales, 134

Walpole, Rt. Hon. Spencer, 115

Walpole, Sir Robert, 27, 29, 30

Walter, Chief Baron, 13

Walton (Essex), 62

Wanstead (Essex), 65

Wellington, Duke of, 113, 115

West Looe (Cornwall), 104

West, Symbolaography by, referred to, 7

Westminster, 21, 22, 39, 40, 41, 56 ; Burgess Court of, 40, 41 ; St. James's, 72, 73 ; pamphlet by Inhabitant of, 41

Weston, Rev. Mr., 145

Weston (Somerset), 69
Widcomb (Somerset), 69

Wilberforce, William, 50, 53, 142144,147

Wilson, Walter, 20

Wiltsline, 57, 70, 124

Wine, licences to sell, given to tavern-keepers, 19 ; privilege of Vintners' Company to sell without licence, 19 ; retailers of, required to be licensed victuallers, 19.20

Wine-shops, 18, 131

Winskill, P. T., 115, 116, 131, 132

Woodbridge (Suffolli), $66^{\circ}$

Woolstock (Oxfordshire), 45

Woolward, Josiah, 138

Worth, R. N., 71

Wyndham, Rt. Hon. Wm., 87

Yorkshire, North Riding of, 66, 144

West Riding of, $53,57,66,67$, $70,71,140,142$

Yoxall (Staffordshire), 103

Zouch, liev. Henry, 50, 140, 141 149

THE END

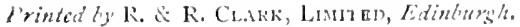


Will be mublished in 1904, by the Same Authors.

\section{ENGLISH LOCAL GOVERNMENT (THE OLD ORDER)}

BY SIDNEY AND BEATRICE WEBB

\section{ADVERTISEMENT}

'THIS work, which represents the fruits of six years' investiga1 tion into every part of English Local Government, will deal with its development between 1700 and 1835. Avoiding discussion as to the origins of English local institutions, or eren as to their growth during the Middle Ages, it will describe, in vivid detail, the development of strueture anl function during the eighteenth century, which led to the reforms of 1832-35, and on which the existing system of Local Govermment in England is basel.

This description, combining in one narrative both history and philosophical analysis, is framed upon new lines and drawn almost entirely from materials hitherto unused. Instead of dealing principally with the law of local government, and the successive changes in the statute-look, the anthors describe these institutions, in structure and function, as vital social tissue, of which statute and case law form but one of many canses. The subject-matter is, in fact, not law or politics, but the lifehistory of the varions species of local governing borlies. An attempt is made to set forth, from mannscript minutes and otler unpublished material, controversial pamphlets and local newspapers, and all other contemporary sources, the way in which the actual administration was carried on, the manner in which it was affected by contemporary ideas and other influences, and its result on the health and cliaracter of the nation. 


\title{
CONTENTS
}

\author{
PART I \\ Local Governaent Structure
}

CAAF.

I. The Open Vestry.

II. The Select Vestry.

III. The Statutory Body.

(a) Incorporated Guardians of the Poor.

(b) Improvement Commissioners.

IV. The County Justices.

$V$. The Municipal Corpolation.

VI. The Court Leet.

VII. The Commissioners of Seweis.

\section{PART II}

\section{Local Government Fonction}

Chaf.

I. The Relief of Destitution.

A. The Working of the Old Poor Law.

(i) Doles and Pensions.

(ii) 'The Allowance System.

(iii) Finding Wagres for the Unemployed.

(iv) Ontuloor Employment of the Poor.

(v) Apprenticeslip.

(vi) The Poorhouse.

(vii) The Workhouse.

(a) As a Device for profitably employing the Poor.

(b) As House of Correetion.

(c) As a Deterrent.

(d) $\Lambda$ s Asylum for the Impotent.

(e) As a nieans of applying the 'Test by Regimen.

(f) $\Lambda$ s a place of specialised institutional treatment.

(viii) The Contract System.

(a) Farming the Whole I'oor.

(b) Farming the Workhouse.

(c) Contracting for Children.

(d) Contracting for Lunaties.

(e) Contracting for Medical Relief.

(ix) Settlement and Liemoval.

(x) Allowanees for Bastardy. 


\section{ENGLISH LOCAL GOVERNMENT-Continued.}

CHAP.

I. The Relief of Destitution.

B. The Ineptitude of the Old Poor Law.

(i) The Canons of Poor Law Effieiency.

(ii) The Agel.

(iii) The Sick.

(iv) The Infants and Minors.

(v) The Able-bodied.

(vi) Destitution and Crime.

(vii) The Partial Destitution of the Parasitic Trades.

(viii) The Poor Law as a Triad.

(ix) The Mobility of Labour.

(x) Conelusion.

II. The Regulation of Personal Conduct.

(a) The Repression of Vagraney.

(b) The Prevention of Crime and Disorder.

(c) The Maintenance of Prisons.

(d) The Regulation of Trale.

(i) Licensing.

(ii) Standard Conditions of Employment.

(iii) Maximum Price.

(iv) Determinateness of the Bargain.

(e) The Suppression of Nuisances.

(f) A Carnival of Self-Will.

III. Municipal ENTERPRise.
(a) Churches.
(b) Roads.
(c) Bridges.
(d) Harbours.
(e) Markets.
(f) Town Improvement.
(g) Neglected Services.

IV. LOCAL Finaxce.

(a) Public Property.

(b) Customs anid Tolls.

(c) Assessment and liating.

(d) Lapsed sources of Incone.

\section{PAR'T III}

Local Government Theory

CHAP.

I. The Interaction of Siructure and Function.

II. Conchusion.

LONGMANS, GREEN AND CO., LONDON, NEW YORK, AND BOMBAY 


\section{DY THE SAME AUTHORS.}

"A permanent and invaluable contribution to the sum of human knowledge. . . We commend to the pullic a book which is a monument of research and full of randour. . . Indispensable to erary lublicist and politician."-TIMES, 4th fammary $189 \mathrm{~s}$ (day of publicutions).

Fifth Thousand. Now and Cheaper Edition, 1902, with additional. chapter. Tro volumes bound in one. l'ost 8 ro, lirii. and $929 \mathrm{mp}$., with Two Diugrems.

Irice 12 s. 6d. net.

\section{INDUSTRIAL DENOCRACY}

\section{BY SIDNEY AND BEATRICE WEBB}

\section{ADVERTISEMENT}

$1 \mathrm{~N}$ this work the anthors of "The History of Trade Unionism" deal, not with the past, bnt with the present. They describe, with the systematic letail of the scientific observer, and in the same oljective spirit, all the forms of Trade Unionism, Factory Legislation, and other regulations of industry to be found in the British Isles. The whole structure anct function of Labour Organiwation and Restrietive Legislation in every industry is analysed aml criticised in a manner never before attempted. The employer in difliculties with his workmen, the trale unionist confronted with a fresh assault upon his standard rate, the politician tronbler abont a new project for Factory Legislation, the public-spirited citizen concerned as to the real issues of a labour dispute, will find eluchlated in this work the very problems on which they are thinking. It is a storehonse of anthenticated facts about every branch of the "Labour Question," gathered from six years' personal investigation into every industry in all parts of the kingdom; systematically classified and made accessible by an umusually eliborate Intex. 


\section{INDUSTRIAL DENIOCRACY_Continued.}

But the Book is more than an Encyclopedia on the Labour Qnestion. Scientific examination of tracle union structure reveals, in these thousand self-governing republics, a remarkable evolution in democratic constitutions, which throws light on political problems in a larger sphere. The century-long experience of these working-class organisations affords unique evidence as to the actual working of such experlients as the Referendum, the Initiative, Government by Mass Meeting, Anmual Flections, Proportional Representation, Payment of Members, and, generally, the relation between the Citizen-elector, the chosen Representative, and the Executive Officer. The intricate relations of trade with trade have an interesting bearing upon such problems as Local Govermment, Feleration, and Home Rule. Those who regard the participation of a working-class electorate in the affairs of govermment as the listinctive, if not the dangerous, feature in molern politics, will here find the phenomenon isolated, and may learn how the British workman actually deals with similar issues in his own sphere.

In a long additional chapter to the 1902 edition, the anthors describe the changes in Trade Unionism and its enviroument since 1894, the various legal decisions which have been given and their probable outcome, together with some indication of their effect on Trade Union opinion. A careful description is also given of the development of New Zealand, Victorian, and New Sonth Wales legislation of the nature of Compulsory Arbitration, the "Common Rule" and the "Legal Minimum Wage."

The analysis of the working of Trade Unionism and Factory Legislation in the various industries of the United Kingdom has involved a reconsideration of the conclusions of Political Economy. The anthors give a new and original description of the working of industrial competition in the business world of to-day; and 


\section{INDUSTRIAL DEMOCRACY_Continued.}

they are led to important modifications of the views currently hell upon Capital, Interest, Profits, Wages, Women's Labour, the Population Question, Foreign Competition, Free Trade, etc. The latter part of the work is, in fact, a treatise upon Economics.

Finally, it should be stated that the authors, in the Preface, describing their investigations, propound a new view as to the scope and method of Political Science.

\section{CONTENTS}

Preface to the ig02 Enition.

\section{PART I \\ Trade Union Strccture}

CHAP.

I. Primithre Democract.

II. Representative Institutions.

III. The Unit of Goverimente

1Y. IntFrunion RFlations.

\section{PART II}

r'Hat.

\section{Trade Union Function}

I. The Method of Mutual Insuraxce.

II. 'The Methot) of Collective Babchanisa.

III. Arbitration.

IV. The Metion of Legal Exactmant.

V. The Standard Rate.

VI. 'Tine Nolimal inay.

VII. Sanitition ANI Safery.

VIII. New Processes and Machinery.

IX. Continutity of Employment.

x. The Extrance to a Trade.

(a) Aplrenticeship.

(b) The Limitation of Boy-Labour.

(c) Progression within the Trade.

(d) The Exclusion of Wonen.

XI. The Rueit tu a Tliand.

XII. THe Injlications of Trane Unionism.

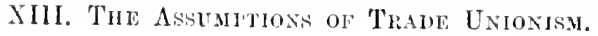




\section{INDUSTRIAL DEMOCRACY_-Continued.}

PART III

\section{Trade Union Theori}

CBAP.

I. The Verdict of the Economists.

II. The Higglisg of the MARET.

III. The Ecoxomic Characteristics of Trade UNroxisy.

(a) The Device of liestriction of Numbers.

(b) The Derice of the Common Rule.

(c) The Effect of the Sectional Application of the Common Rule on the Distribution of Industry.

(d) Parasitic Trates.

(e) The National Minimum.

(f) The Unemployable.

(g) Summary of the Economic Characteristics of the Device of the Common Rule.

(h) Trade Uniou Methorls.

IV. Trade Unionisy and Demochact.

\section{APPENDICES}

I. The legal Positiox of Collective Pargating ix Exglanid.

II. The Brarigg of Ixdestrial Parantiga ayd the Policy or a National Minmey ux the Free Trade Coxtroversy. III. Some Statistics bearixg ox the Relative Moyements of the Marrage axd Birtil Rates, Patperism, Wages, axi the Price of Winat.

IV. A Supplemext to the biblograpiy of thane l niosisy. INDEx.

LONGMANS, GREEN AND CO., LONDON, NEW YORK, AND BOMBAY 
OTHER WORKS II THE SAME AUTHORS.

\section{Sixth ThuUsand}

\section{THE \\ HISTORY OF TRADE UNIONISM}

BY SIDNET AND BEATRICE WEEB

New Edition, 1902. Revised, with alditional chapter.

Tost Svo, 547 pp., Cloth, with Coloured Map.

Price 7s. 6ol. net.

"A masterly piece of work."-Times.

"To the politician . . a an invahnable guide."-Observer.

\section{CONTENTS}

Preface.

Preface to the 1902 Edition.

Chap. I. The Origins of Trutle Unionism.

Chap. If. The Struggle for Existence (1799-1825).

Cinaf. III. The Revolutionary Periol (1829-1842).

Chap. IT. The New Spirit and the New Morlel (1843-1860).

Chal. Y. The Junta and their Allies (1860-1875).

(HaP. TI. Sectional beveluments (1863-1885).

Cras. IrIT. The Old Unionism and the New (1875-1889).

Chap. VIII. The Trule Union Worlu (1892-1894).

hlap of Trade Unionisis.

Applandix,-On the Assmed Comnection between the Trade

Unions and the Gilds in Dublin_-Sliding ScalesThe Summons to the First Trate Union CongressDistribution of Trade Unionists in the United KingdomThe Progress in Membership of particular Trade UnionsList of Publicitions on Trade Unions and Combinations of Itorkmen.

INDEX.

LONGMANS, GREEX AND CO, LONDON, NEW YORL, AND BOMBAY 
OTHER WORKS BY THE SAME AUTHORS.

\section{PROBLEMS OF MODERN INDUSTRY}

\section{By SIDNEY AND BEATRICE WEBB}

New Edition, 1902 , with additional chapter. Post 8vo, 286 pp. Price 6s. net.

\section{CONTENTS}

Preface.

Preface to the 1902 Edition.

Chap. I. The Diary of an Investigation. By B. W.

Crap. II. The Jews of East London. By P. IT.

C'gap. III. Women's Wages. By S. W.

Chap. IV. Women and the Factory Acts. By B. W.

Chap. V. The Regulation of the Hours of Labour. By S. W.

Снар. VI. How to do away with the Sweating System. By B.W.

Char. VII. The Reform of the Poor Law. By S. W.

Char. VIII. The Relationship between Co-operation and Trude Unionism. By B. Wr.

Chap. 1X. The National Dividend and its Distribution. By S. W.

Char. X. The Difficulties of Individnalism. By S. Wr.

Char. XI. Socialism True and False. By S. W.

INDEX.

LONGMANS, GREEN AND CO., LONDON, NEW YORK, AND BOMBAY 
OTHER WORKS BY THE SAME AUTHORS.

PUblished by GRANT RICHARDS.

Second Edition. Fourth Thousand. 8vo, wvi. and $234 \mathrm{pp}$. Price $1 \mathrm{s.}$

\section{THE}

\section{CASE FOR THE FACTORY ACTS}

Edited by Mrs. Sidney Webb. With a Preface by Mrs. Humphrey Ward.

\section{CONTENTS}

Preface. By Mlrs. Humpurey Ward.

Char. I. The Economics of Factory Legislation. By Mrs. SIDNEY WEB].

Chap. II. The Historical Development of the Factory Acts. By Miss B. L. Hutchins.

Cuap. III. The More Obvions Defects in our Factory Corle. By Miss Gertrude Tuckweil.

Cuap. IV. Colonial Developments in Factory Legislation. By Mrs. W. P. Rewes.

Criar. I. Some Current Objections to Factory Legislation for Women. By Miss Clementina Black.

Apjendix. Books Recommended. Index.

\section{LABOUR IN THE LONGEST REIGN, 1837:1897.}

By Sinney Webr, LL.B. Small Svo, Cloth. Price 1s. 


\section{Published BY SWAN SONNENSCHEIN AND CO.}

\section{THE CO-OPERATIVE MOVEMENT IN GREAT} BRITAIN. By Beatrice Potter (Mrs. Sidney Webb). Second Edition, 1893. Crown 8vo, with Coloured Map showing Distribution of the Co-operative Movement, Appendices, and Index. Price 2s. 6d.

"Miss Beatrice Potter's Imminous and suguestive volume is not a mere bald, historical outline, but a thoughtful and pregnant study of tendencies, causes, and effects."-Times.

"The whole volume is full of suggestion, hoth to co-operators and politicians. . . It is without doutit the ablest and most philosophical analysis of the co-operative movement which has yet been produced." Speatier.

SOCIALISM IN ENGLAND. By SidNeY Webi, LL.B. Second Edition, 1893. With new Introductory Chapter. Crown 8vo. Price 2s. 6d.

"The best general view of the subject from the moderate Socialist side."-Athenaum.

THE LONDON PROGRAMME. By SIDNEY Webe, LL.B. Second Edition, 1894. With new Int roductory Chapter. Crown 8 ro. Price 2s. 6d.

"Brimful of excellent ideas."-Anti.Jacobin.

\section{PUBLISHED BY WALTER SCOTT.}

THE EIGHT-HOURS DAY. By SIDNEY WEBH, LL.B. and HAROLD Cox, B.A. Crown 8 vo, 280 ple, with Bibliography. Paper Covers. Price 1s.

"The unique value of this little book lies in its collection of facts. It is likely, for some time, to hold the field as the handlook to one of the ehief items in the social politics of the immediate future."Pall Meall Gazette.

Published by VANDENHOEK UND RUPRECHT (Göttingen)

DER SOCIALISMUS IN ENGLAND. Geschildert von Englischen Socialisten. Herausgegeben von Sidney Wrbb. 


\title{
STUDIES IN
}

\section{ECONOMICS AND POLITICAL SCIENCE}

A series of Monographs by Lecturers and Stulents connected with the London School of Economics and Politicul Science.

EDITED BY

Professor W. A. S. HEWINS, M.A.,

DIRECTOR OF THE LONDON SCHOOL OF ECONOMICS AND POLITICAL SCIENCE.

\author{
Published by \\ P. S. KING AND SON,
}

ORCHARD HOUSE, 2 AND 4 GREAT SMITH STREET, WESTMINSTER.

1. The History of Local Rates in England. The substance of Five Lectures given at the School in November and December 1895. By Edwin Cannan, M.A., LL.D. 1896. 140 pp., Crown 8 vo, Cloth. 2s. 6d.

2. Select Documents Illustrating the History of Trade Unionism. I.-The Talloring Traue. By F. W. Galton. With a Preface by Sidexey $\mathbb{W e b B , ~ L L . l ; , ~ 1 8 9 6 . ~} 242$ pl., Crown 8vo, Cloth. 5 s.

3. German Social Democracy. Six Leetures delivered at the School in February and Mareh 1596. By the Hon. Bertranu liussell, B.A., late Fellow of Trinity College, Cambrilge. With an Aplendix on Social Democracy and the Woman Question in Germany by Alys Russeld, B.A. 1896. 204 pl', Crown Svo, Cloth. 3s. $6 \mathrm{~d}$.

4. The Referendum in Switzerland. By M. Srmon Deplorge, University of Lonvain. With a Letter on the Referendum in Belgim by M. J. VAN DEN HeUvel, Professor of International Law in the University of Lonvain. Translaterl by C. P. TreVwlyan, M.A., Trinity College, Cambridge, and edited with Notes, Introduction, bibliography, and Aprentices, by LiLlaN Toms, of Girton College, Camlridge, Research Student at the School. 1898. x. aud 334 ll1., Crown 8vo, Cloth. 7s. 6ul.

5. The Economic Policy of Colbert. By A. J. SArgent, M.A., Senior Ifulme Exhilitioner, Brazenose College, Oxford; and Whateley F'rizeman, T'rinity College, 1)ubliu, 1897. 1899. viii. and 138 1']., Crown 8vo, Cloth. 2s. 6ul.

6. Local Variations in Wages. (The Arlam Smith Prize, Cambridge University, 1898.) By F. W. LAwnence, M.A., Fellow of Trinity College, Cambridge. 1899, viii. and $90 \mathrm{pl}$., with Index and 18 Maps and Diagrams. Quarto, 11 in. by $8 \frac{1}{2}$ in., Cloth. 8s. 6d. (Published hy Longmans, fireen and Co., 39 Paternoster Row, Lonlon.) 



\section{UNIVERSITY OF CALIFORNIA LIBRARY}

\section{Los Angeles}

This book is DUE on the last date stamped below. 


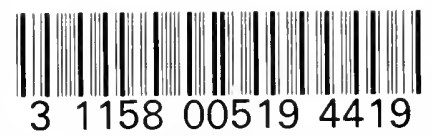

$\therefore$ atos -

UC SOUTHERN REGIONAL LIBRARY FACILITY

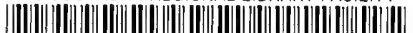
|I|||||||||||||||||||||||||||||||||||||||||||||||||||||||||||| AA $001001445 \quad 4$ 
